FÁBIO BOMFIM MEDEIROS

ANÁLISE DA ADEQUAÇÃO DOS PROGRAMAS DE FINANCIAMENTO HABITACIONAL PARA ATENDER AS NECESSIDADES DE AQUISIÇÃO DE MORADIAS ADEQUADAS DA POPULAÇÃO DE BAIXA RENDA NO BRASIL 
FÁBIO BOMFIM MEDEIROS

\title{
ANÁLISE DA ADEQUAÇÃO DOS PROGRAMAS DE FINANCIAMENTO HABITACIONAL PARA ATENDER AS NECESSIDADES DE AQUISIÇÃO DE MORADIAS ADEQUADAS DA POPULAÇÃO DE BAIXA RENDA NO BRASIL
}

\author{
Dissertação apresentada à Escola \\ Politécnica da Universidade de São Paulo \\ para obtenção do Título de Mestre em \\ Engenharia.
}

SÃO PAULO 
FÁBIO BOMFIM MEDEIROS

\title{
ANÁLISE DA ADEQUAÇÃO DOS PROGRAMAS DE FINANCIAMENTO HABITACIONAL PARA ATENDER AS NECESSIDADES DE AQUISIÇÃO DE MORADIAS ADEQUADAS DA POPULAÇÃO DE BAIXA RENDA NO BRASIL
}

\author{
Dissertação apresentada à Escola \\ Politécnica da Universidade de São Paulo \\ para obtenção do Título de Mestre em \\ Engenharia \\ Área de Concentração: \\ Engenharia de Construção Civil e Urbana \\ Orientador: \\ Profa. Doutora Eliane Monetti
}

SÃO PAULO 
Este exemplar foi revisado e alterado em relação à versão original, sob responsabilidade única do autor e com a anuência de seu orientador.

São Paulo, 17 de Agosto de 2007.

Assinatura do autor

Assinatura do orientador

\section{FICHA CATALOGRÁFICA}

Medeiros, Fábio Bomfim

Análise da adequação dos programas de financiamento habitacional para atender as necessidades de aquisição de moradias adequadas da população de baixa renda no Brasil / F.B. Medeiros. -- ed. rev. -- São Paulo, 2007.

$129 \mathrm{p}$.

Dissertação (Mestrado) - Escola Politécnica da Universidade de São Paulo. Departamento de Engenharia de Construção Civil.

1.Financiamento da habitação 2.Baixa-renda - Brasil I.Universidade de São Paulo. Escola Politécnica. Departamento de Engenharia de Construção Civil II. t. 


\section{DEDICATÓRIA}

Dedico este trabalho aos meus pais, Xisto Medeiros e Helena Bomfim, pelo exemplo, dedicação e apoio incondicional. 


\section{AGRADECIMENTOS}

À minha orientadora Profa. Dra. Eliane Monetti, por todo o suporte e compreensão no desenvolvimento deste trabalho.

À Lizandra Soave, companheira e amiga, pelo apoio e compreensão nos momentos de minha ausência.

Ao amigo Daniel Gutierrez, por toda a ajuda e conselhos.

Ao amigo Paulo Sebastião, pela paciência e cooperação.

A todos que, direta ou indiretamente, colaboraram nesta pesquisa. 


\section{RESUMO}

A migração acentuada para áreas urbanas e o rápido crescimento da população nas últimas décadas criaram forte demanda por habitações no Brasil e, como conseqüência, o aparecimento de graves problemas urbanos, com o aumento das necessidades habitacionais da população, principalmente no segmento de baixa renda. Uma das razões do não-atendimento dessa demanda é a dificuldade de acesso da população a habitações adequadas no setor formal. O presente trabalho fará uma análise da adequação dos programas de financiamento habitacional voltados à população de baixa renda, à luz das necessidades e limitações dessa população, visando a dar subsídios à elaboração e estruturação de programas de financiamento habitacional que possam melhorar o acesso da população de baixa renda a habitações adequadas.

O texto inicialmente preocupa-se em discutir as características da população de baixa renda, como suas necessidades habitacionais, orçamento familiar e capacidade de pagar o preço da menor habitação adequada. Posteriormente, apresenta e analisa os principais programas de financiamento habitacional voltados à população de baixa renda no Brasil, discutindo seus objetivos, fontes de recursos e principais características. Por fim, o trabalho discute a adequação desses financiamentos às necessidades da população de baixa renda, seja quanto à sua capacidade de pagamento, seja quanto ao volume de recursos necessários para atender à sua demanda para aquisição de habitações adequadas, mostrando onde existem desajustes que interferem no acesso dessa população a habitações adequadas no setor formal e sugerindo realinhamentos na estruturação dos programas e no volume de recursos ofertados. 


\begin{abstract}
The accentuated migration to urban areas and the rapid population growth in the last decades have created strong demand for housing in Brazil and, as consequence, the appearance of serious urban problems, with an increase in the number of housing necessities, mainly in the segment of the low-income population. One of the reasons for the existence of non-attended demand is the low-income population difficulty in accessing adequate housing units in the formal market. The present dissertation will analyze the adequacy of the housing finance programs directed to low-income households, in the light of their necessities and limitations, aiming to give subsidies for the development and structuration of housing finance programs that could improve the access of the low-income population to adequate housing units.
\end{abstract}

The dissertation initially discusses the characteristics of the low-income population, such as their housing necessities, familiar budget and capacity to pay the price for the smallest adequate housing unit. Later, it presents and analyzes the main housing finance programs directed to the low-income population in Brazil, discussing their objectives, sources of funds and main characteristics. Finally, the dissertation discusses the adequacy of these housing finance programs to meet the necessities of the low-income population, both in relation to their payment capacity and to the volume of resources to attend their demand for purchasing adequate housing units, showing where it is disadjusted in a way that interferes in the access of this population to adequate housing units in the formal market and suggesting realignments in the structuration of these programs and in the volume of the offered resources. 


\section{SUMÁRIO}

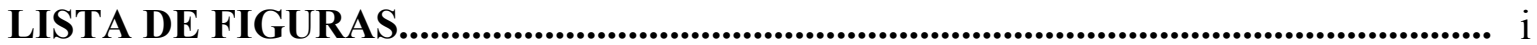

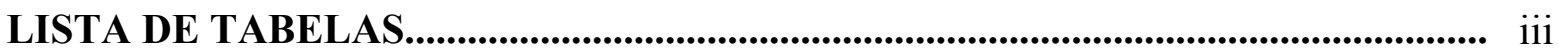

LISTA DE ABREVIATURAS E SIGLAS............................................................. iv

1 INTRODUÇÃ

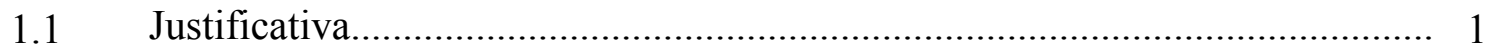

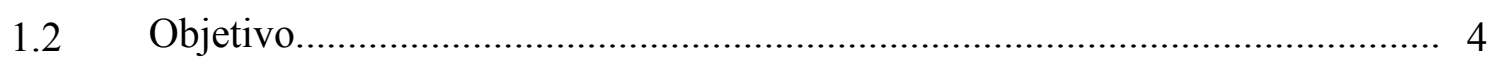

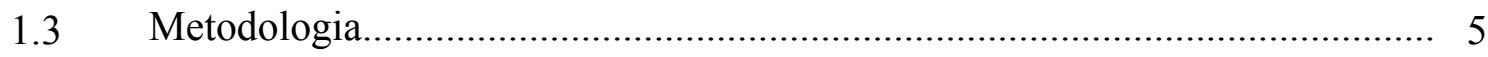

2 НАВІТАС̆А̃̃

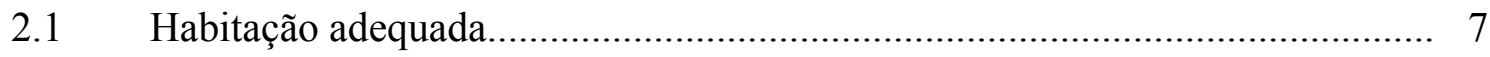

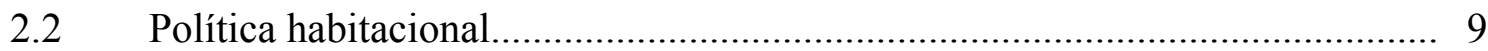

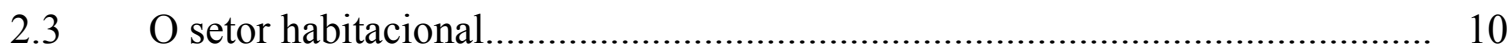

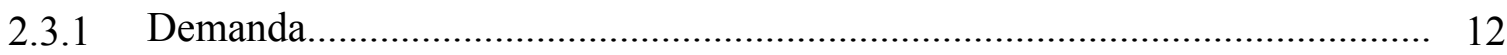

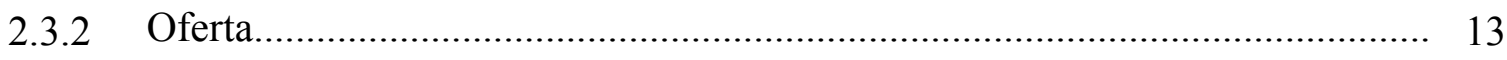

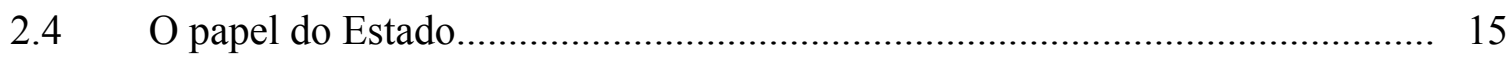

2.5 Subsídios para o acesso à habitação.......................................................... 17

3 O PROBLEMA DA AQUISIÇÃO DE HABITAÇÕES ADEQUADAS PELA POPULAÇÃO DE BAIXA RENDA.................................................................... 23

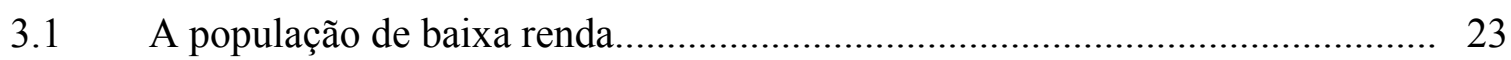

3.2 As necessidades habitacionais da população de baixa renda............................ 25

3.3 O crescimento do número de famílias de baixa renda................................... 32

3.4 As necessidades habitacionais e a demanda efetiva por habitações................. 33

3.5 O orçamento familiar e a parcela do rendimento destinada à habitação............ 34

3.6 Análise da capacidade da população de baixa renda em pagar o preço da

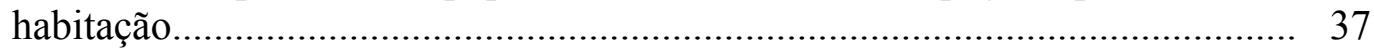

3.6.1 A origem dos rendimentos......................................................................... 37

3.6.2 O descolamento entre a evolução do rendimento e o crescimento dos preços da habitação................................................................................................ 37

3.6.3 A evolução da distribuição das despesas familiares da população de baixa renda.......................................................................................... 39

3.6.4 A capacidade da população de baixa renda de pagar o preço da habitação....... 43

4 PROGRAMAS DE FINANCIAMENTO HABITACIONAL VOLTADOS À POPULAÇÃO DE BAIXA RENDA NO BRASIL................................................ 46

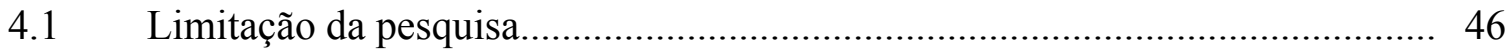

4.2 Histórico dos programas de financiamento habitacional no Brasil................... 47

4.2.1 Auge e declínio do Sistema Financeiro de Habitação - SFH

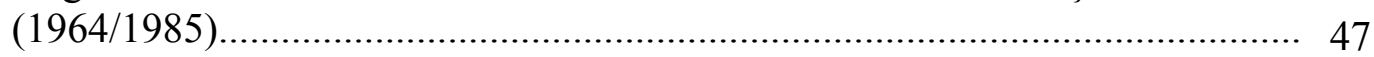

4.2.1.1 Criação e estruturação do SFH.................................................................... 47 
4.2.1.2 O funcionamento do SFH no período 1964/1985

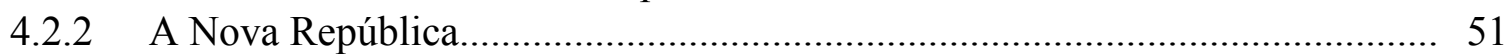

4.2.3 O Período Pré-Plano Real................................................................................. 53

4.2.4 O Período Pós-Plano Real..................................................................... 54

4.3 As principais fontes de recursos dos programas de financiamento habitacional no Brasil - FGTS e SBPE......................................................... 56

4.3.1 O FGTS - Fundo de Garantia do Tempo de Serviço......................................... 56

4.3.2 O SBPE - Sistema Brasileiro de Poupança e Empréstimo................................ 63

4.4 Aspectos da Política Nacional de Habitação brasileira voltados ao

4.5 Programas federais para o financiamento habitacional da população de baixa

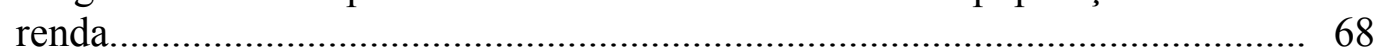

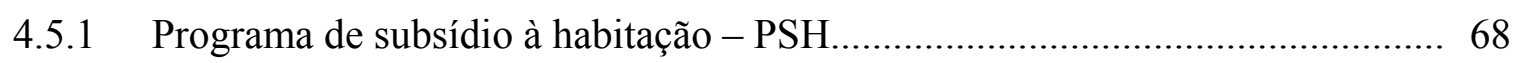

4.5.2 Carta de crédito individual - FGTS....................................................... 70

4.5.3 Carta de crédito associativa - FGTS............................................................ 72

4.5.4 Programa de arrendamento residencial - PAR ............................................. 74

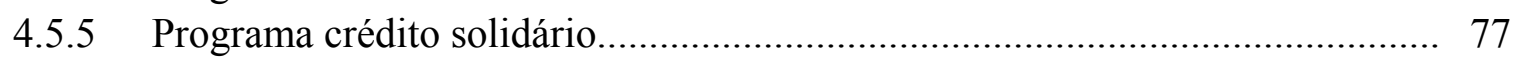

4.5.6 Programas Habitar-Brasil e Pró-Moradia...................................................... 78

4.5.7 Resumo dos programas federais para o financiamento/arrendamento habitacional da população de baixa renda................................................... 79

\section{DISCUSSÃO}

5.1 Os principais programas de financiamento habitacional atualmente ofertados no Brasil e a população de baixa renda.

5.1.1 Os financiamentos habitacionais e a capacidade de pagamento da população de baixa renda..................................................................................... 80

5.1.2 Habitação popular referência - HPR........................................................ 82

5.1.3 Programas Carta de Crédito Individual e Associativa...................................... 83

5.1.4 Programa de Arrendamento Residencial - PAR............................................ 86

5.1.5 Programa de Subsídio à Habitação - PSH...................................................... 88

5.1.6 Programa Crédito Solidário....................................................................... 89

5.2 As exigências de crédito dos financiamentos habitacionais e a população de baixa renda..

5.3 A demanda reprimida para a aquisição de moradias adequadas e o número de

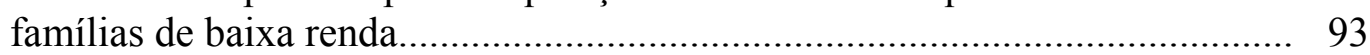

5.4 O volume de recursos utilizados e as famílias atendidas................................. 95

5.5 Eficiência na utilização dos recursos alocados............................................. 98

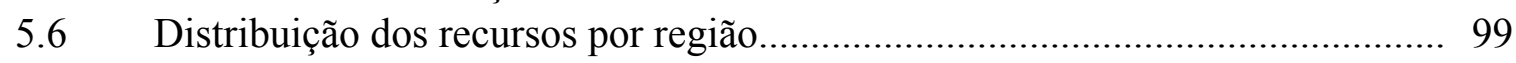

5.7 Estimativa da necessidade de ampliação do volume de recursos ofertados pelo Governo Federal para atender a população de baixa renda...................... 100

5.7.1 Primeira hipótese: atendimento da população de baixa renda pela aquisição da menor habitação popular.................................................................... 105

5.7.2 Segunda hipótese: atendimento da população de baixa renda pela aquisição de moradias e financiamentos parciais. 
5.8 Considerações finais sobre a adequação dos programas federais de financiamento habitacional................................................................... 112

6 CONCLUSÃO

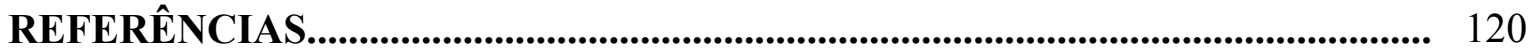




\section{LISTA DE FIGURAS}

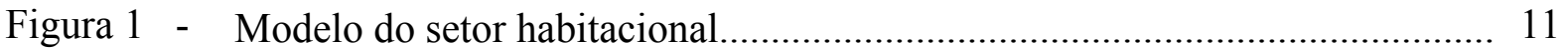

Figura 2 - Gráfico da distribuição do déficit habitacional total no Brasil.................................. 27

Figura 3 - Gráfico da distribuição de famílias, famílias de baixa renda e déficit habitacional no Brasil, por regiões.

Figura 4 - Gráfico da distribuição do número de inadequações habitacionais da população de baixa renda no Brasil.

Figura 5 - Gráfico da relação entre a inadequação habitacional da população de baixa renda e a inadequação habitacional total.

Figura 6 - Gráfico da distribuição dos tipos de inadequação habitacional da população de baixa renda, por região.

Figura 7 - Gráfico da evolução do número de famílias no Brasil, por faixas de renda...

Figura 8 - Gráfico do percentual do rendimento familiar destinado à habitação, por classes de rendimento no Brasil

Figura 9 - Gráfico da origem dos rendimentos monetários, por classes de rendimento.............. 37

Figura 10 - Gráfico da evolução do salário mínimo, INCC e INPC .............................................. 38

Figura 11 - Gráfico da parcela do orçamento familiar destinada à habitação pela população de baixa renda - 1995/1996 e 2002/2003.

Figura 12 - Gráfico da evolução do rendimento familiar destinado à habitação, por tipo de utilização - 1995/1996 e 2002/2003

Figura 13 - Gráfico da parcela do orçamento familiar destinada à habitação pela população de baixa renda, por região - 2002/2003.

Figura 14 - Gráfico do percentual de rendimento derivado para o crescimento patrimonial

Figura 15 - Juros máximos suportados para o financiamento habitacional na aquisição da habitação popular referência, por faixa de renda.

Figura 16 - Fluxo de recursos do FGTS

Figura 17 - Número de financiamentos habitacionais no âmbito do SFH......

Figura 18 - Gráfico da estimativa dos descontos (subsídios diretos) com recursos do FGTS, por faixa de renda

Figura 19 - Gráfico da capacidade de tomar financiamentos habitacionais e subsídios diretos da população de baixa renda, em relação à HPR

Figura 20 - Gráfico da evolução da DRAMA absoluta da população de baixa renda, entre 2000 e 2005

Figura 21 - Gráfico da evolução da DRAMA relativa da população de baixa renda, entre 2000 e 2005 ......

Figura 22 - Gráfico da evolução dos recursos federais utilizados no financiamento/arrendamento e em subsídios diretos para habitação popular

Figura 23 - Gráfico do número de habitações populares financiadas/arrendadas com recursos Federais

Figura 24 - Gráfico das parcelas utilizadas dos recursos alocados para financiamento/arrendamento da habitação popular, em 2004 e 2005.

Figura 25 - Gráfico da distribuição dos recursos do FGTS utilizados e da DRMA das famílias de baixa renda, entre 2003 e 2005 , por região. 
Figura 26 - Gráfico da participação dos programas federais no atendimento ao crescimento do número de famílias de baixa renda no Brasil....

Figura 27 - Gráfico da projeção do número de famílias de baixa renda até 2015 ..

Figura 28 - Gráfico da projeção do volume anual de recursos necessários para atender tanto a parcela considerada do crescimento quanto a DRAMA das famílias de baixa renda, na aquisição da menor habitação popular.

Figura 29 - Gráfico da distribuição, por tipo, da projeção anual de recursos necessários para atender tanto a parcela considerada do crescimento quanto a DRAMA das famílias de baixa renda.

Figura 30 - Gráfico da distribuição, por região, da projeção do volume anual de recursos necessários para atender tanto a parcela considerada do crescimento quanto a DRAMA das famílias de baixa renda.

Figura 31 - Gráfico da projeção do volume anual de recursos necessários para atender tanto a parcela considerada do crescimento quanto a DRAMA da população de baixa renda, com base no valor médio dos financiamentos concedidos em 2005 


\section{LISTA DE TABELAS}

Tabela 1 - Crescimento populacional e urbano no Brasil............................................ 24

Tabela 2 - Distribuição da população por faixas de renda no Brasil.............................. 25

Tabela 3 - Distribuição do orçamento familiar da população de baixa renda................ 34

Tabela 4 - Número de financiamentos habitacionais concedidos pelo Sistema Financeiro da Habitação no período de 1964 a 1986, em milhares de moradias.

Tabela 5 - Limites para financiamentos habitacionais com recursos do FGTS............... 60

Tabela 6 - Metas e Resultados Físicos e Financeiros do FGTS - 2005........................ 62

Tabela 7 - Taxas de acompanhamento de operação........................................................ 71

Tabela 8 - Valor máximo de aquisição de unidades habitacionais para arrendamento

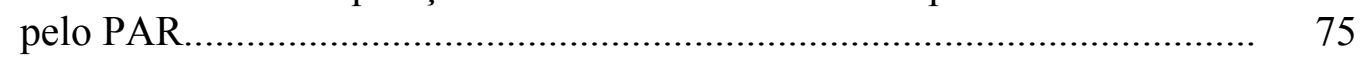

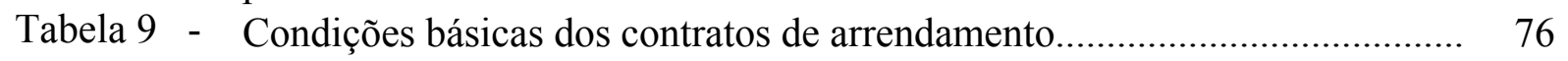

Tabela 10 - Valores máximos de financiamentos para o Programa Crédito Solidário..... 77

Tabela 11 - Resumo dos programas federais para o financiamento/arrendamento habitacional da população de baixa renda, em 2006................................... 79

Tabela 12 - Condições de financiamento dos Programas Carta de Crédito..................... 84

Tabela 13 - Estimativa da capacidade de financiamento e da necessidade de subsídios, por faixa de renda, para aquisição da HPR através dos programas Carta de Crédito.

Tabela 14 - Condições de arrendamento no PAR.

Tabela 15 - Estimativa da capacidade de arrendamento e necessidade de subsídios, por faixa de renda, para arrendamento da HPR através do PAR ................. 87

Tabela 16 - Condições de financiamento do PSH.......................................................... 88

Tabela 17 - Estimativa da capacidade de financiamento e necessidade de subsídios, por faixa de renda, para aquisição da HPR através do PSH......................... 89

Tabela 18 - Condições de financiamento do Programa Crédito Solidário....................... 89

Tabela 19 - Estimativa da capacidade de financiamento e necessidade de subsídios, por faixa de renda, para aquisição da HPR através do Programa Crédito Solidário.

Tabela 20 - Estimativa do preço da menor habitação popular......................................... 104 


\title{
LISTA DE ABREVIATURAS E SIGLAS
}

\author{
BNH Banco Nacional da Habitação \\ CCFGTS Conselho Curador do Fundo de Garantia do Tempo de Serviço \\ CEF Caixa Econômica Federal \\ COHAB Companhia de Habitação \\ DRAMA Demanda reprimida pela aquisição de moradias adequadas \\ FAR Fundo de Arrendamento Residencial \\ FAS Fundo de Atendimento à Saúde \\ FCVS Fundo de Compensação de Variações Salariais \\ FDS Fundo de Desenvolvimento Social \\ FGTS Fundo de Garantia do Tempo de Serviço \\ FINSOCIA Fundo de Investimento Social \\ FJP Fundação João Pinheiro \\ FNHIS Fundo Nacional de Habitação de Interesse Social \\ HPR Habitação popular referência \\ IBGE Instituto Brasileiro de Geografia e Estatística \\ INCC Índice Nacional de Custo da Construção \\ INPC Índice Nacional de Preço ao Consumidor \\ IPEA Instituto de Pesquisa Econômica Aplicada \\ OGU Orçamento Geral da União \\ PAR Programa de Arrendamento Residencial \\ PCR Plano de Comprometimento de Renda \\ PES Plano de Equivalência Salarial \\ PIB Produto Interno Bruto \\ PNAD Pesquisa Nacional por Amostra de Domicílios \\ PNH Plano Nacional de Habitação \\ PROTECH Programa de Difusão Tecnológica para a Construção de Habitação de \\ Baixo Custo \\ PSH Programa de Subsídio à Habitação \\ RMF Rendimento mensal familiar \\ SBPE Sistema Brasileiro de Poupança e Empréstimo \\ SFH Sistema Financeiro de Habitação \\ SFI Sistema de Financiamento Imobiliário \\ SM Salário mínimo \\ SNHIS Sistema Nacional de Habitação de Interesse Social
}




\section{INTRODUÇÃO}

\subsection{Justificativa}

De acordo com Hoek-Smit; Diamond (2003), a questão habitacional tem grande importância social e política na maioria das sociedades. Ela é um fator importante na criação de estabilidade, saúde pública, justiça social e estímulo ao crescimento econômico. Por estas razões, as sociedades intervêm nos mercados habitacionais mediante políticas e subsídios, com o objetivo de estimular a produção de moradias e de facilitar o acesso a estas por grupos diversos da população.

Segundo Jordan (2004), as estimativas são de que na América do Sul as necessidades habitacionais representam aproximadamente 38 milhões de unidades. Destas, $45 \%$ são quantitativas, ou seja, dependem da produção de novas unidades, e o restante é qualitativa, ou seja, relacionadas à necessidade de melhoramentos nas unidades. O Brasil é responsável pela maioria deste percentual que, segundo Vasconcelos; Cândido Júnior (1996) se aproxima de 20 milhões de pessoas que não dispõem de moradias adequadas, dos quais $70 \%$ se encontram em áreas urbanas. O World Bank (2002) estima que 22\% da população brasileira se encontra abaixo da linha de pobreza, sendo toda a sua renda, ou a maioria dela, destinada à alimentação, e que a maioria das novas famílias entrantes no mercado habitacional não tem renda suficiente para ter acesso a financiamentos habitacionais a juros de mercado.

A existência de necessidades habitacionais, como as descritas há pouco, tem duas causas principais, que podem existir isoladamente ou em conjunto. A primeira é a deficiência na produção de moradias, que pode não atender à demanda em qualidade, quantidade e/ou preços. A segunda é a dificuldade de acesso à moradia, seja por compra, reforma ou aluguel, pela insuficiência de renda, falta de crédito, falta de financiamentos adequados e/ou falta de subsídios direcionados à população de baixa renda. Sem acesso a habitações no setor formal, a população de baixa renda muitas vezes busca o setor informal, originando favelas, invasões, coabitações, assentamentos precários etc. 
De outro lado, os bens imobiliários, nos quais se enquadram as habitações, normalmente têm valores elevados e seus compradores uma capacidade limitada de pagar o preço, sobretudo nas faixas de menor poder aquisitivo. A sociedade, pois, necessita de financiamentos habitacionais para adequar sua capacidade de pagamento aos elevados valores dos imóveis.

Os financiamentos habitacionais, por sua vez, podem ser divididos em dois grupos principais: o financiamento da produção, que financia os produtores na construção de habitações, e o da demanda, que financia a população em geral na aquisição ou reforma de habitações, que podem ser novas ou mesmo usadas. Quanto a financiamentos habitacionais da demanda, a população pode ser dividida em dois grupos: os "Clientes Bancários", que possuem capacidade de pagar um financiamento imobiliário e podem ser financiados através de soluções de mercado, e os "Clientes Sociais", que necessitam de intervenções subsidiadas pelo Estado para aquisição e reforma de moradias, os quais serão o objeto desta pesquisa. Em cada caso, as fontes de recursos empregadas, bem como os instrumentos adotados por instituições financiadoras para habitação, têm características peculiares e devem adaptar-se às necessidades de cada tipo de cliente.

Os financiamentos habitacionais são, pois, fundamentais no acesso à habitação, principalmente para a população de baixa renda, seja para a aquisição de uma nova habitação ou para a reforma de uma que não possua condições adequadas. A existência desses financiamentos não indica a resolução do problema habitacional, pois, como é o caso do Brasil, onde nem sempre eles se adequam às necessidades da população de baixa renda, derivando, muitas vezes, para financiamento aos clientes bancários.

As políticas habitacionais no Brasil não têm obtido sucesso em alcançar seus objetivos, porque, segundo Vasconcelos; Cândido Júnior (1996), vários fatores influenciaram no seu insucesso, como inconsistência das regras do Sistema Financeiro da Habitação, incidência de compulsórios elevados sobre os depósitos de poupança, atuação do Poder Judiciário nas reclamações sobre os reajustes das prestações, exigibilidade de aplicações habitacionais a taxas tabeladas, altos índices inflacionários presentes na década de 1980, sucessivas quebras de contratos nos diversos choques econômicos, oscilações acentuadas nos fluxos de depósitos de poupança, altas taxas de juros do mercado e, principalmente, falta de segurança das instituições quanto ao quadro institucional e econômico para os anos seguintes. Uma das principais conseqüências do insucesso dessas políticas foi que os clientes sociais, embora 
inicialmente tenham sido o objetivo principal da maioria dessas políticas, acabaram por ser os menos favorecidos.

Em vista deste quadro, se faz necessário repensar os programas de financiamento habitacional no Brasil, sob novas perspectivas, principalmente à luz da capacidade de pagamento e das necessidades da população de baixa renda que, para ter acesso a moradias com mínimas condições de habitabilidade, precisa de financiamentos adequados. Como veremos na evolução deste trabalho, por não ter acesso às soluções de mercado, em sua maioria, a população de baixa renda fica à margem das soluções de financiamento habitacional.

Portanto, para a elaboração ou reformulação de uma política de financiamento habitacional, é necessário que, primeiramente, se analisem quais as reais necessidades e limitações da população à qual os financiamentos se destinam e que se confrontem estas necessidades e limitações com as condições ofertadas pelos financiamentos, determinando-se assim as necessidades não atendidas. Este trabalho visa a dar subsídios a instituições e pessoas que venham a participar da elaboração e estruturação de programas de financiamento habitacional, mediante a análise dos diversos fatores que compõem e influenciam estes programas, juntamente com uma caracterização de quem é a população de baixa renda brasileira e suas necessidades relativas a financiamentos habitacionais, de forma a encontrar caminhos que possam tornar mais eficientes estes programas e fazer com que eles possam realmente ajudar no acesso à habitação adequada pela população de baixa renda. 


\subsection{Objetivo}

O objetivo deste trabalho é fazer um diagnóstico dos programas de financiamento habitacional no Brasil quanto à adequação para atender a população de baixa renda na aquisição de moradias adequadas, e analisar, a partir daí, a suficiência na oferta de financiamentos para esta população, seja quanto à sua capacidade de pagamento, seja quanto ao volume de recursos ofertados.

Especificamente, este trabalho busca confrontar as necessidades habitacionais e a capacidade de pagamento da população de baixa renda com as condições e o volume de recursos ofertados pelos programas de financiamento habitacional voltados a esta população no Brasil, discutindo se a estrutura dos financiamentos, os subsídios e o volume de recursos ofertados atendem a demanda pela aquisição de moradias adequadas dessa população. 


\subsection{Metodologia}

Esta pesquisa primeiramente dedica-se à discussão dos principais conceitos relacionados à habitação. Inicia-se pela definição de habitação adequada, desde seu conceito básico até a conceituação de adequação habitacional adotada no Brasil. Posteriormente, descrevem-se os principais conceitos diretamente relacionados à habitação, como política habitacional, dinâmica do setor habitacional, o papel do Estado neste setor e os tipos e características dos subsídios habitacionais. Estas definições contribuem para uniformizar os conceitos que serão utilizados no desenvolver do trabalho.

$\mathrm{Na}$ segunda etapa, a pesquisa busca caracterizar o problema de aquisição de habitações adequadas pela população de baixa renda e determinar a demanda por financiamentos habitacionais desta população. Primeiramente, discute-se a grande e rápida migração da maioria população para áreas urbanas no Brasil, ocasionando grande concentração populacional urbana com dificuldades de acesso a habitações no setor formal. A partir daí, é feita a caracterização das necessidades habitacionais da população de baixa renda no Brasil, mediante a definição e quantificação das famílias de baixa renda que precisam de novas moradias (déficit habitacional), famílias que habitam em moradias que não oferecem condições mínimas aceitáveis de habitabilidade e precisam de melhorias (inadequação habitacional) e o surgimento vegetativo de famílias de baixa renda que necessitam de novas moradias (demanda demográfica). Em continuidade, será feita uma análise do orçamento familiar da população de baixa renda, destacando-se o percentual médio do orçamento destinado à habitação, juntamente com uma análise da forma segundo a qual essa população poderá pagar o preço de uma habitação adequada no setor formal.

A terceira etapa do trabalho trata da descrição dos programas de financiamento habitacional voltados à população de baixa renda no Brasil, destacando-se suas principais características que interferem no acesso da população de baixa renda à habitação. Inicia-se com uma análise histórica dos principais financiamentos habitacionais implementados no Brasil e seus resultados. Posteriormente, são descritos os principais programas de financiamento habitacional atualmente ofertados no Brasil para a população de baixa renda, onde será feita uma análise de cada um deles, enfocando-se suas estruturas, objetivos, prazos, fontes de 
recursos e o volume total de recursos ofertados para o financiamento habitacional da população de baixa renda. Ao final, ficará reconhecida a oferta de recursos para o segmento.

Na última etapa, confrontam-se a capacidade de pagamento da população de baixa renda e as condições ofertadas pelos programas de financiamento e subsídios, para aquisição de uma habitação adequada, mostrando-se onde há desajuste e o que o provoca, com a determinação das principais características dos financiamentos que interferem na acessibilidade da população de baixa renda à habitação adequada. Em continuidade, analisar-se-á a necessidade de ampliação dos programas de financiamento habitacional, com base na projeção do volume de recursos necessários para atender a demanda pela aquisição de moradias adequadas. Serão feitas, então, sugestões para uma melhor adequação dos programas de financiamento habitacional e da política de subsídios voltados à população de baixa renda no Brasil à luz das suas necessidades e limitações, fechando-se com as conclusões.

Este trabalho terá como principal fonte de dados a bibliografia constante de publicações nacionais e internacionais, como livros, artigos, revistas especializadas e seminários. 


\section{HABITAÇÃO}

O objetivo deste Capítulo é definir os principais conceitos básicos que envolvem habitação e suas variáveis, desde a definição básica de habitação adequada até a dinâmica de como funciona o setor habitacional.

\subsection{Habitação Adequada}

Em termos gerais, habitação significa abrigo. Com o objetivo de se proteger contra intempéries e ameaças externas, o homem vem, ao longo do tempo, aprimorando os materiais, as formas e as funções das habitações, fazendo este conceito ganhar amplitude e se tornar mais importante do que somente ter a função de abrigar. Com o advento das cidades, as habitações ganham importância econômica ao se tornarem o local onde a força de trabalho desempenha várias atividades primárias, necessárias à sua sobrevivência, como alimentação, descanso, entretenimento, atividades fisiológicas, convívio social etc.

O direito à habitação se tornou, então, uma necessidade básica, como alimentação, saúde e vestimenta. Foi incluído na Declaração Universal dos Direitos Humanos, em 1948, cujo texto, em seu artigo 25 , declara que todos têm o direito a um padrão de vida adequado à saúde e bem-estar de sua família, incluindo alimentação, vestimenta, moradia, cuidados médicos e os serviços sociais necessários, bem como o direito à segurança em caso de desemprego, enfermidade, invalidez, viuvez, velhice ou circunstâncias outras, além de seu controle. A Declaração de Vancouver, oriunda da $1^{\text {a. }}$ Conferência das Nações Unidas sobre Assentamentos Humanos (HABITAT I), que aconteceu em 1976, apresenta um consenso internacional relativo às políticas acerca dos assentamentos humanos, reafirmando a habitação adequada e os serviços como um direito humano básico e apontando a responsabilidade dos governos por ações visando a assegurar este direito. Duas décadas depois, foi promovida a $2^{\text {a. }}$ Conferência das Nações Unidas sobre Assentamentos Humanos (HABITAT II), que reafirmou como princípios e objetivos essenciais a habitação adequada para todos, como um direito que deve ser assegurado (LORENZETTI, 2001). 
Embora exista o reconhecimento internacional de que a habitação adequada é crucial para a saúde e bem-estar dos indivíduos, existem ainda algumas dificuldades no atendimento deste direito, começando pela definição do que é habitação adequada. A adequabilidade de uma habitação não diz respeito somente às suas características intrínsecas, mas ao que ela representa para a família que a habita, levando-se em conta fatores subjetivos de cada país, como diferenças culturais, diversidade de necessidades e preferências. Em outras palavras, o que é adequado para uma sociedade pode não o ser para outra, com cultura diferente.

Segundo Abiko (1995), para que uma habitação cumpra suas funções, é necessário que, além de um espaço confortável, seguro e salubre, esteja integrada ao entorno, ao ambiente que a cerca, não se restringindo somente à unidade habitacional. Para o caso das populações urbanas no Brasil, este conceito envolve

- serviços urbanos, isto é, as atividades desenvolvidas no âmbito urbano que atendam às necessidades coletivas: abastecimento de água, coleta de esgotos, distribuição de energia elétrica, transporte coletivo, etc;

- infra-estrutura urbana incluindo as redes fisicas de distribuição de água e coleta de esgotos, as redes de drenagem, as redes de distribuição de energia elétrica, comunicações, sistema viário, etc.;

- $\quad$ equipamentos sociais incluindo os edificios e instalações destinadas às atividades relacionadas com educação, saúde, lazer, etc.(ABIKO, 1995, p.3)

A definição sobre habitação adequada dada pela Conferência das Nações Unidas sobre Assentamentos Humanos, HABITAT ${ }^{1}$ (1989 apud ABIKO, 1995, p.4), é que habitação adequada é aquela que se constitui a partir dos seguintes critérios:

- estrutura fisica: uma habitação adequada deve oferecer proteção contra os elementos, não deve ser úmida ou inabitável e deve ser culturalmente aceitável;

- situação do terreno: uma habitação deve garantir a segurança física de seus habitantes, deve ser um lugar seguro para viver, criar filhos e promover saúde;

- infra-estrutura/serviços: uma habitação adequada deve contar com certos serviços essenciais voltados para a saúde, o conforto e a

\footnotetext{
${ }^{1}$ HABITAT, United Nations Centre for human Settlements. Global strategy for shelter to the year 2000. Nairobi, 1989.
} 
nutrição, estes incluem um abastecimento de água seguro e em quantidade suficiente, serviços de eliminação de dejetos domésticos e humanos, serviços de lavanderia, cocção e armazenamento de alimentos, e calefação, quando necessário, devem incluir também certos serviços públicos como serviços de emergência e auxílio (ex,.: bombeiros e ambulâncias).

- acessibilidade: uma habitação adequada deve ser acessivel a um custo tal que não dificulte ou impossibilite o enfrentamento de outras necessidades básicas a pessoas de todos os setores da sociedade;

- localização: uma habitação adequada deve estar em um local que permita o acesso ao emprego, serviços de saúde, escolas e outros serviços sociais, este critério é válido tanto nas cidades como nas zonas rurais, porque o custo de transporte aos locais de trabalho representa um gasto considerável nos orçamentos das familias pobres;

- segurança legal: uma habitação adequada deve possuir segurança de posse; este critério é aplicável aos direitos de propriedade, à intimidade etc. no caso das pessoas ocuparem a sua própria casa, e aos direitos de posse para aquelas que alugam espaços para viver, por exemplo os direitos legais dos inquilinos e dos proprietários; a segurança legal, ou garantia de posse deve também ser aplicável aos que ocupam as habitações em forma precária, evitando o despejo forçado por parte dos proprietários; este direito deve incluir o direito à proteção das posses contidas no interior das habitações, visando impedir a sua expropriação por parte de proprietários, de governos e de terceiros.

Pode-se ver pelo exposto, que as características individuais da habitação e o contexto urbano que a cercam são interdependentes e determinantes para o conceito de adequação habitacional. Abiko (1995, p.5) constata que

[...] esta conceituação parece lógica e óbvia porém é extremamente dificil transpor esta visão para uma implementação operacional. Uma das razões para esta dificuldade é que a responsabilidade técnica e administrativa dos vários sub-sistemas urbanos estão ligados a diferentes esferas de governo: municipal, estadual e federal [...].

\subsection{Política Habitacional}

A definição de modelo de política habitacional pode ser entendida, segundo Arretche (1990, p. 21), "como a identificação das características estruturais de distintas modalidades de interferência estatal no mercado habitacional, isto é, nos processos de produção, distribuição e consumo de unidades residenciais". 
A política habitacional, embora muito importante, não é uma atividade essencial ${ }^{2}$ do Estado ${ }^{3}$, enquadrando-se como uma atividade complementar. Assim, o Estado pode ter diferentes ações na interferência com o mercado habitacional, dependendo de como os governantes vêem a importância da habitação em comparação com as atividades essenciais e com as outras atividades complementares, de como o mercado habitacional funciona sem a interferência do Estado e dos recursos disponíveis neste que possam ser destinados à habitação.

Existem diversos instrumentos que o Estado pode utilizar para executar suas estratégias e políticas habitacionais. Segundo Grimes Jr. (1976), os mais importantes são zoneamento, controle do código de construção, gerenciamento da propriedade imobiliária, aumento ou diminuição de impostos e taxas, oferta de subsídios, ajuda ao desenvolvimento de instituições financeiras para o financiamento habitacional e ajuda ao desenvolvimento das indústrias de construção e de materiais de construção.

\subsection{O setor habitacional}

O setor habitacional é importante na maioria das economias. Investimentos em habitação compreendem aproximadamente entre $2 \%$ e $8 \%$ do Produto Interno Bruto (PIB) da maioria dos países em desenvolvimento. Combinando-se investimentos com serviços neste setor, este percentual aumenta para aproximadamente entre 7\% e 18\% do PIB. Este setor deveria então ser tratado como uma parte fundamental da economia, mas muitos governos ainda o tratam como somente uma questão de bem-estar da população (WORLD BANK, 1993).

No setor habitacional, como na maioria dos outros, seus resultados são determinados basicamente pela relação entre a oferta e a demanda que, por sua vez, recebem influências de outros fatores, como será visto a seguir. O modelo simplificado que segue representa estas relações:

\footnotetext{
2 "Fins essenciais são aqueles que o Estado tem de realizá-los sob pena de não ser Estado, como a defesa externa, a manutenção da ordem interna, a atividade financeira, a função de dizer o Direito e essas funções não indelegáveis em razão da indisponibilidade do interesse público, isto é, têm de ser executadas pelo Poder Público. A par das funções privativamente estatais há funções de natureza complementar que o Estado pode exercer por si, por terceiros ou deixar de exercer, com certas atividades de ordem econômica, de aperfeiçoamento, etc. , que não afetam a existência do Estado." (Nogueira, 1989 apud Gomes, 1993, p.5).

NOGUEIRA, Ruy Barbosa. Curso de direito tributário. 9 ed. São Paulo, Editora Saraiva, 1989.

${ }^{3}$ Por Estado entende-se os Governos Municipal, Estadual, DF e Federal.
} 


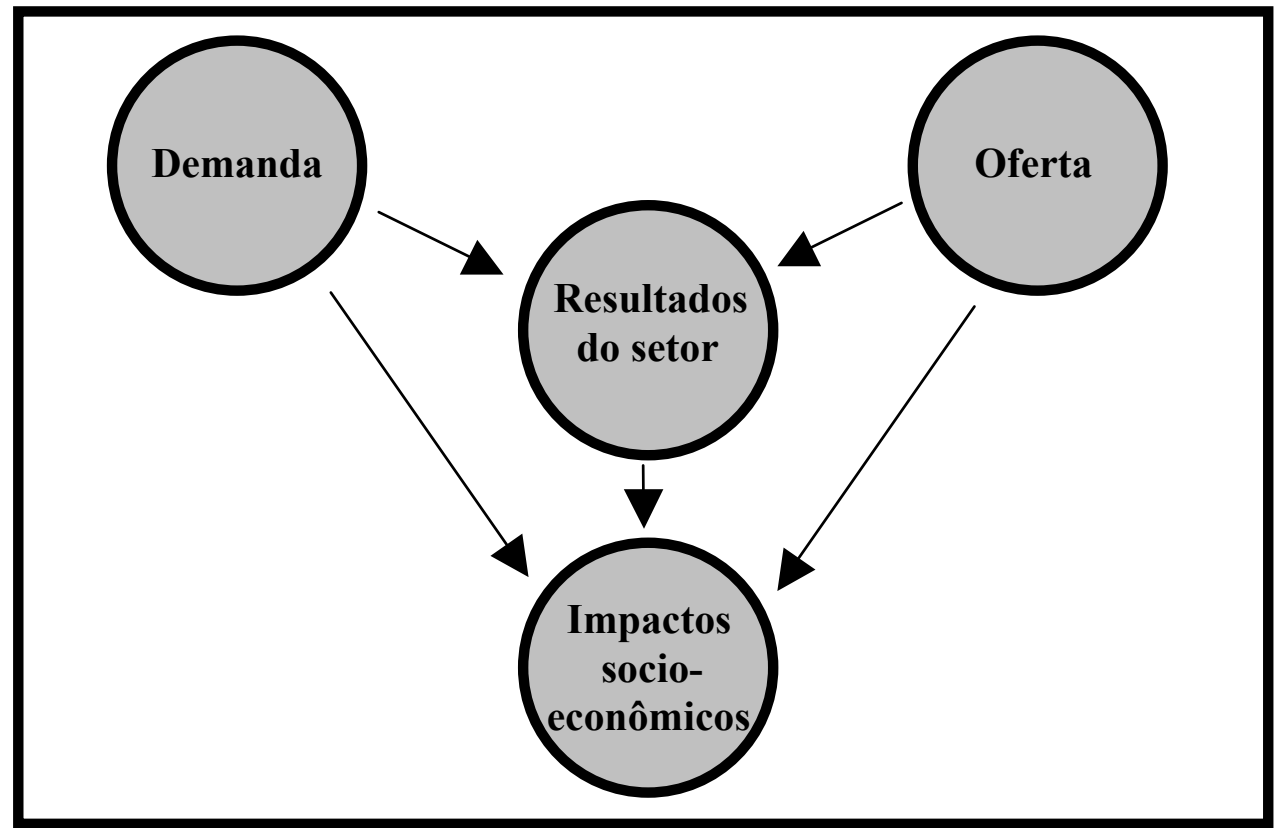

Fonte: World Bank (1993).

Os resultados do setor, que incluem os preços das habitações, o tamanho e a condição do estoque de habitações, as necessidades habitacionais da população, o volume de recursos para investimento, dentre outros, afetam condições socioeconômicas mais amplas, como a qualidade de vida da população, as taxas de desemprego, a saúde pública, o crescimento econômico, a distribuição de renda, dentre outros.

O World Bank (1993, p.21) expressa ainda que, os parâmetros principais necessários para entender-se a dinâmica do setor habitacional são:

(i) a elasticidade da demanda com relação à renda e ao preço da habitação (que mede a sensibilidade com relação a mudanças no preço e na renda);

(ii) a propensão da população de gastar em habitação (que mede a parcela do orçamento familiar destinada à habitação)

(iii) a elasticidade da oferta de habitações com relação ao preço (que mede a sensibilidade da oferta com relação a variações nos preços da habitação);

(iv) os custos médios da oferta de habitações. Estes parâmetros influenciam a forma das curvas de demanda e oferta. 


\subsubsection{Demanda}

Além da oferta, a demanda por habitações é objeto de importantes influências de outros fatores, dos quais os principais são:

- $\quad$ a renda - é o principal fator influenciador da demanda. Segundo Grimes Jr. (1976), o problema habitacional nos países em desenvolvimento tem como causa principal a inadequação da renda de um grande número de famílias para pagar o preço da habitação. São necessários recursos para a aquisição, reforma ou aluguel de habitações, ou mesmo para o pagamento de financiamentos que possibilitem isso;

- a segurança do direito à propriedade - a garantia do direito à propriedade dá segurança aos investimentos em habitação. A segurança do direito à propriedade deve ser de caráter exclusivo e absoluto, ou seja, a propriedade não pode pertencer a dois ou mais proprietários e o proprietário deve ter o direito de se opor à ação de terceiros exercida sobre aquilo que lhe pertence; o direito à propriedade é importante também para que a propriedade possa servir como garantia ${ }^{4}$ para financiamentos habitacionais. Buckley (1996) exprime que, quando o direito à propriedade é ambíguo, ou os procedimentos de retomada de propriedade em caso de inadimplência são incertos, o que a princípio caracterizaria o financiamento imobiliário como um financiamento de baixo risco para as entidades financiadoras, torna-se uma prática de grande risco, desencentivando e/ou tornando mais caros os financiamentos;

- o financiamento da demanda - como o valor de uma unidade habitacional normalmente é muitas vezes superior à renda anual da população em geral, o financiamento para compra de habitações se torna essencial. Este princípio também é válido para reformas de habitações, que muitas vezes também envolvem valores elevados, e para o aluguel de habitações, pois normalmente aqueles que compram habitações para alugar também usam financiamentos habitacionais para fazê-lo, influenciando assim a demanda. Cabe ressaltar que a dimensão da compra de habitações visando ao aluguel no Brasil, consideradas as leis do inquilinato, é pouco representativa; 
- $\quad$ os impostos e taxas - incidem sobre as várias etapas da compra, reforma ou aluguel de habitações, como impostos sobre propriedade, transferência, materiais de construção, serviços etc. aumentam os custos envolvidos nas transações imobiliárias; e

- os subsídios - funcionam de forma inversa às taxas e impostos, facilitando o acesso a habitações para classes sociais que de outra forma não teriam acesso.

A demanda, portanto, não se limita apenas à existência ou não de necessidades habitacionais, mas também à capacidade de pagamento das famílias e quanto de sua renda pode ser destinada à habitação.

\subsubsection{Oferta}

Segundo o World Bank (1993), países possuem diferentes eficiências nos seus sistemas de produção de habitações, principalmente em relação à quantidade e diversidade de habitações produzidas, custos de produção e preços nos quais estas habitações são vendidas.

Além da demanda, são os seguintes os principais fatores que influenciam a oferta de habitações:

- $\quad$ provisão de infra-estrutura - se a provisão de infra-estrutura não responde à demanda por habitações, os preços dos terrenos com infra-estrutura tendem a aumentar, com o conseqüente aumento nos preços finais das habitações;

- $\quad$ estrutura legal e de regulamentação - áreas urbanas têm diferentes regulamentações, influenciando o custo e o preço dos terrenos e do sistema de construção de habitações. Normalmente estas regulamentações visam a melhorar a qualidade do meio ambiente e a eficiência do desenvolvimento urbano. Os principais exemplos são - códigos de construção, que determinam as características arquitetônicas e construtivas permitidas, juntamente com exigências mínimas relativas às instalações hidro-sanitárias e elétricas

\footnotetext{
${ }^{4}$ A habitação popular, como garantia de financiamentos habitacionais, está sujeita, também, ao risco de desvalorização devido a fatores relativos ao bairro que a cerca, como deterioração urbana, aumento da criminalidade etc.
} 
das habitações; padrões de infra-estrutura especificam níveis de serviços mínimos admitidos, tipos de materiais, padrões para construção de rodovias, redes de drenagem, esgoto, água e rede elétrica; uso da terra e zoneamento controlam a subdivisão das propriedades, objetivo de utilização, densidades residenciais, determinação de áreas públicas etc. A regulamentação, embora traga benefícios para a sociedade, pode trazer várias conseqüências que ocasionam consideráveis aumentos dos custos de produção de habitações. Regulamentações que têm padrões com exigências muito acima da realidade do país em que se aplicam, podem tornar impossível a construção legal de habitações para as classes de baixa renda. Podem também criar barreiras burocráticas que dificultem a velocidade de resposta da oferta de habitações em relação ao crescimento da demanda. Segundo o World Bank (1993), a estrutura legal e de regulamentação do setor é um dos fatores mais importantes que influenciam a eficiência e a velocidade de resposta do setor produtivo de habitação ante a demanda, existindo parâmetros que apontam para variações de até 30\% na velocidade de resposta do setor produtivo diante de variações na demanda em razão de sistemas legais e de regulamentação mais simples e eficientes em alguns países;

o financiamento da produção - a existência de linhas de financiamento da produção de habitações possibilita a diminuição da quantidade de recursos próprios que produtores teriam que ter imobilizado, por longos prazos, em cada empreendimento, no caso da não-existência deste tipo de financiamento, possibilitando um aumento do poder multiplicador dos recursos do produtor;

os custos de construção - variam consideravelmente entre países, em decorrência dos diferentes custos dos materiais de construção e da mão-de-obra, juntamente com as diferentes técnicas construtivas utilizadas. Estudos do World Bank (1993) mostram que, tanto em países desenvolvidos como em desenvolvimento, a produção de habitações pelo Estado mostra-se na maioria das vezes ineficiente em comparação com a iniciativa privada, ocasionando maiores custos de construção e pior qualidade das construções. A existência de monopólios públicos ou privados no setor da construção civil, tanto nos serviços de construção como na fabricação de materiais, diminui a eficiência do mercado, ocasionando aumento de custos do setor como um todo. 


\section{$2.4 \quad$ O papel do Estado}

As políticas habitacionais dos Estados devem ser elaboradas e implementadas de forma que abordem as causas dos problemas habitacionais e não os seus sintomas, utilizando os conhecimentos sobre os mercados habitacionais para fazerem com que estes funcionem de forma independente, com a menor intervenção estatal possível.

Em vez de criar grandes políticas de subsídios, que têm um preço alto e muitas vezes não alcançam os objetivos esperados, ou partir para a produção de milhares de residências populares, que muitas vezes são feitas com baixa eficiência e que não atendem as expectativas de preço, localização e qualidade dos consumidores ${ }^{5}$, os Estados devem partir para ajudar na ordenação e viabilização dos principais fatores que fazem com que o mercado habitacional funcione de forma independente e atenda grande parte das necessidades habitacionais da população. A intervenção estatal deve visar predominantemente às parcelas que o mercado não atende, as quais geralmente se encontram nas populações de renda mais baixa.

O World Bank (1993), em seu estudo intitulado Housing :Enabling Markets to Work, coloca que o Estado deve ajudar na melhoria das imperfeições do mercado, garantindo que o setor habitacional funcione melhor. Deve eliminar e/ou mitigar as causas de falhas no mercado, mas, ao mesmo tempo, evitar intervenções que o distorçam, por meio do tratamento das causas e não dos sintomas. Existem basicamente sete causas principais de imperfeições no mercado nas quais o Estado pode intervir, sendo três para estimular a demanda, três para estimular a oferta e uma para possibilitar a criação de uma estrutura que possa gerenciar o setor habitacional, garantindo acesso à habitação para a população de baixa renda. Estas são as seguintes (WORLD BANK, 1993):

\footnotetext{
${ }^{5}$ Como exemplo da ineficiência que os Estados podem apresentar quando assumem a função de produtores em massa de habitações, pode-se citar o ocorrido no Brasil nos anos de 1990 e 1991, quando houve uma retomada das operações com recursos do FGTS após a extinção do BNH. Neste período, foram contratadas a produção de 526 mil unidades habitacionais, que comprometeram o orçamento do FGTS nos anos seguintes, impedindo a realização de novas operações. De acordo com Gonçalves (1997, p.28 apud Santos, 1999), "boa parte das 526 mil unidades produzidas visaram a atender objetivos políticos e muitas delas apresentaram problemas de comercialização, sendo que no final de 1996 mais de 50 mil delas não haviam sido comercializadas e um número expressivo delas não tinha sua construção concluída. Boa parte delas, inclusive, só terá sua comercialização viabilizada por valor bem inferior ao custo incorrido em sua produção, demonstrando que sua contratação não observou os critérios técnicos requeridos."

GOLÇALVES, J. P. Acesso ao financiamento para a moradia pelos extratos de média e baixa renda: a experiência recente. CEPAL, 1997. (Serie Financiamento del Desarrollo).
} 
- desenvolver o sistema de direito à propriedade - melhorar o sistema de transferência e registro de propriedades, garantindo o direito à propriedade em sua plenitude e criando sistemas ágeis, eficientes e seguros de registro;

- desenvolver o sistema de financiamento habitacional - as políticas financeiras devem permitir que as instituições financeiras financiem habitações a juros de mercado. A competição entre instituições deve ser encorajada para aumentar a eficiência do setor. Os instrumentos utilizados para o financiamento devem permitir o equilíbrio de interesses entre as partes, incluindo a indexação do financiamento. O imóvel usado como garantia deve ter a segurança do direito à propriedade e a velocidade na recuperação do imóvel em caso de inadimplência do financiamento;

racionalizar subsídios - estes devem ser vistos pelo Estado como uma alternativa transitória e/ou como última solução. Primeiro, deve-se tentar outras formas de facilitar o acesso a habitações, ajudando-se o mercado a funcionar por si próprio. Em caso de real necessidade de subsídios, estes devem ser bem direcionados, transparentes, mensuráveis e devem trazer as menores distorções possíveis ao mercado;

- desenvolver a regulamentação do uso da terra e da construção - as regulamentações devem promover o equilíbrio entre os custos e benefícios que influenciam os mercados de habitação, principalmente quanto ao uso da terra e da construção. As regulamentações devem, então, ser revisadas à luz dos seus impactos na demanda, na oferta e nos preços das habitações;

- desenvolver a organização da indústria da construção - o Estado deve buscar aumentar a competição nesta indústria pela eliminação de barreiras para entrada de novas empresas, eliminação de monopólios e remoção de regulamentações que dificultem o desenvolvimento do mercado;

- estruturar o Estado para gerenciar o setor habitacional - podem ser desenvolvidas ferramentas para que o Estado possa coletar, analisar, interpretar e publicar informações sobre o desempenho do setor habitacional, principalmente o seu desempenho relativamente à população de baixa renda; considerar o setor habitacional no planejamento macroeconômico do País; promover fóruns entre o Estado e a iniciativa privada para discussão de planos para o setor; e se manter atento às populações de baixa renda, de modo a garantir que estas também tenham acesso à habitação. 


\subsection{Subsídios para o acesso à habitação}

$\mathrm{Na}$ maioria dos países em desenvolvimento, enquadrando-se aqui o Brasil, os mercados formais de habitação falham em atender à população de baixa renda. Muitas vezes, a maioria da população não é capaz de pagar o menor preço existente pela habitação mais simples no mercado formal. Ferguson (2004) constata que 65\% da população da América Latina não consegue adquirir a mais barata das habitações. A saída para estas famílias, que não têm acesso à habitação, é dividir habitações com parentes e/ou construir ou alugar habitações subnormais ${ }^{6}$.

Os subsídios se tornam, então, ferramentas fundamentais para possibilitar o acesso à habitação, seja pela compra ou reforma, para a população de baixa renda ${ }^{7}$ e às vezes também a de média renda. A definição de subsídios muitas vezes é confundida com dar ou receber alguma coisa gratuitamente, sendo esta uma compreensão errônea. Hoek-Smit; Diamond (2003) definem subsídio como "[...] um incentivo dado pelo governo para possibilitar e persuadir uma certa classe de produtores ou consumidores a fazer alguma coisa que, de outra forma, eles não fariam, pela diminuição do custo de oportunidade ${ }^{8}$ ou pelo aumento dos benefícios potenciais de fazê-lo".

Hoek-Smit; Diamond (2003) expressam, ainda, que os principais motivos que levam um governo a fazer uma intervenção no setor habitacional mediante subsídios são:

- $\quad$ melhoria da saúde pública - na maioria dos países, o motivo principal para o subsídio de habitações é o de se assegurar que boas condições de vida, incluindo-se aqui também o

\footnotetext{
${ }^{6}$ Habitação subnormal é definida "como aquela que não oferece as condições mínimas de segurança, durabilidade, tamanho, salubridade e não permite a seus moradores o atendimento das atividades como membro de grupos primários; estas condições referem-se tanto aos aspectos da construção (dimensionamento, número e disposição dos cômodos, material, estrutura, etc.) quanto à carência e localização de sanitários, ausência de água encanada, de ligação às redes de esgoto e de energia elétrica". (VÉRAS, 1987 APUD ABIKO, 1995, p.12).

VÉRAS, M.P.B. Os impasses da crise habitacional em São Paulo ou os nômades urbanos no limiar do século XXI. Revista São Paulo em perspectiva, 1(1):40-58, abr.jun. 1987.

${ }^{7}$ Embora não seja abordado neste trabalho, é importante apontar que, mesmo conseguindo o acesso à habitação através de subsídios, a população de mais baixa renda, muitas vezes, não consegue arcar com as despesas decorrentes da propriedade de uma habitação no setor formal, como impostos e taxas, água, esgoto, energia etc., se vendo obrigada a migrar para habitações subnormais em favelas, invasões etc., onde, em decorrência da situação informal da habitação e da inexistência de instalações de água e/ou energia, ou mesmo da ligação ilegal destas, tais despesas muitas vezes não são pagas.
} 
fornecimento de água e esgoto que devem fazer parte de uma habitação adequada, evitariam o surgimento de epidemias;

- melhoria da igualdade e justiça social - o segundo motivo principal é o de melhorar a renda e a distribuição de riquezas na sociedade. Entende-se que as condições de habitação afetam as oportunidades das pessoas em melhorar suas chances de sucesso na vida. Por exemplo, ter energia elétrica para estudar em casa, ter acesso a boas escolas, ter boas condições de transporte etc.;

- $\quad$ suplantar ineficiências de mercado e de regulamentação - diminuir problemas ligados ao acesso a financiamentos habitacionais e/ou à baixa qualidade de habitações e/ou a um volume insuficiente de novas construções, particularmente no setor de baixa renda;

- estimular o crescimento econômico - o aquecimento do setor habitacional cria empregos não somente no setor da construção civil mas também nas indústrias que fornecem materiais para construção. Existe, então, um efeito multiplicador de empregos quando se constroem novas habitações, que estimulam a economia mais do que outras formas de gastos governamentais, fazendo esta solução ser bastante usada por governos após recessões e depressões, dando um impulso à economia.

Hoek-Smit; Diamond (2003) argumentam ainda que a estruturação de uma política de subsídios para enfrentar tais situações é complexa, devendo fugir de objetivos amplos, como "prover cada família com uma casa decente e um ambiente saudável”. Portanto, antes de se implementar uma política de subsídios, é necessário que seus elaboradores conheçam, em profundidade, as causas das dificuldades encontradas pela oferta e pela demanda por habitações. O primeiro passo é a determinação clara dos objetivos desta política, determinando se a solução passa pela criação de subsídios ou por mudanças na regulamentação do setor, ou mesmo por ambas. É importante que, no mínimo, sejam feitas as seguintes análises, verificando-se se:

- a deficiência na oferta de habitações no setor formal decorre de falhas da política em vigor no ambiente da regulamentação do setor que estariam em desacordo com o que as

\footnotetext{
${ }^{8}$ Custo de oportunidade : custo de algo em termos de uma oportunidade renunciada.
} 
famílias podem pagar ou com o que minimamente se aceita do ponto de vista de habitação adequada; ou as regulamentações estão alinhadas, mas parte da população é que geralmente não tem o mínimo suficiente de rendimentos para aquisição ou aluguel dessas habitações;

- $\quad$ a dificuldade de acesso a financiamentos habitacionais é a razão principal porque parte da população não consegue adquirir ou reformar habitações; ou estes problemas decorrem de sistemas de monopólios públicos ou privados ou outras formas de falhas no sistema; ou das condições macroeconômicas vigentes e não do sistema de financiamento em si; ou os fornecedores de crédito estão relutantes em entrar no mercado da população de baixa renda, porque não conseguem mensurar o custo e mitigar o risco de fornecer crédito para este mercado; ou existe incerteza sobre os retornos futuros dos financiamentos, pois os riscos de inadimplência são muito altos;

- $\quad$ existem problemas no acesso às propriedades servidas de infra-estrutura em razão de monopólios públicos ou privados; ou porque o governo é incapaz de oferecer infraestrutura em tempo hábil.

Uma vez que os elaboradores de políticas habitacionais entendam as causas das deficiências tanto na produção como no acesso a habitações, podem decidir se a melhor solução para cada situação seria a utilização de subsídios a produtores e/ou consumidores e/ou mudanças na regulamentação do setor.

A utilização de subsídios deve ser precedida e/ou ser utilizada em conjunto com outras ações governamentais que a complementem, como desenvolver e reformar instituições e políticas, visando a facilitar o papel de entidades financiadoras e produtoras de habitações, sejam estas públicas ou privadas, na expansão e melhoria da oferta de habitações e de programas de financiamento voltados à população de baixa e média renda, e melhorar o sistema de regulamentação do setor em diferentes esferas (aquisição de terra, produção, consumo, financiamento, infra-estrutura etc.), buscando permitir que mais famílias tenham acesso à habitação adequada. Sem essas medidas complementares, que melhoram a eficiência do mercado, e que muitas vezes substituem a necessidade de subsídios, a implementação de uma política de subsídios pode não gerar os resultados esperados. 
Segundo Hoek-Smit; Diamond (2003) as principais formas de subsídios habitacionais são:

- subsídio dos juros de financiamentos habitacionais diretamente às instituições financiadoras - o Estado intervém diretamente, pagando parte dos juros junto às instituições financiadoras que praticam os juros de mercado;

- $\quad$ subsídio dos juros de financiamentos habitacionais usando fundos especiais - utilização pelo Estado, de fundos especiais compostos de recursos provenientes de cobranças compulsórias sobre a população, como seguridade social, taxas sobre salários, contribuições para aposentadoria etc. que podem financiar a demanda por habitações por juros mais baixos que os de mercado;

- $\quad$ subsídio dos juros de financiamentos habitacionais pela dedução de impostos - do valor dos impostos a serem pagos é deduzido o valor de juros pago relativamente aos financiamentos habitacionais;

- $\quad$ o Estado dá suporte à criação de poupanças de longo prazo voltadas à habitação - os poupadores recebem um bônus baseado nas quantias poupadas em cada ano, mas estas poupanças só poderão ser retiradas após um mínimo preestabelecido de tempo, garantindo assim que estes valores poderão financiar outros poupadores. Estes fundos são gerenciados por instituições especializadas e investem em financiamentos habitacionais com baixas taxas de juros;

- $\quad$ seguros e garantias patrocinadas pelo Estado para o risco do mercado primário - o Estado assume totalmente ou em parte o risco de crédito associado a uma parcela específica dos financiamentos habitacionais, conseqüentemente diminuindo o risco das entidades financiadoras e os juros cobrados por elas para estes financiamentos; e

- $\quad$ subsídios mediante aportes diretos de recursos aos consumidores - este é o modo mais simples e direto de subsídio, em que o Estado aporta dinheiro diretamente como parte do financiamento por meio da quitação de parcelas ou da entrada do imóvel, normalmente restrito à população de baixa renda e a compra da primeira habitação. 
Existem diversas formas de subsidiar habitações, além das descritas há pouco, tanto para a produção como para a demanda por habitações, ou mesmo a utilização de várias dessas soluções em conjunto, dependendo de cada caso. Existem, porém, diferenças entre se subsidiar a produção ou a demanda por habitações, como segue:

- o subsídio da demanda foca no aumento da possibilidade de famílias consumirem habitações, de melhorarem as habitações em que moram ou mesmo de consumirem um tipo particular de habitação, podendo ser por compra, reforma ou aluguel. Hoek-Smit; Diamond (2003) acentuam que o subsídio da demanda por habitações é considerado mais eficiente que o subsídio da produção, pois dá aos beneficiários a possibilidade de escolherem se querem comprar, reformar ou alugar habitações, como também a localização mais adequada às suas necessidades e o tipo de habitação que mais agrada;

- $\quad$ o subsídio da produção foca principalmente na diminuição do custo de oportunidade e/ou dos riscos envolvidos na produção de habitações. Ele pode ser ofertado mediante financiamentos diretos do Estado, provisão de infra-estrutura, benefícios fiscais, seguros para riscos de crédito e inadimplência etc. Hoek-Smit; Diamond (2003) argumentam que, em geral, a desvantagem do subsídio da produção é que, quando usado inapropriadamente, distorce o mercado, principalmente quando o Estado assume funções que poderiam ser feitas mais eficientemente pelo setor privado, impedindo muitas vezes a expansão e evolução do setor privado na produção de habitações.

$\mathrm{Na}$ decisão do uso ou não de subsídios, ou no caso da escolha do tipo ou dos tipos de subsídios a serem implementados, é importante que os elaboradores de políticas habitacionais avaliem os objetivos dessas políticas de intervenção governamental no mercado habitacional à luz das seguintes análises, que segundo Hoek-Smit; Diamond (2003), devem ser:

- quanto à eficiência - analisar o valor dos custos efetivos, diretos e indiretos, e se eles podem ser diminuídos sem impacto nos resultados pretendidos; relação entre os benefícios sociais e econômicos gerados e os custos efetivos dos subsídios; se os benefícios gerados substituiriam os investimentos que os beneficiários destes já fariam de qualquer forma, mesmo sem a existência dos subsídios; se os benefícios estimados 
dos subsídios serão valorizados pelos beneficiários de forma igual ou maior do que os custos efetivos incorridos pelo Estado (custo de oportunidade);

- $\quad$ quanto à eqüidade - analisar a eqüidade horizontal, beneficiários dentro da mesma faixa de renda, buscando que os subsídios sejam os menores possíveis por beneficiário, de forma a alcançar o maior número possível de beneficiários; e a eqüidade vertical, beneficiários de faixas de renda diferentes, evitando subsídios tão grandes que possibilitariam que beneficiários adquirissem habitações com atributos da qualidade ${ }^{9}$ acima daqueles dos estratos de renda mais altos, mas que não têm acesso aos mesmos subsídios;

- quanto à transparência - os custos dos subsídios devem poder ser medidos e apresentados de forma explícita e clara, preferencialmente mostrados no orçamento do Estado; e o processo de seleção dos beneficiários deve ser claro e transparente para todos;

- quanto às distorções do mercado - os subsídios normalmente distorcem o mercado de alguma forma, mas o Estado deve cuidar para que estas distorções sejam as menores possíveis, buscando sempre, e em primeiro lugar, possibilitar que os mercados funcionem de forma independente;

- quanto à mobilidade dos beneficiários - as políticas de subsídios devem cuidar para que os beneficiários possam escolher os locais onde queiram comprar, reformar ou alugar suas habitações, dependendo de suas necessidades, como trabalho, proximidade dos familiares, transporte etc. evitando programas que obriguem os beneficiários a escolherem locais pré-fixados, como, por exemplo, grandes conjuntos habitacionais produzidos pelo Estado; e

- quanto à facilidade administrativa - as políticas de subsídios devem procurar diminuir a carga de controle e acompanhamento necessários ao gerenciamento dos programas de subsídios, diminuindo-se os custos administrativos, que podem ser complementados pelo uso de parceiros privados para sua execução.

\footnotetext{
${ }^{9}$ Os atributos da qualidade de um empreendimento habitacional se referem principalmente à localização deste, tamanho das unidades habitacionais e qualidade dos acabamentos utilizados.
} 


\section{O PROBLEMA DA AQUISIÇÃO DE HABITAÇÕES ADEQUADAS PELA POPULAÇÃO DE BAIXA RENDA}

O objetivo deste Capítulo é definir e quantificar o problema da aquisição de habitações adequadas pela população de baixa renda, que neste trabalho será considerada como sendo as famílias que ganham até 5 salários mínimos (SM), juntamente com a discussão das principais características desta população que influenciam diretamente na sua capacidade de adquirir habitações adequadas.

Como a maioria do rendimento monetário da população de baixa renda provém do emprego, como será visto no item 3.6.1, que, na maioria dos casos, para esta classe de renda no Brasil, é regulado pelo salário mínimo, e pelo fato de a maioria dos estudos sobre orçamentos familiares desenvolvidos pelo IBGE utilizar o salário mínimo (SM) como referência para separação das classes de rendimento, utilizar-se-á neste trabalho o salário mínimo (SM) como unidade de referência de renda.

\subsection{A população de baixa renda}

Desde 1940, o Brasil tem passado por mudanças que o transformaram em um país predominantemente urbano, dominado por duas grandes metrópoles e um grande número de cidades de tamanho médio. Em 1940, 70\% da população vivia em áreas rurais e 30\% em áreas urbanas, sem grandes alterações até 1960. A partir da década de 1970, este balanço começou a mudar de forma acentuada, tornando o Brasil, no ano 2000, já com 82\% da população vivendo em áreas urbanas, num dos países mais urbanos do mundo. Esta migração da população das áreas rurais para áreas urbanas, que somente em parte foi acompanhada por mudanças econômicas e de desenvolvimento social, juntamente com o aumento acentuado da população, criou grande demanda por habitações nas áreas urbanas e nas periferias das grandes e médias cidades (WORLD BANK, 2002). Pode-se ver na tabela a seguir o crescimento da população e o aumento da concentração da população nas áreas urbanas: 
TABELA 1 : CRESCIMENTO POPULACIONAL E URBANO NO BRASIL

\begin{tabular}{c|c|c|c|c}
\hline \hline Ano & $\begin{array}{c}\text { População } \\
\text { (milhões) }\end{array}$ & $\begin{array}{c}\text { Taxa de } \\
\text { Crescimento } \\
\text { Na Década } \\
\text { (\%) }\end{array}$ & $\begin{array}{c}\text { População em } \\
\text { Áreas Urbanas } \\
\text { (Milhões) }\end{array}$ & $\begin{array}{c}\text { População } \\
\text { Urbana } \\
\text { (\%) }\end{array}$ \\
\hline \hline $\mathbf{1 9 4 0}$ & 41,2 & - & 12,9 & 31,31 \\
\hline $\mathbf{1 9 5 0}$ & 51,9 & 25,97 & 18,8 & 36,22 \\
\hline $\mathbf{1 9 6 0}$ & 70,1 & 35,07 & 31,3 & 44,65 \\
\hline $\mathbf{1 9 7 0}$ & 93,1 & 32,81 & 52,1 & 55,96 \\
\hline $\mathbf{1 9 8 0}$ & 119,0 & 27,82 & 80,4 & 67,56 \\
\hline $\mathbf{1 9 9 0}$ & 146,8 & 23,36 & 111,0 & 75,61 \\
\hline $\mathbf{2 0 0 0}$ & 169,5 & 15,46 & 137,7 & 81,24 \\
\hline \hline
\end{tabular}

Fonte: IPEA, IBGE (2001) apud World Bank (2002)

$\mathrm{O}$ crescimento das grandes e médias cidades trouxe como conseqüência a questão urbana, pois a população mais pobre foi se aglomerando nas periferias das cidades, ocupando áreas de risco, loteamentos geralmente clandestinos e sem infra-estrutura, ocupação ou aluguel de barracos e favelas, ou em cômodos ou cortiços, com invasões de habitações em áreas de proteção ambiental, contribuindo para a deterioração sócio-ambiental urbana (SANDES E MARTINS, 2004).

A população de baixa renda no Brasil é a mais atingida pela dificuldade no acesso à moradia adequada pois, segundo o World Bank (2002), a causa mais importante da existência de necessidades habitacionais no Brasil é a renda insuficiente da maioria da população, seja para a compra, reforma ou aluguel de moradias, seguida da falta da oferta de moradias de pequeno valor no setor formal. A maioria da população brasileira encontra-se dentro da população de baixa renda. Na Tabela a seguir, pode-se ver a distribuição do número famílias pelo rendimento mensal familiar ${ }^{10}$, no Brasil:

\footnotetext{
${ }^{10}$ Segundo o IBGE - PNAD (2005, Notas Técnicas p.14), rendimento mensal familiar (RMF) é "a soma dos rendimentos mensais dos componentes da família, exclusive os das pessoas com menos de 10 anos de idade e os daquelas cuja condição na família fosse pensionista, empregado doméstico ou parente do empregado doméstico".
} 
TABELA 2 : DISTRIBUIÇÃO DA POPULAÇ̃̃O POR FAIXAS DE RENDA NO BRASIL

\begin{tabular}{c|c|c}
\hline \hline $\begin{array}{c}\text { Classes de Rendimento } \\
\text { Rendimento Mensal Familiar (RMF) }\end{array}$ & $\begin{array}{c}\text { Famílias Residentes em } \\
\text { Domicílios Particulares }\end{array}$ & $\begin{array}{c}\text { Percentual } \\
\text { (\%) }\end{array}$ \\
\hline \hline Até 1 SM & 8.520 .387 & 14,84 \\
\hline De 1 a 3 SM & 22.063 .301 & 38,44 \\
\hline De 3 a 5 SM & 10.471 .640 & 18,25 \\
\hline Mais de 5 SM & 13.821 .426 & 24,08 \\
\hline Sem Rendimento & 1.571 .829 & 2,74 \\
\hline Sem Declaração & 948.384 & 1,65 \\
\hline TOTAL & $\mathbf{5 7 . 3 9 6 . 9 6 7}$ & $\mathbf{1 0 0 , 0 0}$ \\
\hline \hline
\end{tabular}

Fonte: IBGE - PNAD (2005).

Pode-se ver que grande parte das famílias brasileiras se enquadra na população de baixa renda, alvo deste trabalho, com rendimentos até 5 SM, correspondendo a 74,27\% das famílias.

\subsection{As necessidades habitacionais da população de baixa renda}

Os critérios necessários para a classificação de uma moradia como adequada podem variar dependendo da situação habitacional, desenvolvimento econômico e cultural de cada país. No Brasil, tendo-se como referência os principais problemas habitacionais enfrentados pelas famílias de baixa renda, que detêm a maioria das necessidades habitacionais, como será visto a seguir, pode-se traduzir os critérios mínimos necessários para classificar-se uma habitação como adequada, pelo apresentado no Capítulo 2, nos seguintes atributos intrínsecos das habitações: regularização da posse da terra; não apresentar deterioração e/ou precariedade de sua estrutura física e fechamentos externos, oferecendo segurança física e proteção aos seus moradores contra umidade, intempéries e risco de contaminação por fatores externos; acesso a redes de esgoto (ou a fossa séptica), drenagem pluvial, água tratada, telefone, eletricidade e iluminação pública; e existência de pelo menos uma unidade sanitária domiciliar interna.

O conceito de moradia adequada, entretanto, é mais abrangente e deve contemplar, além das características intrínsecas de uma habitação, outros fatores, como: limite de densidade, máximo de três moradores por dormitório e apenas uma família por moradia; facilidade de acesso, não pagamento de aluguel e/ou parcela de financiamento habitacional que exceda $20 \%$

\footnotetext{
${ }^{11}$ Particulares são os domicílios destinados à habitação de uma pessoa ou de um grupo de pessoas cujo relacionamento fosse ditado por laços de parentesco, dependência doméstica ou, ainda, normas de convivência.
} 
da renda bruta mensal familiar (parcela média do orçamento das famílias de baixa renda destinada à habitação, como será apresentado no Item 3.5); e integração ao ambiente que a cerca, possibilitando acesso a educação e cultura, lazer, saúde, transporte, segurança pública e coleta de lixo.

No desenvolvimento deste trabalho, entretanto, não se encontrou fontes de pesquisa no Brasil que apresentassem a quantificação de moradias adequadas, ou mesmo de inadequadas, dentro dos parâmetros apresentados, obrigando a pesquisa a tratar esta quantificação de forma simplificada, utilizando dados secundários da Fundação João Pinheiro, que tem como base de dados o PNAD, que trata somente de algumas características das habitações, como integridade física, acesso à infra-estrutura, densidade e acessibilidade.

Para efeito das análises desenvolvidas neste trabalho, portanto, deste ponto em diante da pesquisa, serão consideradas adequadas aquelas moradias que não se enquadram dentro dos parâmetros definidos pela Fundação João Pinheiro (2005) para déficit habitacional e inadequação habitacional, detalhados a seguir. Isto se dará pela inexistência de dados mais abrangentes que informem também o grau de integração das habitações ao ambiente que as cercam, por exemplo.

Segundo a Fundação João Pinheiro-FJP (2005), o déficit habitacional ${ }^{12}$ no Brasil é de 7.902.699 famílias ${ }^{13}$, sendo 6.414.143 famílias urbanas e 1.488.556 famílias rurais, que vivem

12 Déficit habitacional: deficiência do estoque de moradias. Engloba tanto aquelas moradias sem condições de serem habitadas devido à precariedade das construções ou em virtude de terem sofrido desgaste da estrutura física e que devem ser repostas, quanto à necessidade de incremento do estoque decorrente da coabitação familiar ou da moradia em locais destinados a fins não residenciais. O déficit habitacional pode ser entendido, portanto, como déficit pela reposição de estoque e como déficit por incremento de estoque.

O déficit pela reposição do estoque refere-se aos domicílios rústicos. Domicílios rústicos não apresentam paredes de alvenaria ou madeira aparelhada, o que resulta em desconforto para seus moradores e risco de contaminação por doenças, devendo ser repostos.

$\mathrm{O}$ déficit por incremento do estoque refere-se aos domicílios improvisados e à coabitação familiar. $\mathrm{O}$ conceito de domicílios improvisados engloba todos os locais destinados a fins não residenciais que sirvam de moradia, indicando a carência de unidades domiciliares. O conceito de coabitação familiar engloba a soma das famílias conviventes secundárias que vivem junto a outra família em um mesmo domicílio e das que vivem em cômodos cedidos ou alugados.

É considerado também como parte do déficit o ônus excessivo com aluguel, que são as famílias que têm renda familiar até três salários mínimos e gastam com aluguel mais do que $30 \%$ de sua renda. Para famílias com este perfil, seria necessário construir unidades que se adequassem à sua renda familiar. As famílias com renda superior ao limite estipulado acima, entretanto, não foram consideradas pela 
em habitações sem condições de habitabilidade; destas, 6.163 .806 famílias urbanas ${ }^{14}$ (que corresponde a $78 \%$ do déficit total e a $96 \%$ do déficit das famílias urbanas) têm rendimento até $5 \mathrm{SM}$. A seguir pode-se ver a distribuição do déficit habitacional total por tipos de déficit no Brasil:

FIGURA 2 : GRÁFICO DA DISTRIBUIÇÃO DO DÉFICIT HABITACIONAL TOTAL NO BRASIL

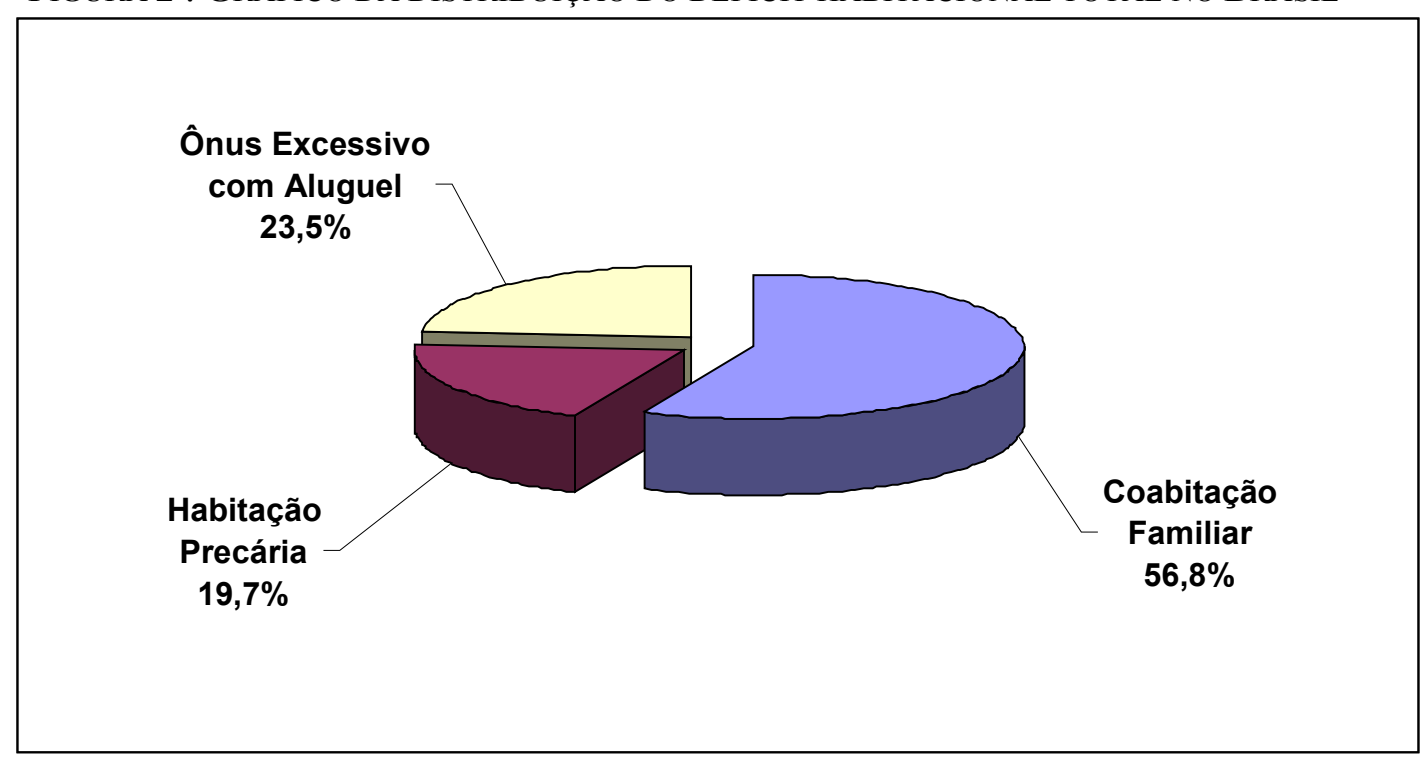

Fonte: Adaptado da Fundação João Pinheiro (2005).

Regionalmente, a distribuição do déficit habitacional no Brasil mostra diferentes cenários para cada região. Em termos relativos, o Nordeste tem o maior déficit habitacional no Brasil, seguido pelo Sudeste, Sul, Centro-oeste e Norte. É importante ressaltar que o Nordeste, embora tenha aproximadamente $26 \%$ das famílias brasileiras e $31 \%$ das famílias de baixa renda, responde por aproximadamente $35 \%$ do déficit habitacional. O gráfico a seguir apresenta a distribuição das famílias, das famílias de baixa renda e do déficit habitacional no Brasil, por regiões:

FJP no déficit por ônus excessivo com aluguel nem por inadequação habitacional (Fundação João Pinheiro, 2005).

${ }^{13}$ O IBGE, na sua Pesquisa Nacional de Amostra por Domicílio - Notas Técnicas (2004, p.5), considera família como "o conjunto de pessoas ligadas por laços de parentesco, dependência doméstica ou normas de convivência, que residissem na mesma unidade familiar e, também, a pessoa que morasse só em uma unidade familiar".

${ }^{14}$ A Pesquisa Nacional de Amostra por Domicílio quantifica as famílias por faixa renda somente para as áreas urbanas. 
FIGURA 3 : GRÁFICO DA DISTRIBUIÇÃO DE FAMÍLIAS, FAMÍLIAS DE BAIXA RENDA E DÉFICIT HABITACIONAL NO BRASIL, POR REGIÕES.

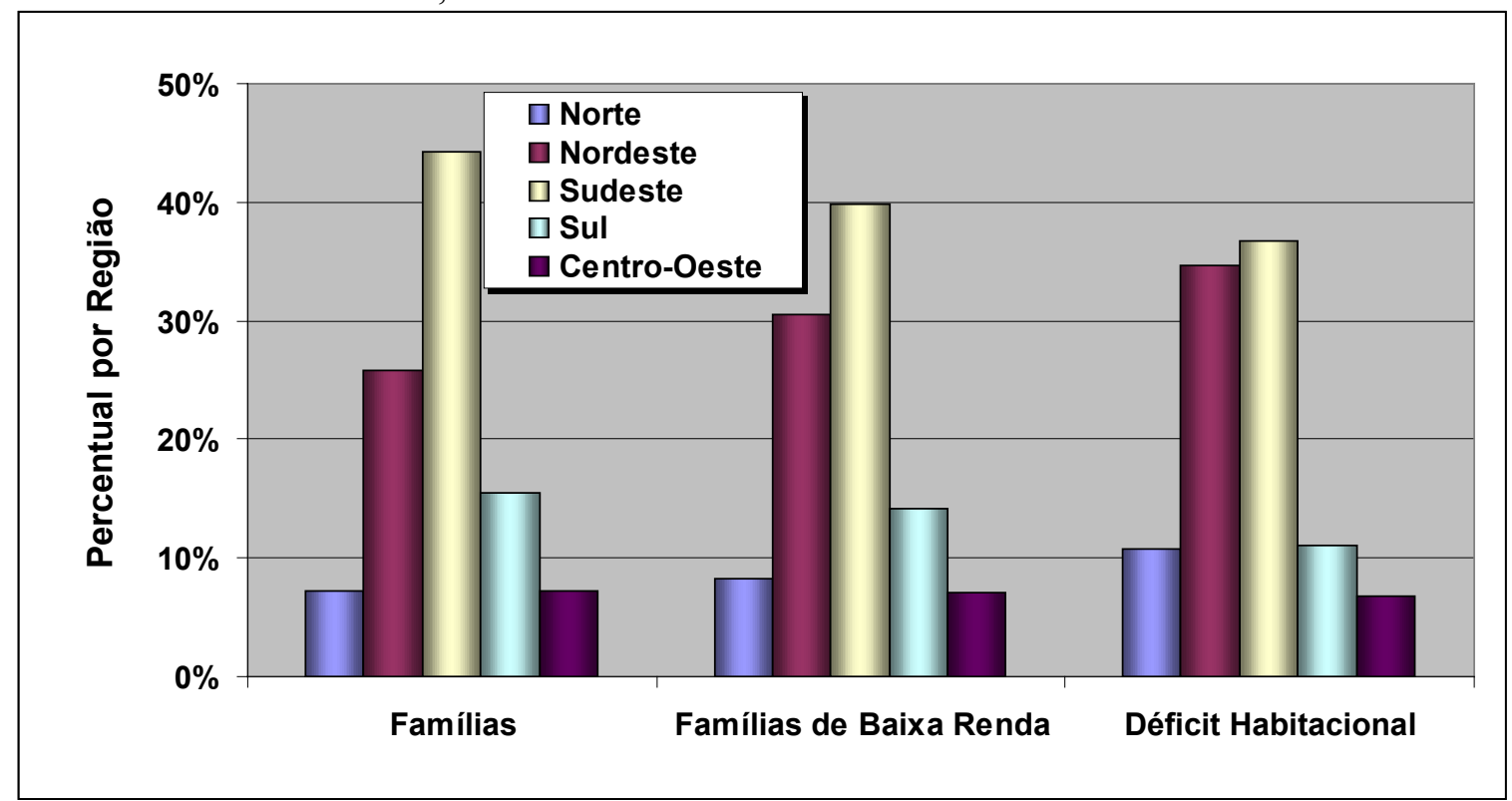

Fonte: Adaptado da Fundação João Pinheiro (2005) e do IBGE - PNAD (2005).

A FJP (2005) aborda, ainda, a questão da inadequação habitacional ${ }^{15}$, um conceito integrante das necessidades habitacionais, que se refere às habitações que não proporcionam aos seus moradores condições desejáveis de habitabilidade, mas não há a necessidade de construção de novas unidades. Para a população de baixa renda, tem-se que: 1.689 .847 famílias moram com adensamento excessivo que se caracteriza por, em média, habitarem mais de três moradores por dormitório; 1.365.864 famílias têm suas habitações com inadequação fundiária/urbana, ou seja, moradias em que pelo menos um dos moradores do domicílio tem a propriedade da moradia, mas não possui total ou parcialmente o terreno ou a fração ideal de terreno (no caso de apartamentos) onde se localiza a moradia; 9.828.716 famílias habitam em moradias que têm carência de serviços de infra-estrutura, pois não dispõem de pelo menos iluminação elétrica, rede geral de abastecimento de água com canalização interna, rede geral de esgoto ou fossa séptica e coleta de lixo; e 1.006.182 famílias vivem em moradias que não têm banheiro ou sanitário para uso exclusivo do domicílio. Vale ressaltar que os números da inadequação habitacional não podem ser somados entre si nem adicionados ao déficit habitacional, pois eles não foram contabilizados com a exclusão dos demais, ou seja, no caso de soma, existirá dupla contagem.

\footnotetext{
${ }^{15}$ Segundo a FJP, a identificação das inadequações habitacionais se atêm somente à área urbana, na qual se concentram mais de $80 \%$ da população brasileira e onde se espera serem maiores as necessidades habitacionais.
} 
A seguir pode-se ver a distribuição do número de inadequações habitacionais da população de baixa renda por tipo de inadequação no Brasil e em seguida a representação da inadequação habitacional da população de baixa renda em relação à inadequação total.

FIGURA 4 : GRÁFICO DA DISTRIBUIÇÃO DO NÚMERO DE INADEQUAÇÕES HABITACIONAIS DA POPULAÇÃO DE BAIXA RENDA NO BRASIL

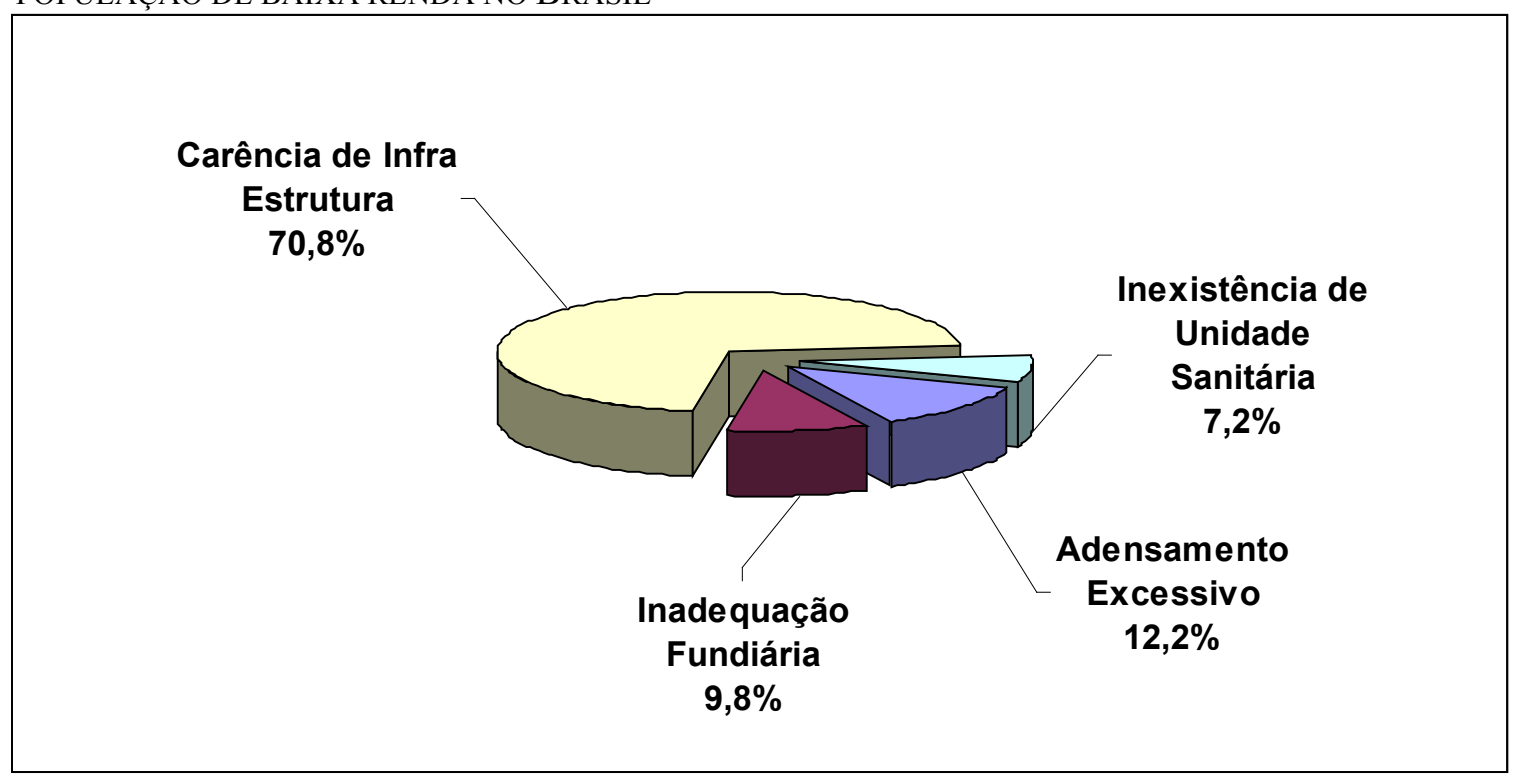

Fonte: Adaptado da Fundação João Pinheiro (2005).

FIGURA 5 : GRÁFICO DA RELAÇÃO ENTRE A INADEQUAÇÃO HABITACIONAL DA POPULAÇÃO DE BAIXA RENDA E A INADEQUAÇÃO HABITACIONAL TOTAL

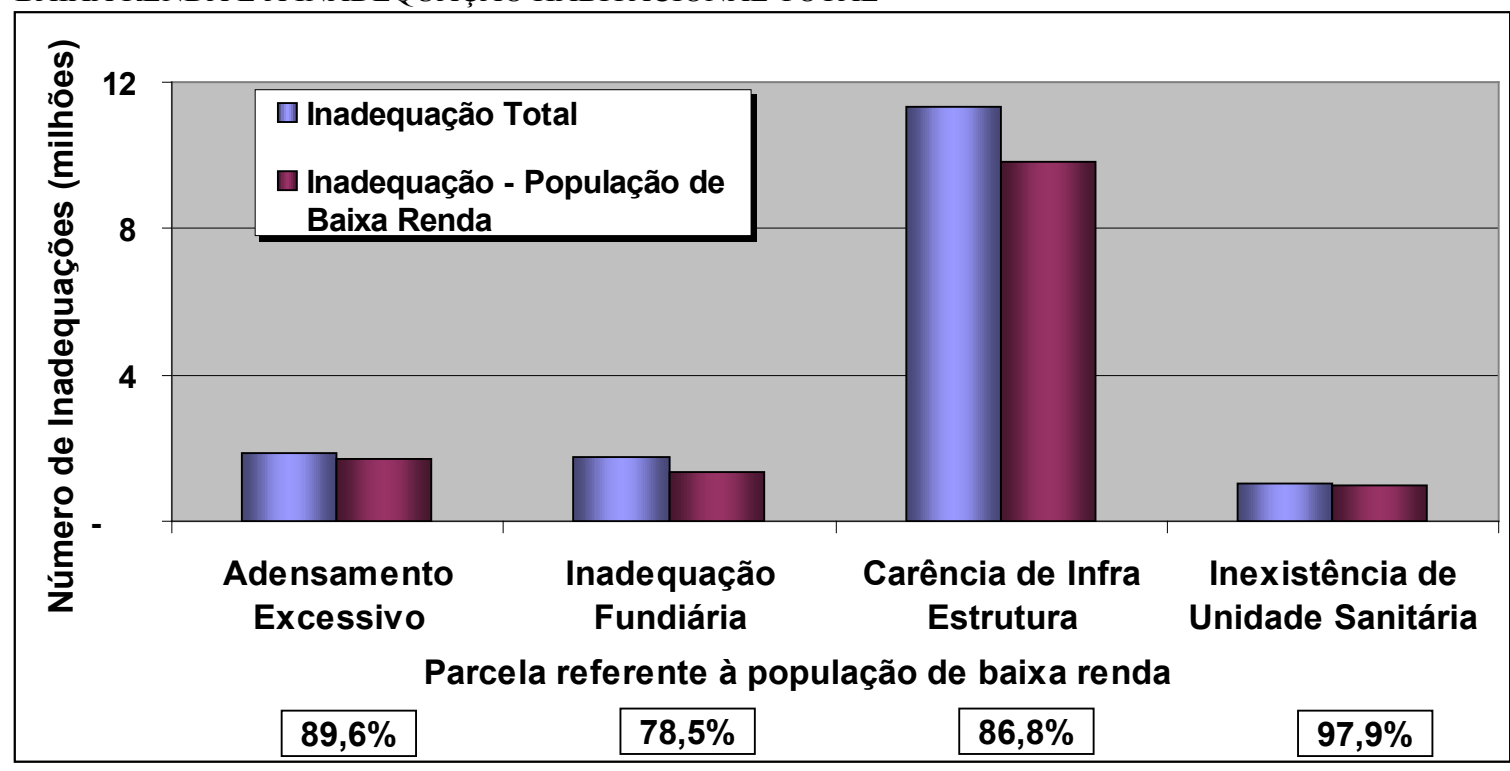

Fonte: Adaptado da Fundação João Pinheiro (2005). 
As inadequações habitacionais, da mesma forma que ocorreu com o déficit habitacional, concentram-se principalmente nas habitações da população de baixa renda e nas habitações localizadas no Nordeste do Brasil (com exceção da inadequação por adensamento excessivo e fundiária). O gráfico a seguir distribui os tipos de inadequação habitacional por regiões:

FIGURA 6 : GRÁFICO DA DISTRIBUIÇÃO DOS TIPOS DE INADEQUAÇÃO HABITACIONAL DA POPULAÇÃO DE BAIXA RENDA, POR REGIÃO

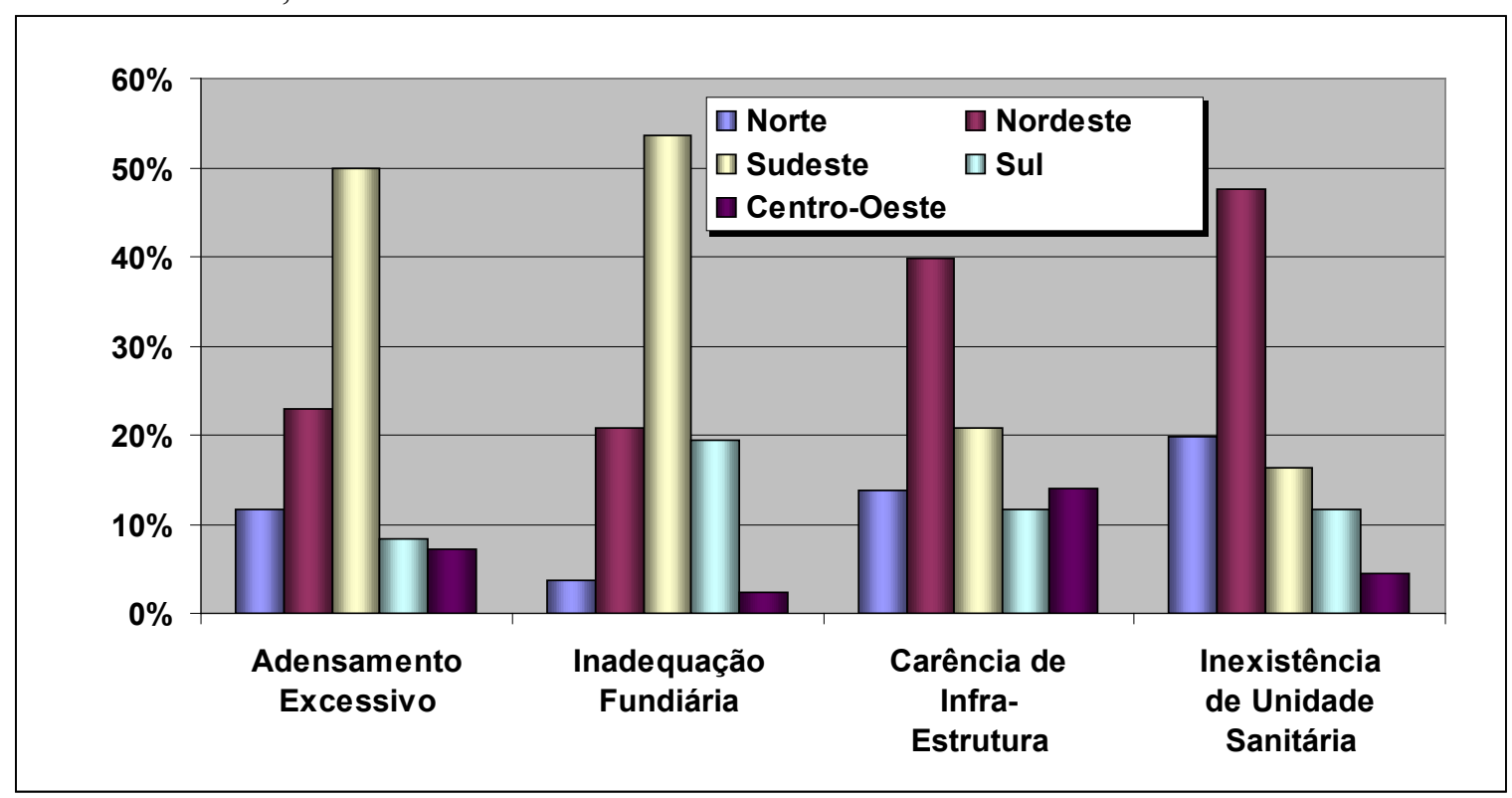

Fonte: Adaptado da Fundação João Pinheiro (2005).

A quantificação das necessidades habitacionais pela FJP indica a necessidade da melhoria do estoque de habitações ocupadas, seja pelo incremento de novas unidades ou pela melhoria das unidades existentes e, conseqüentemente, indica o número de famílias que vivem em condições não adequadas no Brasil. O PNAD (2005), entretanto, que a Fundação João Pinheiro toma como principal referência neste estudo, pesquisa somente os domicílios ocupados, ou seja, não analisa a quantidade de domicílios desocupados e suas condições de habitabilidade. Isto pode ocasionar um viés nos resultados obtidos, pois as habitações adequadas desocupadas não são deduzidas do número de moradias que necessitam ser repostas ou reformadas, como encontrado pela FJP. Estas moradias, em condições de habitabilidade, podem estar desocupadas por dificuldade de acesso da população e não pela necessidade de produção de novas moradias ou reforma das existentes.

Vale ressaltar que, segundo a FJP (2005), existem 6,7 milhões de domicílios vagos no Brasil, sobre os quais não existem informações qualitativas. O Ministério das Cidades (2004) assinala 
que “[...] esses imóveis não estão, necessariamente, ajustados à demanda habitacional tanto no que se refere à adequação para moradia como para atendimento aos grupos sociais mais carentes, com baixos rendimentos, que é onde se concentra o maior déficit habitacional."

A melhoria e ampliação do estoque de moradias não necessariamente significam a melhoria nas condições habitacionais da população de baixa renda, pois, se não existirem formas que façam com que esta população possa pagar o preço das novas unidades ou a reforma das existentes, a situação de desequilíbrio permanecerá, ou se tornará pior, mesmo com a melhoria e ampliação do estoque. Portanto, existem diversas razões para a atual situação habitacional brasileira, sendo uma das causas principais a junção entre a baixa renda de uma grande parcela da população com a falta de financiamentos adequados que possam possibilitar a aquisição ou a reforma de moradias para esta população. Segundo o World Bank (2002), as principais causas para o déficit e inadequação habitacional presentes no Brasil são:

- $\quad$ os baixo níveis de renda - o maior obstáculo para se ter acesso à moradia pela população de baixa renda no Brasil é a falta de poder de compra;

- altos custos da oferta - no mercado formal, o preço da menor habitação popular é alto em comparação com o poder de compra da população de baixa renda e os financiamentos habitacionais disponíveis para este público;

- falhas do mercado - regulamentações de uso da terra e da construção, juntamente com monopólios de propriedade da terra e da indústria da construção, não deixam que os preços das habitações caiam;

- $\quad$ distorções em políticas públicas - desde o colapso do BHN, o setor público no Brasil tem feito esforços limitados nas intervenções habitacionais. Esta atitude tem provocado diversas conseqüências, como falta de coordenação das políticas habitacionais por meio dos diversos níveis governamentais; papel limitado do Governo Federal em lidar com vários aspectos do problema habitacional, principalmente $\mathrm{o}$ uso da terra $\mathrm{e}$ regulamentação da construção; papel limitado do Governo Federal em direcionar financiamentos para a população de baixa renda; gastos em habitação beneficiam principalmente as famílias de média renda; poucos programas são direcionados aos mais pobres e os que existem não têm escala suficiente para atingir uma parcela significante 
destes; e são escassas as terras servidas de infra-estrutura. Sempre preocupados no reforço de regulamentações de zoneamento e construção, os governos falham no planejamento e na oferta de terras servidas de infra-estrutura, proporcionalmente ao crescimento da população.

\subsection{O crescimento do número de famílias de baixa renda}

No Brasil, o número de famílias com renda mensal até 3SM tem apresentado os maiores índices de crescimento, o que tende a agravar o déficit habitacional, por ser a parcela da população que mais precisa de subsídios para ter acesso à habitação adequada. Já o número de famílias com renda de mais de 3SM até 5SM e com renda acima de 5SM têm se mantido perto da estabilidade, como pode ser constatado pelo gráfico a seguir:

FIGURA 7: GRÁFICO DA EVOLUÇÃO DO NÚMERO DE FAMÍLIAS NO BRASIL, POR FAIXAS DE RENDA

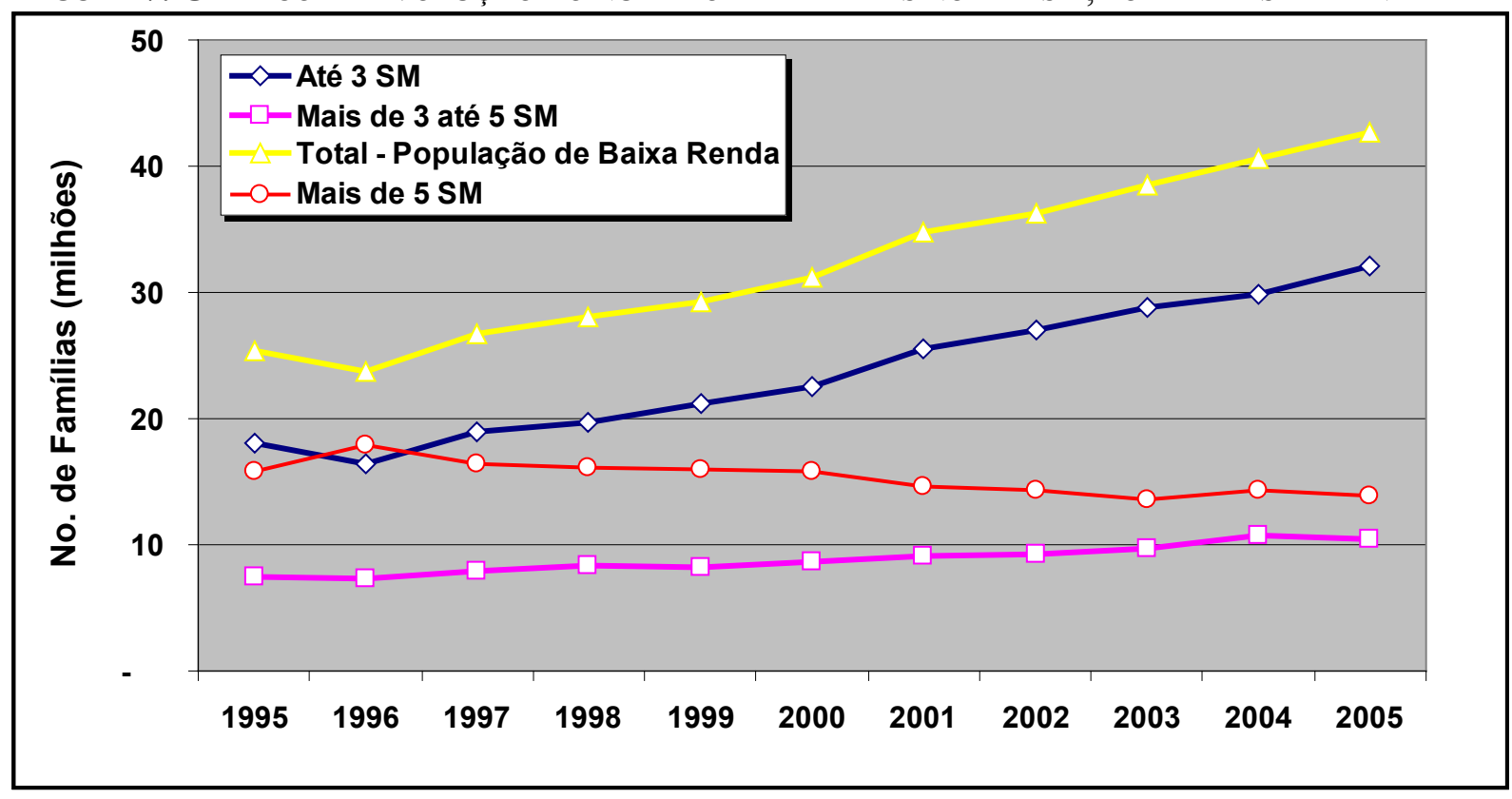

Fonte: IBGE, PNAD (1995 a 2005)

Em 2000, o ano de realização do Censo do IBGE, não foi realizado o PNAD. Os valores do ano 2000 representados neste trabalho foram projetados com base nos PNAD's de 1995 a 2005. 


\subsection{As necessidades habitacionais e a demanda efetiva por habitações}

Segundo Grimes Jr. (1976), o conceito de necessidade habitacional ordinariamente se limita à análise da necessidade de moradias adequadas, sem considerar se as famílias podem ou não pagar o preço da habitação. Para tal, definem-se padrões estruturais mínimos de qualidade, como os que foram estabelecidos pela Fundação João Pinheiro em seu estudo sobre necessidades habitacionais. Em contrapartida, a demanda efetiva por habitações é caracterizada pela vontade de cada família em adquirir, reformar ou alugar uma moradia e de, principalmente, ter a capacidade de pagar o seu preço, mesmo que seja mediante financiamento, no caso de aquisição e reforma. Cada família determina as prioridades dentro do seu orçamento familiar, inclusive a parcela destinada à habitação. Fatores como o nível e a distribuição de renda disponível, o preço das habitações, os financiamentos e os preços de outros produtos e serviços são determinantes na decisão de cada família de quanto será destinado à habitação dentro do seu orçamento.

A quantificação das necessidades habitacionais da população de baixa renda desenvolvida pela Fundação João Pinheiro é hoje o estudo existente mais relevante para se definir a quantidade desta população que não vive em moradias adequadas, embora não represente a demanda efetiva por moradias. Este estudo define a quantidade de famílias que vivem em condições inadequadas no Brasil e que, caso existissem financiamentos adequados, provavelmente, na sua maioria, se tornariam demanda efetiva. Portanto, neste trabalho, considerar-se-á que, uma vez que existam financiamentos habitacionais adequados, na forma e no tamanho, que possibilitem o acesso dessas famílias de baixa renda a habitações adequadas, estas famílias se tornarão demanda efetiva.

Bolaffi $^{16}$ (1979 apud Coelho, 2002, p.57) assinala que "[...] na sociedade capitalista a demanda por habitações é apenas a demanda solvável, constituída pelos indivíduos que podem pagar o seu preço".

\footnotetext{
${ }^{16}$ BOLAFFI, G. Habitação e urbanismo: o problema e o falso problema. In: MARICATO, E.A. Produção capitalista da casa e da cidade no Brasil industrial. São Paulo:Alfa-Omega.1979.
} 


\subsection{O orçamento familiar e a parcela do rendimento destinada à habitação}

A distribuição do orçamento familiar entre despesas totais ${ }^{17}$, despesas com habitação, aumento de ativo e diminuição de passivo da população de baixa renda no Brasil, segundo o IBGE, na pesquisa de orçamentos familiares (2002/2003), tem a seguinte composição:

TABELA 3 : DISTRIBUIÇÃO DO ORÇAMENTO FAMILIAR DA POPULAÇÃO DE BAIXA RENDA

\begin{tabular}{c|c|c|c}
\hline \multirow{2}{*}{ Itens do Orçamento Familiar } & \multicolumn{3}{|c}{ Classes de Rendimento } \\
\cline { 2 - 4 } & Até 2SM & De 2SM a 3SM & De 3SM a 5SM \\
\hline Habitação $^{(1)}$ & $19,70 \%$ & $20,25 \%$ & $20,98 \%$ \\
\hline Despesas Gerais do Lar $^{(2)}$ & $19,88 \%$ & $19,06 \%$ & $18,27 \%$ \\
\hline Alimentação & $32,68 \%$ & $29,76 \%$ & $25,44 \%$ \\
\hline Vestuário & $5,29 \%$ & $5,70 \%$ & $5,80 \%$ \\
\hline Transporte & $6,49 \%$ & $6,71 \%$ & $8,00 \%$ \\
\hline Higiene e Cuidados Pessoais & $2,40 \%$ & $2,37 \%$ & $2,35 \%$ \\
\hline Assistência e Saúde & $4,08 \%$ & $4,66 \%$ & $4,95 \%$ \\
\hline Educação, Recreação e Cultura & $1,61 \%$ & $2,10 \%$ & $2,67 \%$ \\
\hline Serviços Pessoais & $0,64 \%$ & $0,68 \%$ & $0,78 \%$ \\
\hline Aumento de Ativo ${ }^{(3)}$ & $1,69 \%$ & $1,91 \%$ & $2,96 \%$ \\
\hline Diminuição de Passivos & $0,39 \%$ & $0,33 \%$ & $0,43 \%$ \\
\hline Despesas Diversas & $5,15 \%$ & $6,45 \%$ & $7,37 \%$ \\
\hline \hline
\end{tabular}

Fonte: Adaptado do IBGE - Pesquisa de Orçamentos Familiares 2002/2003.

${ }^{(1)}$ Em Habitação, estão inclusas as despesas com aluguel, aquisição e reforma de habitações.

${ }^{(2)}$ Foram considerados em Despesas Gerais do Lar os itens: serviços e taxas, manutenção do lar, artigos de limpeza, mobiliários, eletrodomésticos e consertos artigos do lar.

${ }^{(3)}$ Em Aumento de Ativo estão inclusos aquisição de veículos e outros investimentos.

Pela Tabela anterior, pode-se ver que, para a população de baixa renda, a maior parcela do orçamento familiar destina-se à alimentação, ficando entre $25,44 \%$ e $32,68 \%$ do orçamento. A despesa com habitação, que para as três faixas de renda estudadas estão perto de $20 \%$ do orçamento em média, é a segunda maior despesa do orçamento familiar, tendo pesos semelhantes nos orçamentos para as três faixas de renda estudadas.

\footnotetext{
${ }^{17}$ Compõem as despesas totais todas as despesas monetárias e não monetárias correntes (despesas de consumo e outras despesas correntes).
} 
Malpezzi, Mayo e Gross (1985) desenvolveram um estudo junto ao World Bank, no qual analisaram o comportamento da demanda por habitações em países em desenvolvimento. Esse estudo examinou 14 cidades $^{18}$ de países diferentes, focando principalmente no comportamento do percentual da renda familiar destinado à habitação. Chegaram a algumas conclusões comuns às cidades pesquisadas, como segue:

- o comportamento do percentual de renda destinado à habitação tem padrões similares para as diversas cidades pesquisadas;

- a população de renda mais baixa destina um percentual maior de sua renda à habitação, em comparação com as classes de maior renda;

- $\quad$ nos países mais desenvolvidos, o percentual destinado à habitação, para uma mesma faixa de renda, é maior do que nos países menos desenvolvidos;

- $\quad$ com o crescimento econômico, a população tende a destinar um percentual maior de sua renda à habitação; e

- $\quad$ a elasticidade do percentual da renda destinado à habitação relativamente à variação da renda tem comportamentos diferentes no curto, médio e longo prazos. Para a população de baixa renda, o percentual da renda destinado à habitação, inicialmente, não cresce proporcionalmente com o crescimento da renda. Habitação é uma das necessidades básicas, mas, para a população de baixa renda, o aumento da renda tende a migrar inicialmente para melhorar outras necessidades ainda mais básicas, como alimentação, saúde, vestuário etc., antes da habitação. Com a continuação do aumento da renda, o crescimento do percentual da renda destinado à habitação tende a se aproximar do aumento da renda. Isto significa dizer que, com o aumento da renda familiar, para a população de baixa renda, no curto prazo, o crescimento do percentual da renda destinado à habitação se mostra inelástico, enquanto no médio e longo prazos ele tende a se tornar mais elástico.

\footnotetext{
${ }^{18}$ As 14 cidades pesquisadas neste estudo foram: Bogotá e Cali, na Colômbia; Beni Suef e Cairo, no Egito; Santa Ana e Sonsonate, em El Salvador; Bangalore, na Índia; Busane, Kwangju, Seoul, Taegu e Oth. K.C., na Coréia; e Davao e Manila, nas Filipinas.
} 
No Brasil, como nos países pesquisados por Malpezzi, Mayo e Gross (1985), pode-se ver que a população de renda mais baixa destina uma parcela maior de sua renda para habitação, em comparação com a população de renda mais alta. Para a população com renda até 3SM, contudo, pode-se ver pelo gráfico a seguir que o percentual da renda destinado à habitação cresce com o crescimento da renda, mostrando-se elástico, e começando a cair para a população com renda acima de 5SM. Novamente, diferentemente do estudo ora citado, com a continuação do crescimento da renda, o percentual da renda destinado à habitação continua a cair, mostrando-se inelástico, comportamento este que começa a se reverter para a população com renda acima da faixa de 15 a 20 SM.

FIGURA 8: GRÁFICO DO PERCENTUAL DO RENDIMENTO FAMILIAR DESTINADO À HABITAÇÃO, POR CLASSES DE RENDIMENTO NO BRASIL

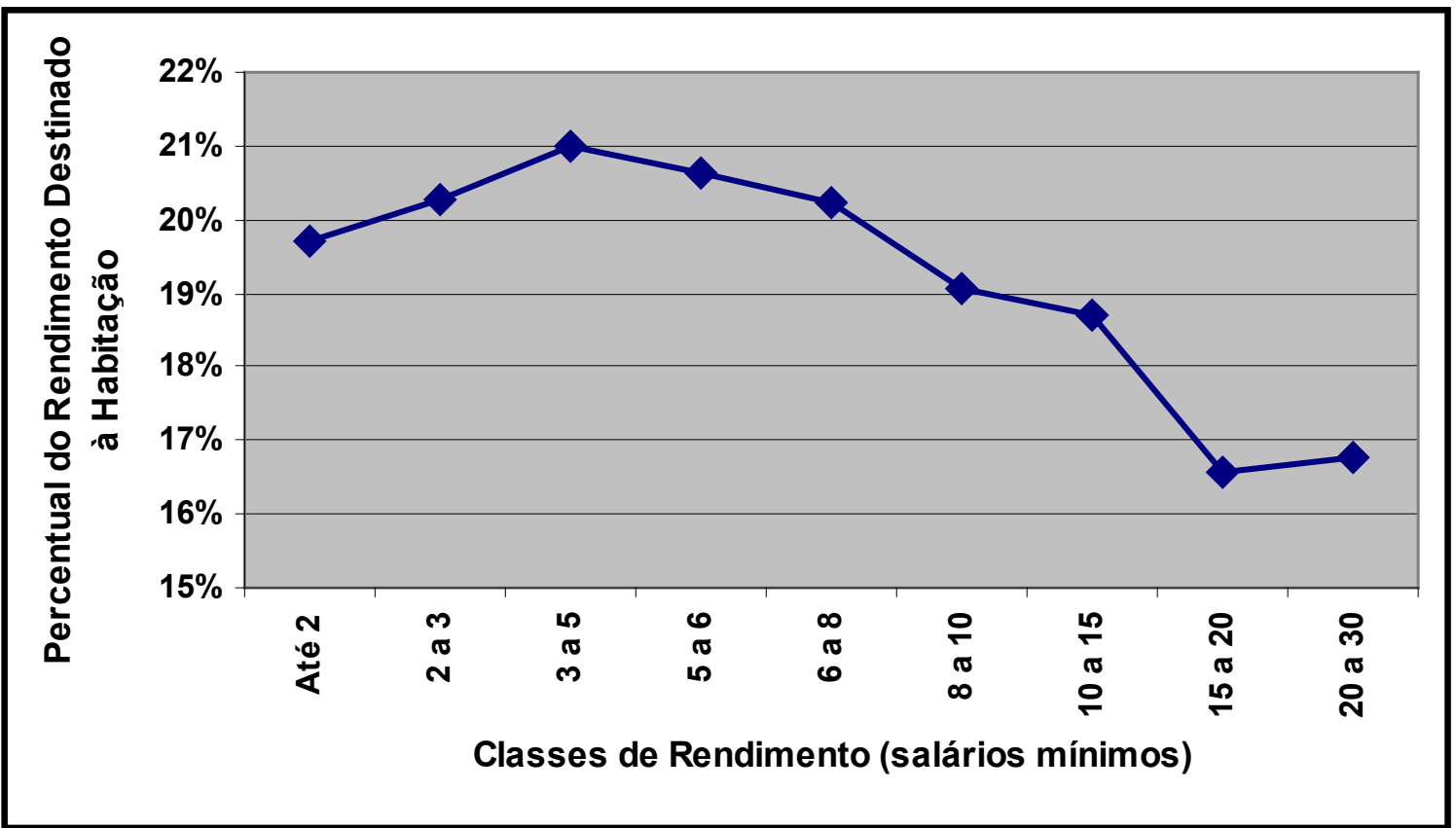

Fonte: Adaptado do IBGE - Pesquisa de Orçamentos Familiares 2002/2003. 


\subsection{Análise da capacidade da população de baixa renda de pagar o preço da habitação}

\subsubsection{A origem dos rendimentos}

A maioria da população de baixa renda obtém seu rendimento monetário por intermédio do trabalho como empregado, seguido por transferência de renda ${ }^{19}$ e trabalho por conta-própria, como pode ser visto no gráfico a seguir.

FIGURA 9: GRÁFICO DA ORIGEM DOS RENDIMENTOS MONETÁRIOS, POR CLASSES DE RENDIMENTO

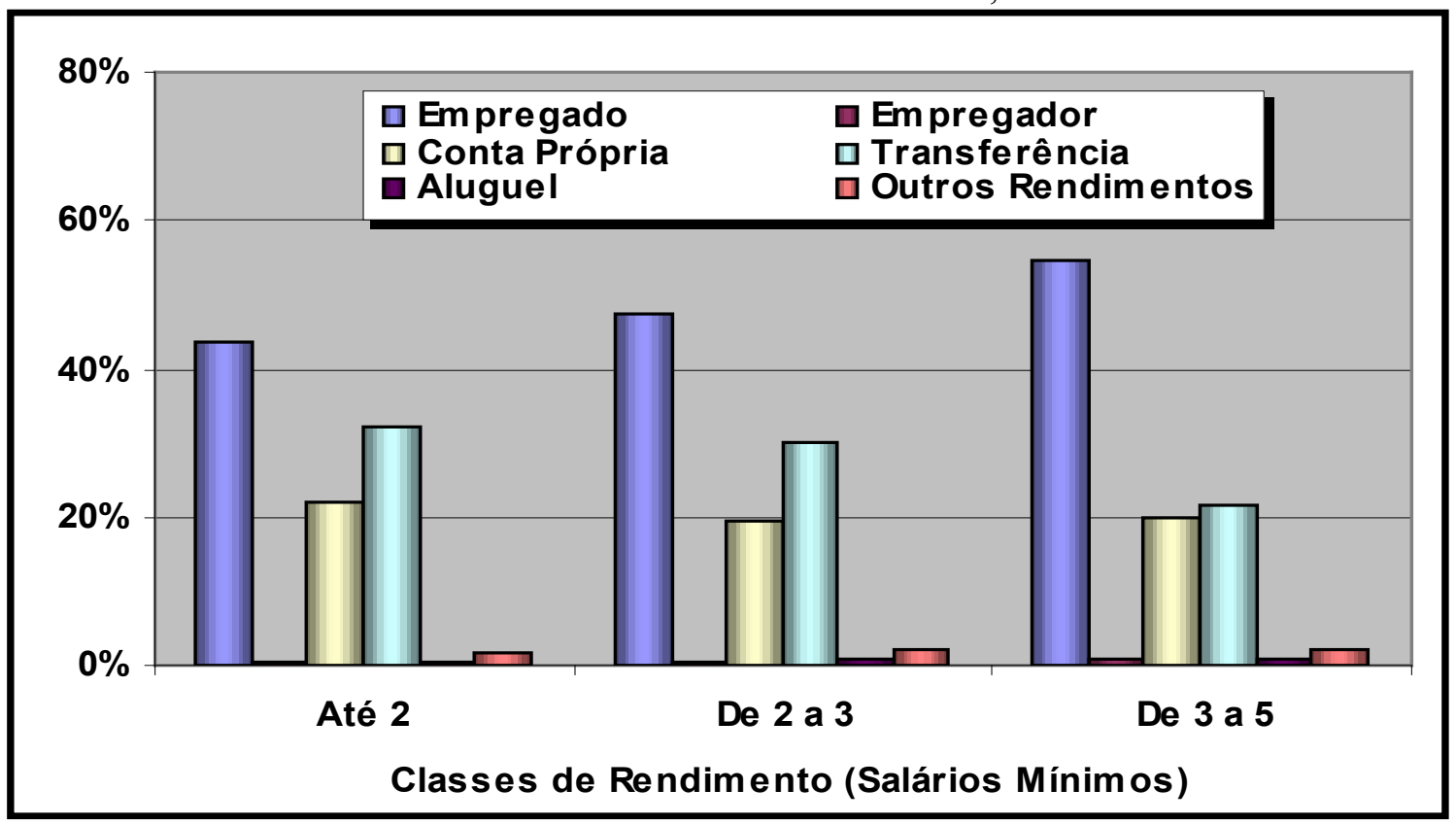

Fonte: Adaptado do IBGE, Pesquisa de Orçamentos Familiares (2002/2003)

\subsubsection{O descolamento entre a evolução do rendimento e o crescimento dos preços da habitação}

O valor do salário mínimo e o valor da habitação têm parâmetros de reajuste diferentes. O salário mínimo é estabelecido pelo Governo Federal, no começo de cada ano, com base na inflação do ano anterior, agregado de um ganho de poder de compra que é decidido politicamente, e o valor da habitação obedece a flutuações dos valores das matérias-primas e da mão-de-obra da construção civil, de acordo com o mercado, juntamente com a evolução do

\footnotetext{
${ }^{19}$ Transferência de renda é o rendimento monetário bruto proveniente de aposentadoria de previdência pública e privada, bolsa de estudos, pensão alimentícia, mesada, doação e transferências transitórias. (IBGE, Pesquisa de Orçamentos Familiares, 2002/2003 - Notas Técnicas).
} 
valor da terra. O resultado é que muitas vezes o valor do salário mínimo se descola do valor da habitação. Com o objetivo de representar este descolamento, fez-se uma progressão histórica entre os reajustes do salário mínimo e o reajuste do $\mathrm{INCC}^{20}$ - Índice Nacional de Custos da Construção Civil, que representa as variações nos custos das matérias-primas e da mão-de-obra da construção civil, parcela expressiva dos custos da habitação. Com o objetivo de também representar o descolamento entre os outros itens do orçamento familiar, que não são habitação, e o salário mínimo, fez-se também uma progressão histórica entre o reajuste do INPC $^{21}$ - Índice Nacional de Preços ao Consumidor, que utiliza como base de suas amostras a população com faixas de rendimento próximas às estudadas neste trabalho, e o salário mínimo. A progressão histórica descrita inicia-se em 1996, de forma a coincidir com a penúltima pesquisa de orçamentos familiares feita pelo IBGE, possibilitando, assim, detectarse possíveis razões para mudanças na distribuição dos orçamentos familiares, como será visto a seguir.

\section{FigURA 10: GRÁFICO DA EVOLUÇÃO DO SALÁRIO MÍNIMO, INCC E INPC}

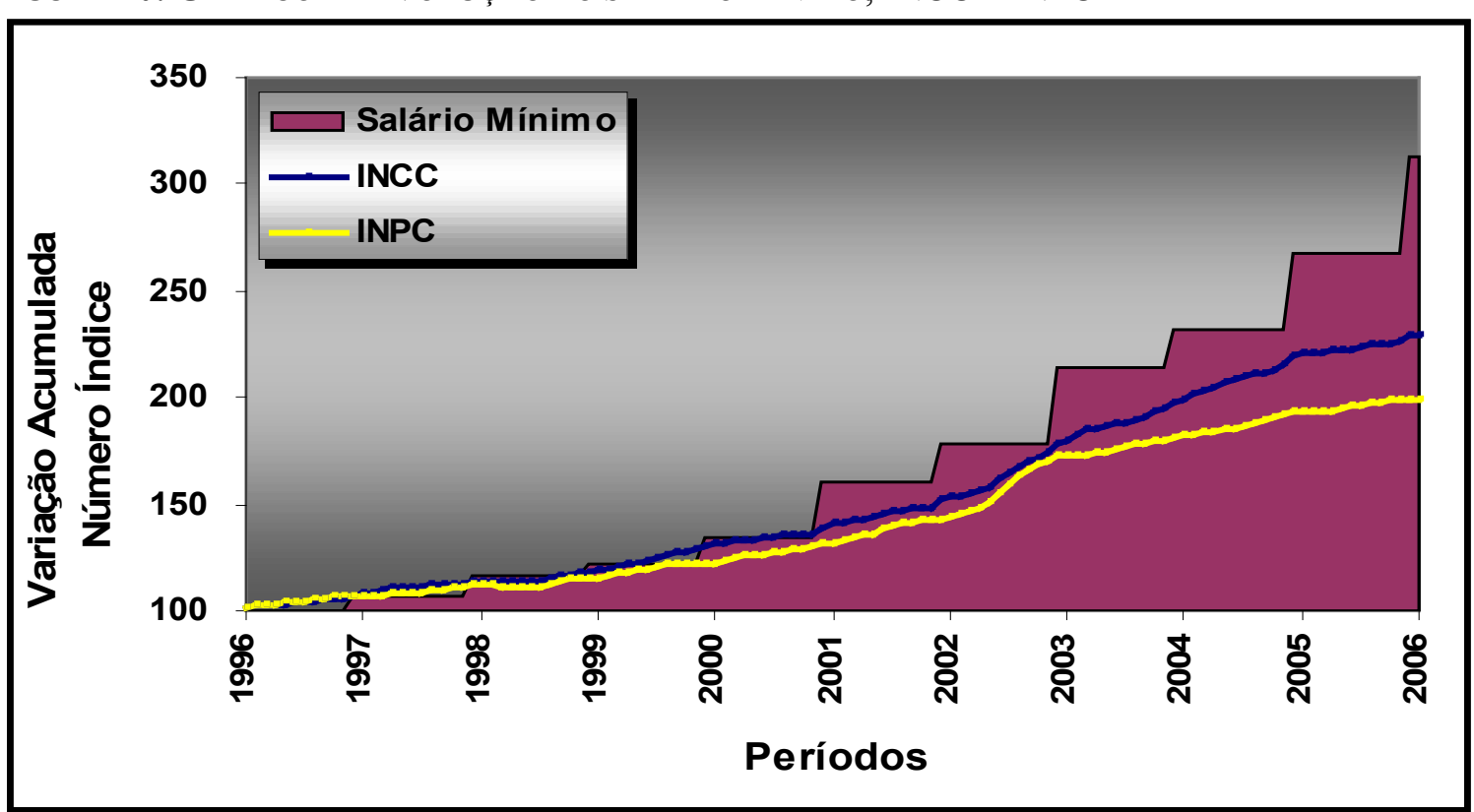

Fontes: IBGE e FGV.

Considerou-se cada período de 12 meses se iniciando em junho e terminando em maio do ano descrito, de forma a coincidir, aproximadamente, com o reajuste do salário mínimo.

\footnotetext{
${ }^{20}$ Tem a finalidade de aferir a evolução dos custos de construções habitacionais. A estrutura de custos é composta de 51 tipos de materiais e 16 categorias de mão-de-obra, levando-se em consideração padrões específicos de construções habitacionais (FGV. Disponível em: <www.fgv.br>, acesso em: 20 ago. 2006).

${ }^{21}$ A população-objetivo do INPC é referente às famílias com rendimentos mensais compreendidos entre 1(hum)e 8(oito) salários-mínimos, cujo chefe é assalariado em sua ocupação principal e residente nas áreas urbanas das regiões (IBGE. Disponível em: <www.ibge.gov.br>, acesso em: 20 ago. 2006).
} 
Pode-se ver pelo gráfico anterior que o reajuste acumulado do salário mínimo, a partir de 2001, se manteve acima dos reajustes acumulados do INCC e do INPC. Isto mostra um ganho no poder de compra da população, tanto para a aquisição de habitações como para a compra de outros bens de consumo que fazem parte do orçamento familiar. Antes de 2001, porém, os reajustes do salário mínimo mantiveram-se menores do que a perda inflacionária medida pelo INCC. O objetivo desta análise, neste momento do texto, é somente de destacar o descasamento dos valores apresentados, sem a intenção de pesquisar períodos específicos.

\subsubsection{A evolução da distribuição das despesas familiares da população de baixa renda}

Os resultados das Pesquisas de Orçamentos Familiares desenvolvidas pelo IBGE nos períodos de $1995 / 1996^{22}$ e 2002/2003, representados nos gráficos a seguir, permitem identificar as tendências de dispêndio com habitação da população de baixa renda no Brasil. Segundo Castro e Magalhães (1998, p.25),

[...] a estrutura de dispêndio é afetada, em geral, por fatores ligados à variação da renda e sua distribuição; aos padrões demográficos e educacionais; aos preços relativos dos bens e à capacidade do setor público em prover bens em quantidade e qualidade suficiente para o atendimento das necessidades das famílias. Em suma, as mudanças na estrutura de consumo familiar devem ser analisadas com cuidado, devido à complexidade de fatores que afetam a restrição orçamentária das famílias, $e$ sua estrutura de preferência.

${ }^{22}$ A Pesquisa de Orçamentos Familiares de 1995/1996 abrangeu o perímetro urbano das regiões metropolitanas de Belém, Fortaleza, Recife, Salvador, Belo Horizonte, Rio de Janeiro, São Paulo, Curitiba e Porto Alegre, além do Distrito Federal e o Município de Goiânia, enquanto a POF de 2002/2003 abrangeu o País inteiro, inclusive as áreas rurais. 
FIGURA 11 : GRÁFICO DA PARCELA DO ORÇAMENTO FAMILIAR DESTINADA À HABITAÇ̃̃O PELA POPULAÇ̃̃O DE BAIXA RENDA - 1995/1996 E 2002/2003

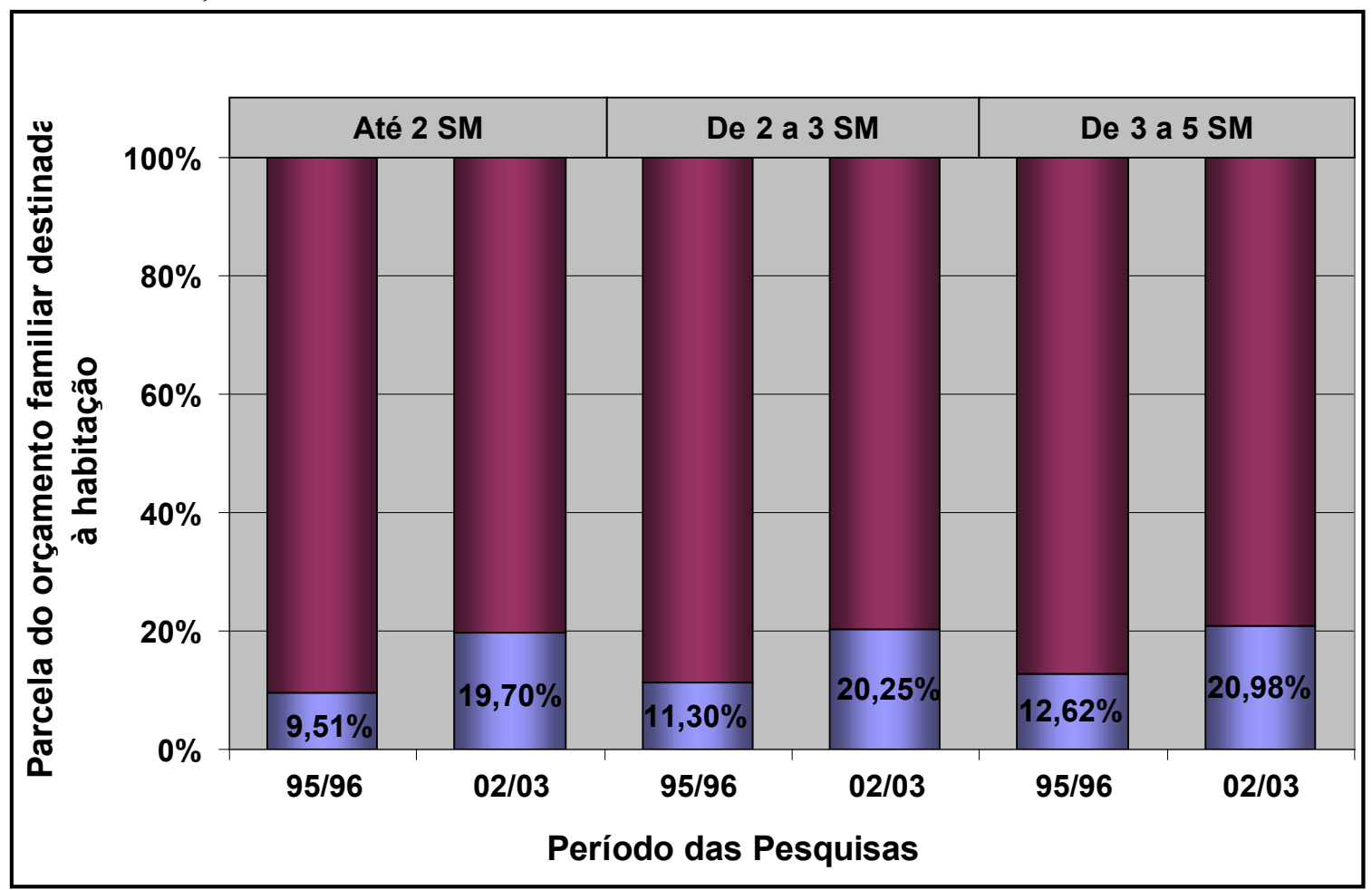

Fonte: Adaptado do IBGE, Pesquisas de Orçamentos Familiares, 2002/2003 e 1995/1996.

Em Habitação estão inclusas as despesas com aluguel, aquisição e reforma de habitações.

Pode-se ver no gráfico anterior que a parcela do orçamento familiar destinada à habitação cresceu acentuadamente para as três faixas de renda estudadas, chegando a dobrar de valor na faixa até $2 \mathrm{SM}$. Isto decorre do fato de que o percentual médio de despesas com aluguel praticamente triplicou para os três casos, causando esta variação. A parcela do orçamento familiar destinada à aquisição de habitações aumentou para as faixas de rendimento até 2 SM e de 3 a 5 SM, enquanto diminuiu para a faixa de 2 a 3 SM. Pode-se ver pelo gráfico a seguir a evolução da parcela do orçamento familiar destinada à habitação, por tipo de utilização. 
FIGURA 12 : GRÁFICO DA EVOLUÇÃO DO RENDIMENTO FAMILIAR DESTINADO À HABITAÇÃO, POR TIPO DE UTILIZAÇÃO - 1995/1996 E 2002/2003

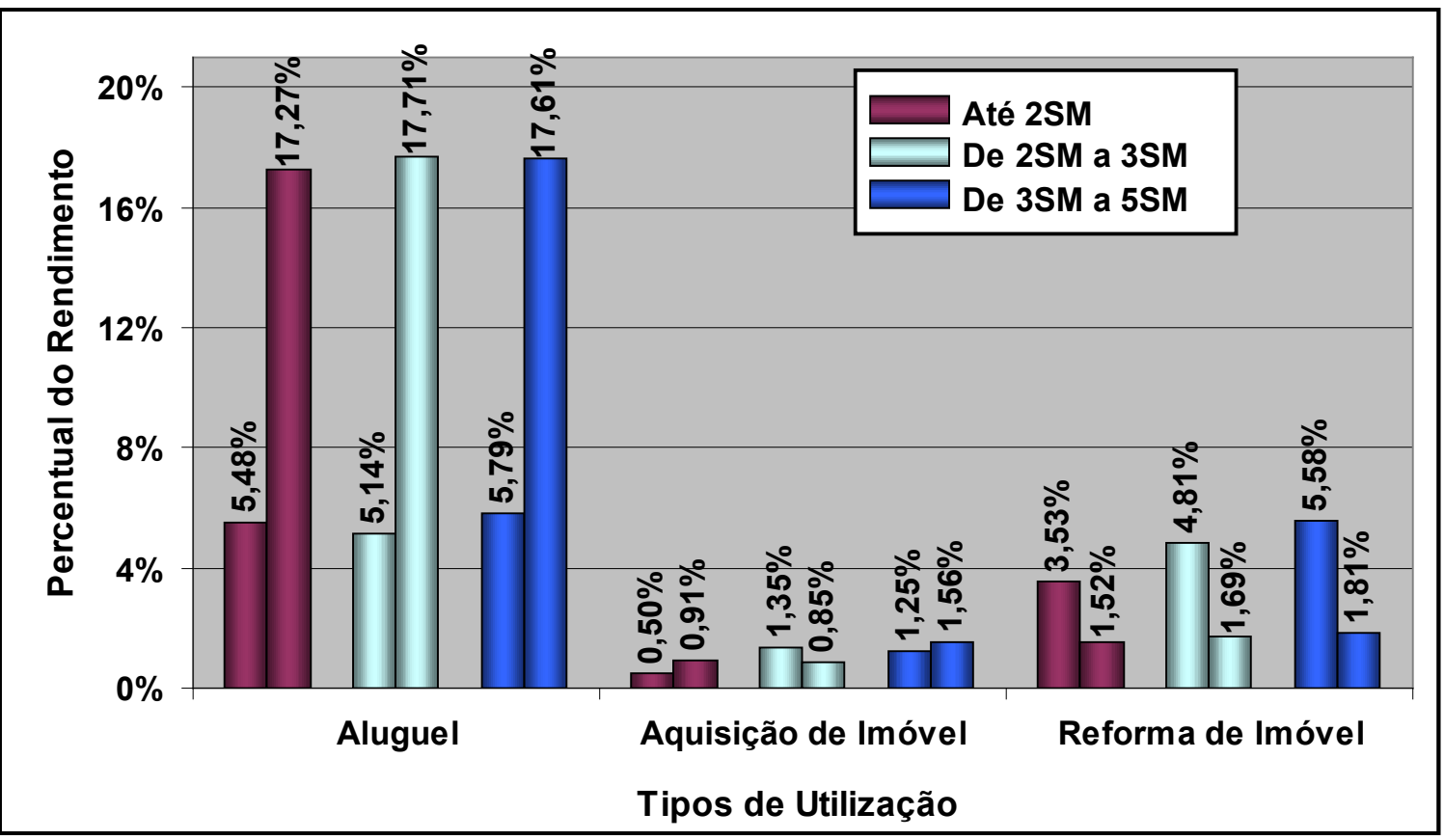

Fonte: Adaptado do IBGE, Pesquisas de Orçamentos Familiares, 2002/2003 e 1995/1996 As parcelas do orçamento familiar destinadas à aquisição de imóveis e prestação de imóveis foram agrupadas em aquisição de imóveis.

A migração de parte do orçamento familiar para habitação teve como fontes principais os itens alimentação, assistência e saúde, educação, recreação e cultura, transporte e serviços pessoais, que tiveram seus percentuais do orçamento familiar diminuídos. Para as faixas de rendimento de 2 a $3 \mathrm{SM}$ e de 3 a $5 \mathrm{SM}$, houve diminuição nos percentuais do orçamento familiar destinados à alimentação, enquanto para a faixa de rendimento até 2 SM este percentual se manteve estável. Para os itens assistência e saúde, educação, recreação e cultura, transporte e serviços pessoais, houve diminuição significativa nos percentuais dessas despesas no orçamento familiar para as três faixas de renda estudadas. O ganho real de poder de compra do salário mínimo, como demonstrado no item 3.6.2, pode ter compensado as diminuições nos percentuais dessas despesas no orçamento familiar, onde podem ter sido mantidos os mesmos níveis de qualidade alimentar ou educacional para um percentual menor do orçamento familiar, por exemplo.

Embora o percentual do orçamento familiar destinado à habitação esteja em torno de $20 \%$, em média, para a população de baixa renda no Brasil, ao analisar-se o orçamento familiar regionalmente pelo gráfico a seguir, pode-se ver que a região Sudeste é a que destina parcela maior do orçamento familiar da população de baixa renda para habitação, seguida pelas 
regiões Sul e Centro-oeste, enquanto as regiões Norte e Nordeste destinam percentuais menores do orçamento familiar.

FIGURA 13 : GRÁFICO DA PARCELA DO ORÇAMENTO FAMILIAR DESTINADA À HABITAÇÃO PELA POPULAÇÃO DE BAIXA RENDA, POR REGIÃO - 2002/2003

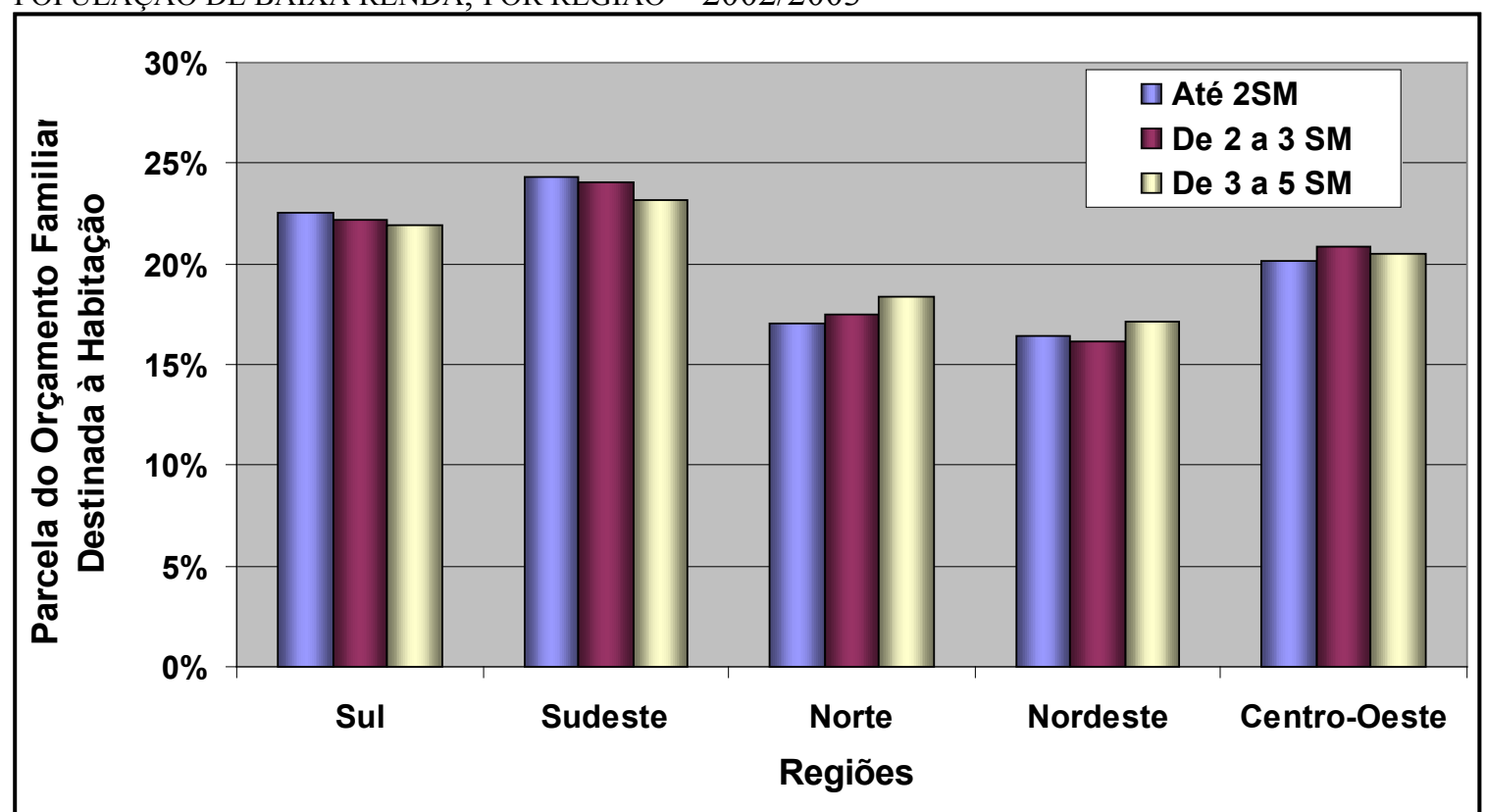

Fonte: Adaptado do IBGE, Pesquisas de Orçamentos Familiares 2002/2003

De forma geral, houve redução do crescimento patrimonial das famílias de baixa renda, medida pela participação das despesas com aumento do ativo e redução do passivo, e um aumento no percentual das despesas correntes. Entre as duas pesquisas, embora tenham ocorrido aumentos nos percentuais de despesas com aquisição de imóveis (com exceção da faixa de rendimento de 2 a $3 \mathrm{SM}$, que praticamente ficou estável) e de veículos, houve redução ainda maior nos percentuais gastos com reforma de imóveis, levando os percentuais totais de crescimento patrimonial das famílias a diminuir, como pode ser visto no gráfico a seguir. 
FIGURA 14 : GRÁFICO DO PERCENTUAL DE RENDIMENTO DERIVADO PARA O CRESCIMENTO PATRIMONIAL

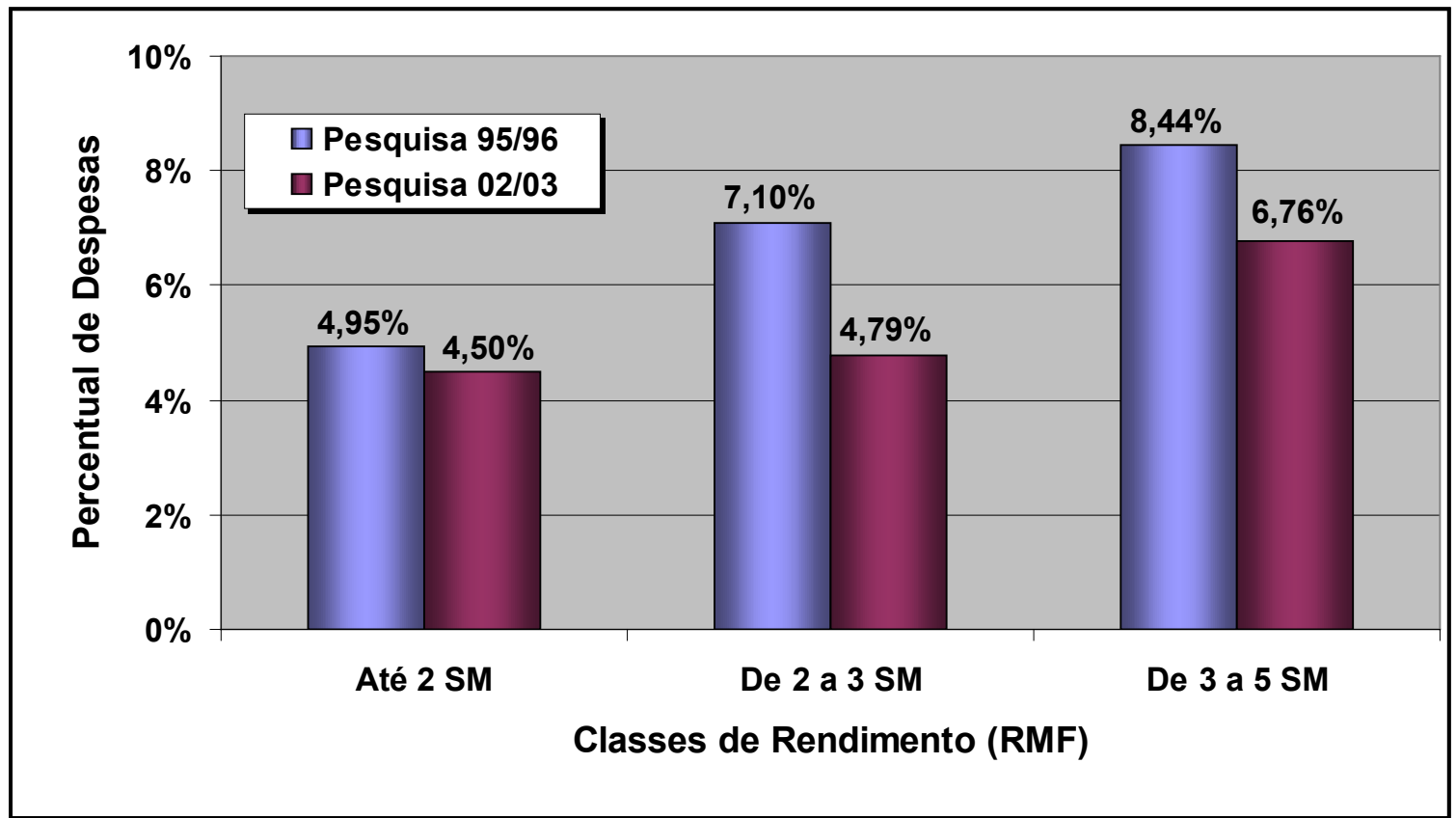

Fonte: Adaptado de IBGE, Pesquisas de Orçamentos Familiares, 2002/2003 e 1995/1996.

\subsubsection{A capacidade da população de baixa renda de pagar o preço da habitação}

Segundo o World Bank (2002), as famílias que ganham até 5 SM no Brasil estão em sua maioria excluídas do mercado formal de habitações, por não poderem pagar o preço da menor habitação popular, migrando, muitas vezes, para moradias subnormais.

Embora o salário mínimo ${ }^{23}$ tenha tido ganhos reais em relação à inflação dos últimos anos, medida pelo INCC e INPC, como demonstrado no item 3.6.2., a capacidade de pagar o preço para aquisição de uma habitação adequada ainda é limitada para a população de baixa renda. No gráfico que segue, pode-se ver as taxas de juros suportadas pela população de baixa renda, no pagamento de um financiamento habitacional para aquisição da habitação popular referência $(\mathrm{HPR})^{24}$, com preço de $\mathrm{R} \$ 25.260,00^{25}$, representando a menor habitação popular no mercado formal, sem levar em conta qualquer outra taxa e/ou remuneração agregadas à

\footnotetext{
${ }^{23}$ O salário mínimo considerado neste trabalho será de $\mathrm{R} \$ 350,00$, valor base Maio/2006.

${ }^{24}$ As características principais da unidade e o cálculo do preço da HPR estão descritos no item 5.1.2.

${ }^{25}$ Valor base Maio/2006.
} 
prestação e prevendo-se um comprometimento máximo de renda de $20 \%{ }^{26}$ da renda média mensal bruta das famílias de baixa renda. O prazo considerado para amortização dos financiamentos será um intervalo entre 6 e 20 anos, que representa, aproximadamente, o que está sendo praticado atualmente no mercado habitacional para a população de média e de baixa renda no Brasil. Não foram consideradas perdas inflacionárias entre o rendimento do comprador da unidade habitacional e o valor das prestações que este pagará à instituição financiadora, ou, caso estas perdas inflacionárias ocorram, serão absorvidas pela instituição financiadora e não pelo comprador.

FIGURA 15 : GRÁFICO DOS JUROS MÁXIMOS SUPORTADOS PARA O FINANCIAMENTO HABITACIONAL NA AQUISIÇÃO DA HABITAÇÃO POPULAR REFERÊNCIA, POR FAIXA DE RENDA

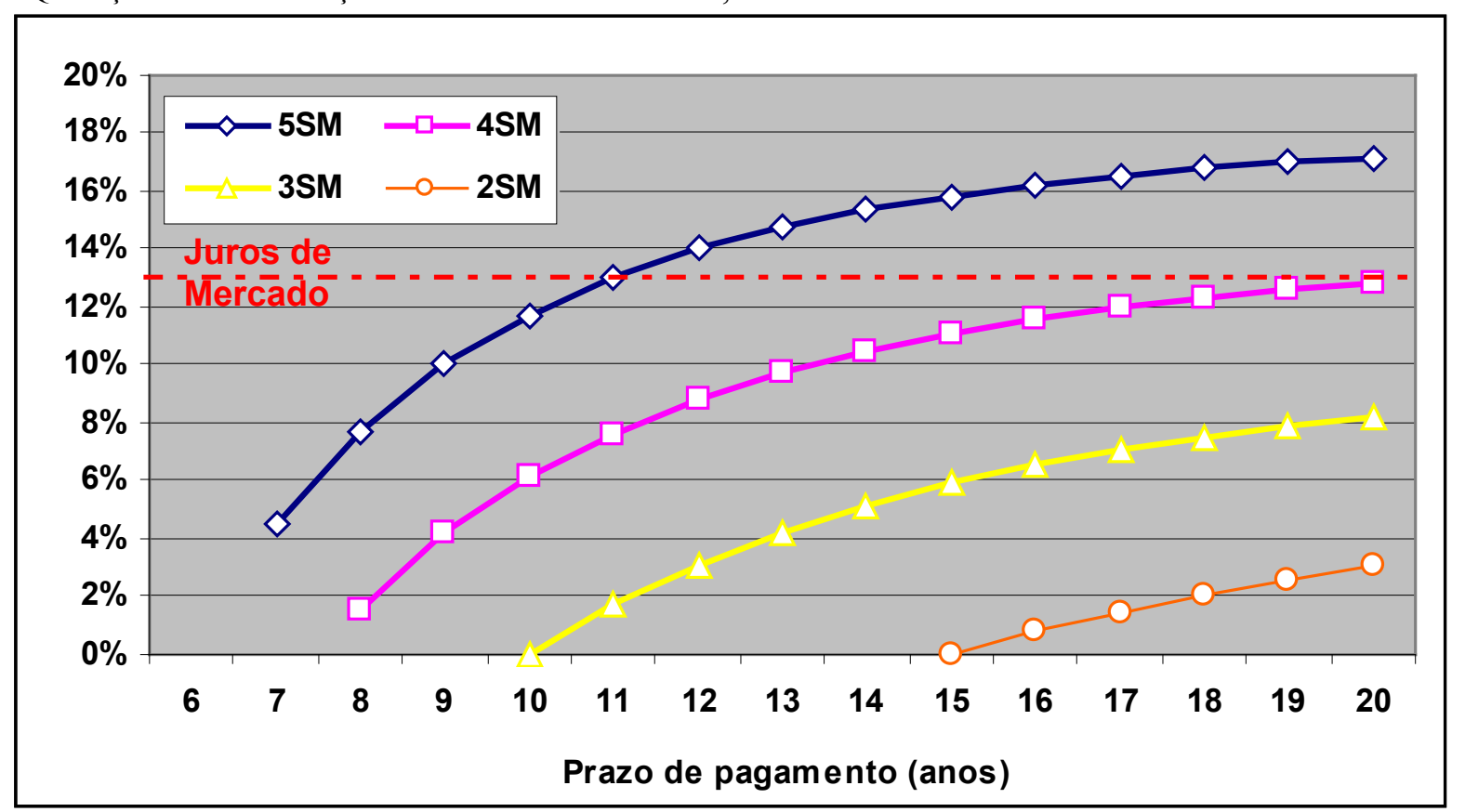

Para as famílias com renda mensal de 1SM, a parcela de qualquer financiamento habitacional, mesmo sem juros ${ }^{27}$, implicaria em um comprometimento de renda acima de $20 \%$ do orçamento familiar para a aquisição da HPR. As faixas de renda de 2SM, 3SM e 4SM conseguiriam adquirir a HPR com taxas de juros máximas, para amortização em 20 anos, de até 3\% a.a., 8,2\% a.a. e 12,8\% a.a., respectivamente, que teriam de ser subsidiadas, pois estão abaixo dos juros de mercado, considerado aqui como $13 \%{ }^{28}$ a.a.. Somente as famílias com

${ }^{26}$ O percentual de $20 \%$ é aproximadamente o que, em média, tem sido destinado pela população de baixa renda a despesas com habitação no orçamento familiar, como apresentado no item 3.5.

${ }^{27} \mathrm{O}$ financiamento sem juros representa os financiamentos com recursos não onerosos ofertados pelo Governo Federal para a população de baixa renda, como para os Programas PAR e Crédito Solidário.

${ }^{28}$ A taxa de juros de $13 \%$ a.a. representa os juros de mercado cobrados nas carteiras hipotecárias dos bancos de varejo [para o cálculo foi considerada a média aritmética das taxas de juros cobradas pelo Banco Real (disponível em: <www.bancoreal.com.br>, acesso em: 10 fev. 2007), Banco Itaú 
renda mensal de 5SM conseguiriam adquirir a HPR a juros de mercado, para amortização a partir de 14 anos.

Os resultados desta análise variarão com a variação do preço da habitação em relação à HPR aqui considerada, pois habitações normalmente têm preços diferentes para as diversas regiões brasileiras, resultado de variados preços locais de mão-de-obra e de materiais de construção, e também de diversificadas técnicas construtivas utilizadas.

(disponível em <www.itau.com.br>, acesso em 10 fev. 2007) e Banco HSBC (disponível em $<$ www.hsbc.com.br>, acesso em 10 fev. 2007) para financiamentos imobiliários fora do âmbito do $\mathrm{SFH}]$. 


\section{PROGRAMAS DE FINANCIAMENTO HABITACIONAL VOLTADOS À POPULAÇÃO DE BAIXA RENDA NO BRASIL}

O objetivo deste Capítulo é descrever o histórico dos programas de financiamento habitacional voltados à população de baixa renda no Brasil, desde a criação do Sistema Financeiro de Habitação, em 1964, até os programas de financiamento atualmente ofertados, destacando suas estruturas, fontes de recursos e resultados, juntamente com a apresentação dos aspectos da atual Política Nacional de Habitação do Governo Federal voltados ao financiamento habitacional da população de baixa renda, reconhecendo-se ao final o volume de recursos atualmente ofertados para o financiamento habitacional da população de baixa renda.

\subsection{Limitação da pesquisa}

A grande diversidade e quantidade de programas municipais e estaduais voltados à habitação existentes no Brasil, que funcionam de maneira particular e independente em cada localidade, e que vão desde o financiamento até a doação de unidades habitacionais para a população de baixa renda, dificultam seu estudo em razão da grande amplitude que a pesquisa teria de tomar para abranger todos os programas habitacionais regionais voltados ao financiamento da população de baixa renda, principalmente na busca de informações de desempenho que, na maioria das vezes, não são divulgadas propriamente. Assim, resolveu-se restringir a pesquisa aos programas de financiamento habitacional federais, que são os de maior amplitude no País, e que mostram os resultados mais significativos. Para ilustrar a maior amplitude dos programas de financiamento federais, e tomando-se como referência o Estado de São Paulo, que tem o maior programa habitacional estadual no Brasil, por meio da CDHU - Companhia de Desenvolvimento Habitacional e Urbano, e que, segundo SINDUSCON/SP; FGV (2006), entregou em 2005 aproximadamente 21 mil unidades habitacionais, o que corresponde aproximadamente a $6 \%$ do número de habitações financiadas pelo Governo Federal no mesmo ano, para a população de baixa renda. 


\subsection{Histórico dos programas de financiamento habitacional no Brasil}

\subsubsection{Auge e declínio do Sistema Financeiro de Habitação - SFH $(1964 / 1985)$}

\subsubsection{Criação e estruturação do SFH}

A partir da década de 1930, o Governo brasileiro começou a ter uma intervenção mais marcante na área habitacional. Foram criados os institutos de aposentadoria e pensões e a Fundação da Casa Popular. A atenção voltou-se então para a casa própria, em parte em decorrência da lei do inquilinato de 1942, que congelou os aluguéis até 1964, juntamente com o início dos programas de erradicação de favelas a partir da década de 1940. Estas intervenções governamentais, entretanto, foram somente pontuais, pouco contribuindo para evitar os problemas urbanos. Diferentemente do que acontecia nos países do Primeiro Mundo, o crescimento populacional no Brasil foi excessivamente rápido, não se fazendo acompanhar por uma urbanização adequada das cidades. Entre 1940 e 1960, a população brasileira passou de 41 milhões para 70 milhões de habitantes, com a taxa de urbanização aumentando de $31 \%$ para $45 \%$. Isto provocou um aumento dos assentamentos irregulares, consolidando-se a busca das periferias das cidades como local de moradia pela população de baixa renda (CAIXA ECONÔMICA FEDERAL, 2002b).

Era grave a situação do setor habitacional brasileiro no período imediatamente anterior à criação do SFH. O rápido crescimento da demanda por habitações urbanas, dentro de um contexto inibidor do investimento na área habitacional (marcado por um forte vetor inflacionário, taxas de juros nominais fixas e leis populistas no mercado de alugueis), colaborou com o rápido crescimento do déficit habitacional no Brasil (KAMPEL; VALLE, 1974).

Sobre a criação do SFH, Kampel;Valle (1974, p.13) entendem que,

Com o objetivo de corrigir essas distorções, o governo procurou estabelecer as condições de funcionamento de um mercado financeiro habitacional capaz de operar em bases economicamente realistas, tendo como suporte a institucionalização da correção monetária nos financiamentos imobiliários e a criação, dentro do Sistema Financeiro Habitacional, de um setor 
especializado em crédito imobiliário, composto pelo Banco Nacional de Habitação, Sociedades de Crédito Imobiliário, Cooperativas, Fundações, Associações de Poupança e Empréstimo e Caixas Econômicas. O novo sistema foi montado através da Lei no. 4.380, de 21 de agosto de 1964.

A criação do Sistema Financeiro Habitacional visava aproximar a oferta às necessidades de habitação a um menor custo. Nesse sentido foram criados programas e financiamentos especificos para as diferentes classes sociais. Objetivou-se também o estímulo à industria de construção e de utilidades domésticas fato que iria acarretar uma maior absorção de largos contingentes de mão-de-obra não especializada e ligada direta ou indiretamente ao setor.

As fontes de recursos eram basicamente duas: a arrecadação do Sistema Brasileiro de Poupança e Empréstimos (SBPE), compreendendo o conjunto de captações das letras imobiliárias e cadernetas de poupança; e, a partir de 1967, o Fundo de Garantia do Tempo de Serviço (FGTS), proveniente de contribuições compulsórias dos empregadores em nome dos empregados do setor formal da economia. O órgão central do SFH era o BNH, responsável pelo gerenciamento do FGTS, pela normalização e fiscalização da aplicação dos recursos das cadernetas de poupança e pela definição das condições de financiamento das habitações para a população (SANTOS, 1999).

Segundo Santos (1999), para entender o financiamento do SFH, é conveniente dividi-lo em dois subsistemas, o SBPE e o BNH-FGTS. O primeiro subsistema captava os recursos das cadernetas de poupança e dos demais títulos imobiliários por meio de associações de poupança e empréstimo, que serviam para financiar investimentos habitacionais propostos por empreendedores e/ou construtoras. Depois de recebido o financiamento, os empreendedores e/ou construtoras responsabilizavam-se pela construção e venda das unidades habitacionais, basicamente para as classes de renda média e alta, e estes, por sua vez, responsabilizavam-se pelo pagamento do financiamento diretamente às instituições financeiras, tornando-se mutuários do sistema; o segundo subsistema captava recursos do FGTS, destinando os recursos "prioritariamente à construção de casas de interesse social (conjuntos populares e cooperativas)" (SANTOS, 1999 apud AZEVEDO,1995, p. 293) ${ }^{29}$. As COHABs ${ }^{30}$, companhias de habitação, eram as principais ${ }^{31}$ responsáveis pela construção das unidades habitacionais, que associavam "a execução de programas setoriais de construção de

${ }^{29}$ AZEVEDO, S. O desempenho do poder público na área habitacional: um breve retrospecto. In: Déficit Habitacional no Brasil. Belo Horizonte: Fundação João Pinheiro, 1995.

${ }^{30}$ Empresas mistas sob o controle acionário dos governos estaduais e/ou municipais. 
habitações às atividades financeiras referentes à comercialização". (KAMPEL;VALLE 1974, p.14). As COHABs, então, obtinham os financiamentos do BNH-FGTS mediante a apresentação de projetos que fossem tecnicamente compatíveis com as diretrizes do Banco, supervisionavam a construção e faziam a comercialização das unidades habitacionais, a preço de custo, para as camadas mais pobres da população, que se incumbiam de pagar os financiamentos para as COHABs.

Pela estruturação do SFH, verifica-se que basicamente havia dois itens principais responsáveis pelo seu desempenho: a capacidade de arrecadação de recursos do FGTS e do SBPE e o retorno de suas próprias aplicações, influenciado fortemente pela inadimplência dos mutuários. A arrecadação do FGTS dependia dos índices de emprego formal e do salário médio, enquanto a arrecadação do SBPE dependia da renda e da taxa de juros real oferecida aos investidores.

\subsubsection{O funcionamento do SFH no período 1964/1985}

De acordo com Vasconcelos; Cândido Júnior (1996, p.16),

o SFH atingiu o seu auge no final da década de 70 e início da década de 80, quando se conseguiu o financiamento de 400 mil novas unidades por ano. No entanto, o sistema enfrentou um problema crônico: o descompasso entre os reajustes salariais e os das prestações. A interferência do governo para resolver este problema não foi eficiente, levando ao declínio do SFH, [...]. A solução foi implementada por meio do Plano de Equivalência Salarial (PES), que determinava que as prestações fossem reajustadas anualmente na proporção do aumento do salário-mínimo, enquanto os saldos devedores variavam trimestralmente. Portanto o prazo de amortização se elevava, ajustando o descompasso. Para cobrir o aumento de prazos, foi criado o Fundo de Compensação de Variação Salariais (FCVS), que quitaria a dívida restante do mutuário do PES, quando o prazo excedia $50 \%$ do contrato de inicio. O FCVS deveria ser financiado por uma sobretaxa incidente sobre as prestações dos mutuários.

Esta solução, em tempos de inflação moderada, manteve o descompasso do reajuste das prestações em relação aos saldos devedores dos financiamentos habitacionais em patamares controláveis. Segundo Ferreira (2004, p.34),

\footnotetext{
${ }^{31}$ Eram agentes promotores do sistema também, além das COHABs, cooperativas habitacionais
} (COOPHABs) e outras entidades públicas e privadas atuantes no setor (KAMPEL;VALLE, 1974). 
[...] o SFH ainda não apresentava graves problemas. De fato, o sistema apresentava um bom funcionamento: os planos de reajustes das prestações eram gerenciados de maneira satisfatória, sem fortes compromissos potenciais do FCVS, apesar de alguns planos de financiamento apresentarem uma inconsistência financeira intrínseca à sua estrutura.

Em 1979, com a segunda crise do petróleo e as mudanças nos mercados financeiros internacionais, a estratégia brasileira de crescimento com endividamento mostrou-se frágil. Ficou claro que o crescimento só fora possível em razão da grande disponibilidade de recursos externos e ao uso da poupança pública. A escassez desses recursos, aliada à queda dos preços dos produtos de exportação brasileiros e ao salto observado nas taxas de inflação, levou o Governo brasileiro a adotar uma drástica política de ajustamento interno, que acarretou queda forte do PIB. Embora essas políticas contracionistas tenham sido bemsucedidas no que diz respeito à geração de superavits comerciais e ao reequilíbrio do balanço de pagamentos, elas não tiveram êxito na contenção do processo inflacionário (FERREIRA, 2004).

Na década de 1980, os desequilíbrios do FCVS atingiram grandes proporções em decorrência da aceleração inflacionária, pois a inflação chegou ao patamar de $200 \%$ ao ano em 1983. Segundo Ferreira (2004), a elevação das taxas de desemprego, a redução do salário real e o aumento inflacionário acarretaram sérios problemas ao $\mathrm{SFH}$, ao prejudicarem suas principais fontes de entrada de recursos, ou seja, as cadernetas de poupança, o FGTS e o retorno dos financiamentos concedidos.

Embora um dos principais objetivos do SFH fosse atender principalmente à população de baixa renda, isto não se consolidou na prática, pois a maioria dos recursos para financiamento do SFH foi dirigida ao financiamento habitacional das classes de renda mais elevada. Santos $(1999$, p.17) constata que

[...] o sistema foi incapaz de atender à população de baixa renda. Com efeito, somente 33,5\% das unidades habitacionais financiadas pelo SFH ao longo da existência do BNH foram destinadas à habitação de interesse social e, dado que o valor médio dos financiamentos de interesse social é inferior ao valor médio dos financiamentos para as classes de renda mais elevada, é lícito supor que uma parcela ainda menor do valor total dos financiamentos foi direcionada para os primeiros. 


\subsubsection{A Nova República}

Em decorrência de uma grande pressão da opinião pública, exercida principalmente pelos mutuários, e a um grande aumento da inadimplência no sistema, em 1985 foi dado um subsídio significativo para seus mutuários. O reajuste das prestações no âmbito do PES, enquanto que se reajustado com base no salário mínimo seria de $243 \%$ e se reajustado pela $\mathrm{UPC}^{32}$ seria de $246 \%$, acabou sendo de $112 \%{ }^{33}$. Isto se o mutuário optasse por correções semestrais e estivesse adimplente (para se tornar adimplente, bastava incorporar ao saldo devedor os encargos eventualmente em atraso), o que foi a opção da maioria.

O subsídio ofertado contribuiu com a diminuição da inadimplência, mas aumentou consideravelmente o descasamento entre a evolução do passivo junto aos poupadores do SBPE e FGTS e o ativo (as prestações dos mutuários) do SFH. Contribuindo substancialmente com o déficit do FCVS. Cabe ressaltar que este subsídio foi dado a todos os mutuários do sistema que optaram por ele, sem separação dos mutuários por classes de renda, tendo estes subsídios então beneficiado, em sua maioria, as famílias de renda média e alta (SANTOS, 1999).

Em 1986 o SFH sofreu mais um impacto com o lançamento do Plano Cruzado. De acordo com o plano as prestações seriam convertidas pelo valor médio das 3, 6, 9 e 12 prestações imediatamente anteriores a março de 1986, dependendo da data do último reajustamento, e permaneceriam congeladas por 12 meses. Como a correção monetária continuou a reajustar o passivo do sistema (poupança e FGTS), esta medida causou mais um aumento no déficit do FCVS. Segundo $\operatorname{Simosen}^{34}$ (1991, apud SANTOS, 1999, p.14):

\footnotetext{
32 UPC: Unidade Padrão de Capital equivalente ao valor nominal das Obrigações Reajustáveis do Tesouro Nacional. Segundo Triana (2006, p.73), a UPC, criada em 1966, era "uma espécie de moeda estável que serviria como balizador para as operações do SFH: todas as referências à moeda corrente daquela época - o cruzeiro - eram também representadas em UPC, tais como o valor do financiamento, o valor do imóvel, a renda dos devedores e as respectivas prestações, etc. A variação da UPC correspondia, em síntese, à desvalorização da moeda e determinava, portanto, o percentual de correção monetária a ser aplicado aos financiamentos".

${ }^{33} \mathrm{O}$ subsídio dado no reajuste das prestações teve grande motivação política, e não técnica, após uma grande pressão popular, tendo criado conseqüências desastrosas para o sistema.

${ }^{34}$ SIMONSEN, M.H. Poupança e crescimento: o caso brasileiro. Ensaios Econômicos, EPGE, n.78, 1991.
} 
Com os subsídios aos mutuários concedidos em 1985, e com o plano Cruzado[...], lançou-se no FCVS um rombo que ninguém conhece ao certo, mas que é estimado na faixa de 20 a 30 bilhões de dólares. O resultado de toda essa pseudo-generosidade é bem conhecido. Os mutuários de SFH pagam prestações irrisórias, na faixa de 5\% a $10 \%$ dos aluguéis correspondentes. Como resultado, essas prestações nem cobrem os juros dos saldos devedores existentes. Isso significa que o sistema não consegue retorno de caixa que lhe permita conceder novos financiamentos em volume expressivo.

Diante deste quadro de deficiência do $\mathrm{SFH}$, se tornou evidente a necessidade de uma profunda reformulação no sistema, o que aconteceu em 1986, com a extinção do BNH e a pulverização de suas funções distribuídas entre o Conselho Monetário Nacional, o Banco Central, o Ministério de Desenvolvimento Urbano e a Caixa Econômica Federal. Segundo Ferreira (2004), após a extinção do BNH, iniciou-se uma crise institucional, pela pouca experiência no setor habitacional das instituições que assumiram as funções do BNH.

Oliveira (2000, p.49) constata que

[...] o balanço do BNH ao longo dos seus 22 anos de existência deixa claro o alijamento das camadas de baixa renda, em especial as famílias com renda inferior a três salários mínimos. Parcela majoritária da população, essas famílias vêm buscando a solução para o problema da moradia através dos mecanismos de autoconstrução, habitando cortiços, casas precariamente construidas nas favelas e periferias distantes, e convivendo com expressiva carência de bens de consumo coletivo. Dados da Pesquisa Nacional por Amostra de Domicílio - PNAD apontam para o acentuado crescimento de domicílios de construção rústica no período de existências do BNH.

Nos seus 22 anos de existência, o BNH financiou aproximadamente 4,5 milhões de moradias no Brasil, aproximadamente $27,66 \%$ das moradias construídas no período no País, distribuídas da seguinte forma: 
TABELA 4 : NÚMERO DE FINANCIAMENTOS HABITACIONAIS CONCEDIDOS PELO SISTEMA FINANCEIRO DA HABITAÇÃO NO PERÍODO DE 1964 A 1986, EM MILHARES DE MORADIAS.

\begin{tabular}{|c|c|c|c|c|c|c|c|c|c|}
\hline \multicolumn{3}{|c|}{ Mercado Popular ${ }^{(1)}$} & \multicolumn{3}{|c|}{ Mercado Econômico (2) } & \multicolumn{3}{|c|}{ Mercado Médio ${ }^{(3)}$} & \multirow{2}{*}{ 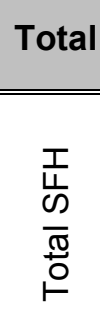 } \\
\hline 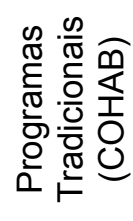 & 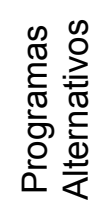 & $\begin{array}{l}\frac{0}{0} \\
\frac{0}{0} \\
\frac{0}{0} \\
\frac{\pi}{0} \\
\frac{\pi}{0} \\
\qquad \frac{0}{5}\end{array}$ & 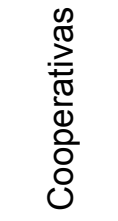 & 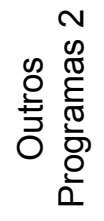 & $\begin{array}{l}00 \\
\frac{0}{0} \\
\frac{0}{\pi} \\
\frac{\pi}{\pi} \\
0 \\
\end{array}$ & $\begin{array}{l}m \\
\stackrel{m}{0} \\
\stackrel{\infty}{\infty}\end{array}$ & 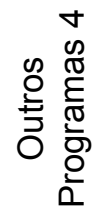 & 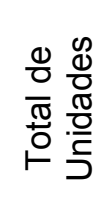 & \\
\hline $\begin{array}{c}1.235 \\
27,7 \%\end{array}$ & $\begin{array}{c}264 \\
5,9 \%\end{array}$ & $\begin{array}{c}1.499 \\
33,6 \%\end{array}$ & $\begin{array}{c}489 \\
10,9 \%\end{array}$ & $\begin{array}{c}299 \\
6,7 \%\end{array}$ & $\begin{array}{c}788 \\
17,6 \%\end{array}$ & $\begin{array}{r}1.899 \\
42,5 \%\end{array}$ & $\begin{array}{c}280 \\
6,3 \%\end{array}$ & $\begin{array}{c}2.179 \\
48,8 \%\end{array}$ & $\begin{array}{l}4.466 \\
100 \%\end{array}$ \\
\hline
\end{tabular}

Fonte: Azevedo (1988, apud OLIVEIRA, 2000).

(1) - Programas de financiamento ao mercado popular: visavam a atender as famílias de renda igual ou superior a um salário mínimo regional por mês. Os financiamentos deveriam ter valor unitário de até 200 UPC;

(2) - Programas de financiamento ao mercado econômico: visavam a atender as famílias com renda mensal mínima de 6,20 UPC, com financiamento de valor unitário entre 200 e 400 UPC;

(3) - Programas de financiamento ao mercado médio: visavam a atender as famílias com renda mensal mínima, a partir de 19,20 UPC, com financiamento de valor superior a 400 UPC. (KAMPEL;VALLE, 1974).

\subsubsection{O Período Pré - Plano Real}

A crise do setor habitacional aprofundou-se no período 1985/1989, entrando o setor em uma grande crise institucional com a extinção do BNH. Para Santos (1999), mesmo com pesados investimentos realizados em programas alternativos com foco na população de baixa renda, estes foram objeto de todo tipo de má utilização de recursos, contribuindo para enfraquecer as COHAB's; foram ações segmentadas sem uma política habitacional consistente.

Em 1990, toma posse o primeiro presidente eleito depois do regime militar. No setor habitacional, é criado o Plano de Ação Imediata para Habitação - PAIH, programa que apresentava metas ambiciosas, em caráter emergencial: a construção de 245 mil unidades em 180 dias, pela contratação de empreiteiras privadas, operado pela Caixa Econômica Federal; focava a população com renda até 5SM e utilizava recursos do FGTS. Oliveira (2000) expressa que as metas não foram atingidas, o que se conseguiu foi a construção de 210 mil unidades em período maior do que 18 meses. 
Com o impeachment do Presidente em 1992, houve mudanças significativas na gestão na área de habitação. Segundo Santos (1999, p.21),

[...] os programas na área de habitação popular, [...], foram redesenhados e passam a exigir a participação de conselhos com participação comunitária dos governos locais e uma contrapartida financeira desses últimos aos investimentos da União. Tais mudanças aumentaram significativamente o controle social e a gestão dos programas em questão [...].

Houve também grande preocupação em terminar obras inacabadas, contratadas na gestão anterior, com recursos do FGTS. Para estancar o déficit do FCVS, extingui-se o PES, substituindo-o pelo Plano de Comprometimento de Renda (PCR) ${ }^{35}$, um plano baseado no comprometimento da renda do mutuário e que visava a evitar as defasagens das prestações em relação à amortização dos financiamentos. Santos (1999) acentua ainda que tais mudanças não foram suficientes para reverter o quadro de crise estrutural do sistema.

\subsubsection{O Período Pós - Plano Real}

Em 1995, o Governo Federal recém-empossado reconhecia as necessidades habitacionais presentes no País. Com base em estudos do IBGE, admitia-se um déficit habitacional da ordem de 5,6 milhões de moradias, e um déficit qualitativo, com domicílios precários, com infra-estrutura inadequada e/ou com adensamento excessivo da ordem de 13 milhões de moradias. Deste déficit, $85 \%$ era representado por famílias com renda mensal de até 5SM. Verificou-se também que das 5,1 milhões de novas moradias incrementadas ao estoque de domicílios entre 1991 e 1996, em sua maioria, encontravam-se na faixa de renda superior a 20SM (OLIVEIRA, 2000).

O Governo Federal, entretanto, apontava também três aspectos importantes sobre o modelo de intervenção habitacional baseado no SFH que vinha sendo utilizado, que era: esgotamento do sistema, em razão da crescente dificuldade com a captação líquida de recursos (notadamente

\footnotetext{
${ }^{35}$ No PCR, as prestações mensais eram reajustadas tendo como base o mesmo índice e a mesma periodicidade de atualização do saldo devedor dos contratos, mas assegurava ao mutuário o direito de revisão das prestações mensais visando a adequar a relação entre a prestação mensal e a renda mensal bruta do mutuário ao percentual máximo de comprometimento de renda estabelecido no contrato (de no máximo de $30 \%$ ).
} 
do FGTS); o caráter regressivo dos subsídios implícitos, por beneficiar principalmente a população com renda média e alta; e sua insuficiência, porque durante 30 anos gerou somente 5,6 milhões de moradias, do total de 31,6 milhões de novas moradias produzidas.

Segundo Santos (1999, p.22), o Governo Federal propôs, então, um novo modelo habitacional com quatro premissas básicas:

(i) a focalização das políticas públicas voltadas para a área habitacional no atendimento das camadas populacionais de baixa renda, [...]; (ii) a necessidade de descentralizar e aumentar o controle social sobre a gestão dos programas federais de habitação; (iii) o reconhecimento, por parte do governo, de sua incapacidade de resolver sozinho o problema habitacional do país e da necessidade de tentar melhorar o funcionamento do mercado de moradias no Brasil; e (iv) o reconhecimento de que as políticas públicas não devem negligenciar a grande parcela da população de baixa renda que trabalha no setor informal da economia elou habita moradias informais.

O Governo Federal, então, mudou a sua posição quanto ao setor habitacional, visando a focarse na população de baixa e média renda. Além disso, as políticas deveriam buscar utilizar mecanismos de mercado, como o Programa Carta de Crédito - FGTS/SBPE. As intervenções diretas do Governo se restringiriam à provisão/melhorias de áreas altamente degradadas, com pobreza extrema, como os Programas Pró-moradia ${ }^{36}$ e Habitar-Brasil. As necessidades habitacionais da população de renda média e alta são deixadas a cargo do mercado, mediante a criação do Sistema de Financiamento Imobiliário (SFI) e do Programa Carta de Crédito SBPE.

A criação do programa Carta de Crédito introduz o conceito de crédito direto ao consumidor final, que tem liberdade de escolha do imóvel, como também outras opções que não somente a compra da unidade habitacional nova, como para a compra de terreno, materiais de construção e imóveis usados.

\footnotetext{
${ }^{36}$ O programa Pró-moradia é financiado pelo FGTS, recursos onerosos que são tomados por estados e municípios para melhoria de áreas degradadas (por serem recursos onerosos, são feitas exigências financeiras quanto à capacidade de pagamento para aprovação desses financiamentos junto a estados e municípios, que muitos não conseguem atender). O programa Habitar-Brasil utiliza recursos do Orçamento Geral da União, portanto não onerosos e a fundo perdido, também para a recuperação de áreas degradadas. Juntos, entre 1995 e 1998, foram feitos investimentos da ordem de R \$ 2,16 bilhões, que beneficiaram aproximadamente 722 mil famílias (SANTOS, 1999).
} 


\subsection{As principais fontes de recursos dos programas de financiamento habitacional no Brasil - FGTS E SBPE}

\subsubsection{O FGTS - Fundo de Garantia do Tempo de Serviço}

No Brasil, o FGTS é a fonte com o maior volume de recursos onerosos ${ }^{37}$ voltados ao financiamento habitacional da população de baixa renda (ALVES, 2006).

Segundo Carvalho; Pinheiro (2000, p.51),

o FGTS é um fundo contábil de natureza financeira, constituido pelo conjunto de contas vinculadas e individuais, abertas pelos empregadores em nome de seus empregados. Foi criado pela Lei 5.107, de 13 de setembro de 1966, substituindo na prática o regime de indenização por rescisão de contrato de trabalho então vigente.[...]. A criação do FGTS respondeu a um triplo objetivo:

a) seguro social: o fundo objetiva a criação de pecúlio para o trabalhador, que lhe servisse no periodo de inatividade permanente e que também funcionasse como indenização por dispensa do emprego sem justa causa e como seguro-desemprego; ou seja, o FGTS foi criado para ser, antes de tudo, patrimônio do trabalhador;

b) eficiência alocativa do mercado de trabalho: a criação do fundo procurava facilitar a demissão dos trabalhadores pelas empresas, instituindo o provisionamento compulsório da indenização e acabando com a estabilidade aos dez anos de serviço [...];

c) financiamento da habitação: os recursos do fundo seriam incorporados ao Sistema Financeiro da Habitação (SFH) e, ao cargo do Banco Nacional da Habitação (BNH), financiariam a construção de habitações.

A Lei 8.036/1990 estabelece que "o FGTS será regido por normas e diretrizes estabelecidas por um Conselho Curador, composto por representes de trabalhadores, empregadores e órgãos e entidades governamentais, na forma estabelecida pelo poder Executivo." Cabe à Caixa Econômica Federal o papel de agente operador do FGTS, sendo esta responsável por centralizar os recursos, manter e controlar as contas vinculadas, participar da rede arrecadadora dos recursos, expedir atos normativos referentes aos procedimentos administrativo-operacionais de todos os agentes participantes integrados ao sistema do FGTS,

\footnotetext{
${ }^{37}$ Recursos onerosos são aqueles recursos utilizados nos financiamentos sobre os quais, além da correção monetária, são cobrados juros, como retorno do financiamento.
} 
definir os procedimentos operacionais necessários à execução dos programas de habitação popular, saneamento básico e infra-estrutura urbana estabelecidos pelo Conselho Curador com base nas normas e diretrizes de aplicação elaboradas pelo poder Executivo, dentre outras atribuições.

Ainda segundo a Lei 8.036/1990, compete ao Conselho Curador do FGTS (CCFGTS) estabelecer as diretrizes e os programas de alocação de recursos do FGTS, de acordo com os critérios dessa lei, da política nacional de desenvolvimento urbano e das políticas setoriais de habitação popular; acompanhar e avaliar a gestão econômica e financeira dos recursos, bem como ganhos sociais e o desempenho dos programas aprovados; apreciar e aprovar os programas anuais e plurianuais do FGTS; dirimir dúvidas quanto à aplicação de normas regulamentares; fixar normas e valores para remuneração do agente operador e dos agentes financeiros - dentre outras atribuições.

Segundo a Resolução 460/2004 do Conselho Curador do Fundo de Garantia do Tempo de Serviço, o FGTS tem como fluxo de entrada de recursos, no mínimo, os seguintes itens:

- depósitos efetuados pelo empregador nas contas vinculadas; retorno das operações de crédito; multas, correção monetária e juros moratórios; receitas financeiras líquidas; arrecadação de contribuição social; créditos securitizados FCVS (Fundo de Compensação de Variações Salariais); operações compromissadas; e outras receitas.

E como fluxo de saída de recursos, no mínimo, os seguintes itens:

- $\quad$ saques de contas vinculadas; desembolso das operações de crédito; encargos autorizados pelo Conselho Curador; pagamento de créditos complementares; e resgate de operações compromissadas.

Os depósitos efetuados pelas empresas nas contas vinculadas dos empregados, porém, são a principal fonte de recursos do FGTS. Estes depósitos são feitos no valor equivalente a $8 \%$ das remunerações pagas ou devidas aos empregados, são de natureza social e têm caráter compulsório, sendo as contas vinculadas dos empregados impenhoráveis. Tem direito ao FGTS os trabalhadores urbanos e rurais. A Lei 10.208/2001 facultou a inclusão do empregado 
doméstico no sistema do FGTS, de acordo com a vontade do empregador (CAIXA ECONÔMICA FEDERAL, 2006a).

A Lei 8.036/1990, em seu artigo nono, revisada pela Lei $9.467 / 1997$, determina que as aplicações com recursos do FGTS poderão ser realizadas diretamente pela Caixa Econômica Federal e pelos demais integrantes do Sistema Financeiro da Habitação - SFH, exclusivamente segundo critérios fixados pelo Conselho Curador do FGTS, em operações que preencham alguns requisitos, como garantias (hipotecas, alienação fiduciária, garantias reais, etc.), correção monetária igual à das contas vinculadas e taxa de juros mínima de 3\% ao ano por projeto. É determinado, ainda, que a rentabilidade média das aplicações deverá ser suficiente para cobrir todos os custos incorridos e ainda formar uma reserva técnica para o atendimento de gastos eventuais imprevistos, sendo da Caixa Econômica Federal o risco de crédito; e que o programa de aplicações deve destinar, no mínimo, $60 \%$ dos investimentos para habitação popular.

As aplicações dos recursos do FGTS, de acordo com a Resolução 460/2004 do CCFGTS, adotarão as seguintes definições:

- $\quad$ empréstimo - operação de crédito entre o agente operador e o agente financeiro;

- financiamento - operação de crédito entre o agente financeiro e o mutuário, com recursos originários da operação de empréstimo;

- $\quad$ agentes financeiros - os agentes financeiros do Sistema Financeiro de Habitação - SFH; e

- $\quad$ mutuários - pessoas físicas ou jurídicas definidas pelos programas de aplicação do FGTS.

O modelo a seguir demonstra o fluxo de recursos do FGTS e a atuação de cada agente. 


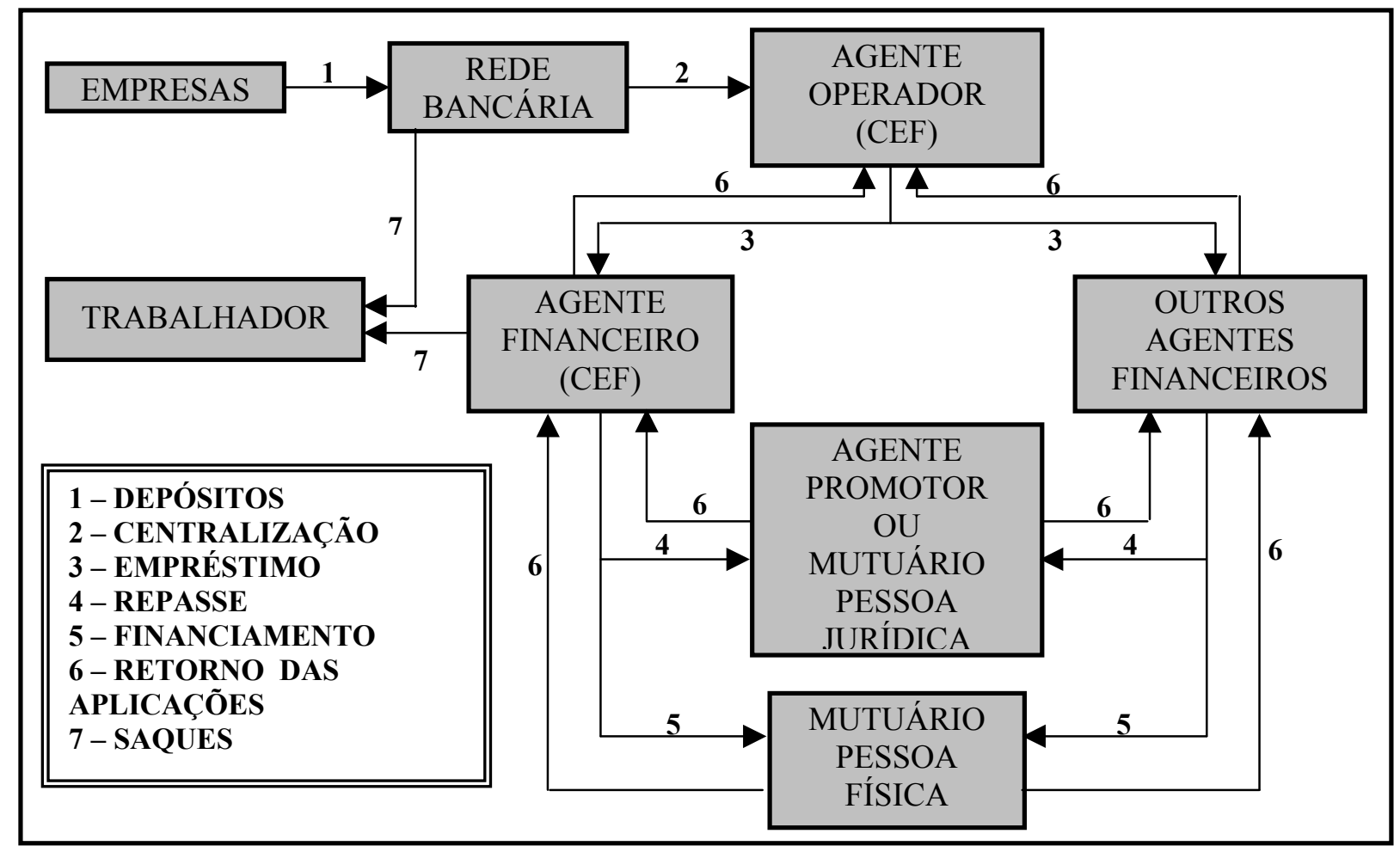

Fonte: Carvalho; Pinheiro (2000).

O primeiro fluxo corresponde aos depósitos feitos pelos empregadores em contas vinculadas em nome dos empregados; no segundo fluxo, os recursos dispersos na rede bancária são centralizados e geridos pela Caixa Econômica Federal; no terceiro fluxo, acontecem os empréstimos entre o agente operador (CEF) e os agentes financeiros (a Caixa Econômica Federal, por ser um banco de varejo, além de ser o agente operador também é um dos agentes financeiros); o quarto fluxo ocorre quando os agentes financeiros repassam os recursos aos agentes promotores e aos mutuários pessoa jurídica $(\mathrm{COHAB}$, incorporadoras e outras entidades que se encarregam de promover a construção de unidades habitacionais e financiálas às pessoas físicas); o quinto fluxo é intitulado financiamento, cujos recursos finalmente são transferidos aos mutuários finais; o sexto fluxo trata do retorno dos recursos acrescidos de juros e outros encargos financeiros aplicáveis; e o sétimo fluxo representa os saques e as retiradas, pelos empregados, dos recursos da sua conta vinculada, que podem ser retirados em condições específicas determinadas pela legislação pertinente (CARVALHO; PINHEIRO, 2000.) 
A Resolução 460/2004 do CCFGTS, em seu artigo terceiro, determina o público-alvo, ou seja, os tomadores de financiamentos habitacionais com recursos do FGTS. Este público-alvo é dividido em duas áreas : a de Habitação Popular e a de Habitação/Operações Especiais. As operações de financiamento na área de Habitação Popular atendem à população com renda familiar bruta até R\$ 3.900,00 e na área de Habitação/Operações Especiais atendem à população com renda familiar bruta até $\mathrm{R} \$ 4.900,00$. Esta mesma Lei determina que, para a área de Habitação Popular o limite será reduzido gradualmente até R \$2.600,00 no exercício de 2008 e que, para a área de Habitação/Operações Especiais, o limite será gradualmente reduzido até sua extinção a partir do exercício de 2008, ou seja, os recursos do FGTS ficarão cada vez mais direcionados à população de baixa renda. É determinado também que a forma de redução dos limites citados será feita pelo CCFGTS, por proposição do gestor de aplicação, que levará em consideração as condições de crédito disponíveis no mercado imobiliário e o perfil do déficit habitacional.

Para a tomada de financiamentos, a Resolução 460/2004 do CCFGTS demanda que os mutuários pessoas físicas não podem deter, em qualquer parte do País, outro financiamento nas condições do SFH e que não podem ser proprietários, promitentes compradores ou titulares de direito de aquisição de imóvel residencial no atual local de domicílio nem onde pretendem fixá-lo. É determinado nesta resolução e complementado pela Resolução 482/2005 que os imóveis objeto do financiamento com recursos do FGTS, nas áreas de Habitação Popular e Habitação/Operações Especiais, observarão os limites máximos descritos a seguir.

TABELA 5: LIMITES PARA FINANCIAMENTOS HABITACIONAIS COM RECURSOS DO FGTS.

\begin{tabular}{c|c|c}
\hline \multirow{2}{*}{ Áreas } & \multicolumn{2}{|c}{ VV/VA ou VI } \\
\cline { 2 - 3 } & $\begin{array}{c}\text { São Paulo } \\
\text { Rio de Janeiro } \\
\text { Distrito Federal }\end{array}$ & Demais regiões do País \\
\hline Habitação Popular & $\mathrm{R} \$ 80.000,00$ & $\mathrm{R} \$ 72.000,00$ \\
\hline Habitação/Operações Especiais & $\begin{array}{c}\text { De } \mathrm{R} \$ 80.000,01 \\
\text { a } \mathrm{R} \$ 100.000,00\end{array}$ & $\begin{array}{c}\mathrm{De} \mathrm{R} \$ 72.000,01 \\
\text { a } \mathrm{R} \$ 80.000,00\end{array}$ \\
\hline \hline
\end{tabular}

Fonte: Resoluções do CCFGTS 460/2004 e 482/2005.

Reais correntes.

(1) VV, VA e VI representam, respectivamente, os valores de venda, de avaliação e de investimento. Os valores de venda e avaliação deverão ser comparados entre si, optando-se pelo maior para enquadramento do imóvel. O valor-limite do investimento, nos casos de conclusão, ampliação, reforma ou melhoria, englobará o valor do imóvel no estado atual acrescido do valor das benfeitorias a serem financiadas (RESOLUÇÃO 460/2004). 
Nas áreas de Habitação Popular e Habitação/Operações Especiais, é estipulado pela Resolução 460/2004 do CCFGTS, dentre outras coisas, que:

- os tomadores de financiamentos habitacionais com recursos do FGTS deverão dar uma contrapartida mínima de 5\% sobre os valores de venda, avaliação ou investimento para pessoas físicas, setor público e pessoas jurídicas sem fins lucrativos, e 10\% para as demais pessoas jurídicas;

- o prazo máximo para amortização dos financiamentos habitacionais é de 30 anos para pessoas físicas, 20 anos para pessoas jurídicas sem fins lucrativos e 15 anos para as demais pessoas jurídicas;

- $\quad$ as operações de empréstimo deverão prever taxa nominal mínima de juros de 6\% ao ano, podendo ser aumentada até o limite de $8 \%$ ao ano para pessoas físicas, setor público ou pessoas jurídicas sem fins lucrativos e até o limite de 9,39\% ao ano para as demais pessoas jurídicas;

- o agente operador pode cobrar, a título de risco de crédito, nas operações de empréstimo, diferencial de juros acrescido às taxas nominais de juros até o limite de $0,8 \%$ ao ano;

- serão cobrados, em acréscimo às taxas de juros nominais, 2,16\% ao ano como remuneração dos agentes financeiros para financiamentos a pessoas físicas e 2,00\% ao ano para pessoas jurídicas e setor público;

- $\quad$ exclusivamente para pessoas físicas, será cobrada uma taxa de acompanhamento da operação pelos agentes financeiros, que varia de $1 \%$ a $3 \%$ do valor do financiamento;

- nas operações com pessoas físicas, será cobrado pelos agentes financeiros valor referente à taxa de administração, componentes dos encargos mensais e reajustáveis anualmente pelo mesmo índice aplicado ao saldo devedor, no valor de R\$ 22,28 / mês (até agosto de 2007) e R\$20,05 / mês (de 1 de setembro de 2007 até 31 de dezembro de 2008).

O FGTS também oferece subsídios diretos à população de baixa renda. A Resolução 460/2004 introduziu o desconto nos financiamentos a pessoas físicas com rendimentos até R\$ 
1.750,00 (limite revisto pela Resolução 501/2006), em operações que observem padrões mínimos de habitabilidade, preferencialmente apresentados de forma coletiva, que serão aplicados para cobertura da remuneração dos agentes financeiros (diferencial de juros e taxa de administração, limitados a 75\% do saldo devedor inicial da operação de financiamento), e para a complementação da capacidade de pagamento do mutuário, limitado a $\mathrm{R} \$ 14.000,00$. Os descontos só poderão ser concedidos uma vez por mutuário e é vedado o acúmulo de descontos do FGTS com os benefícios referentes ao Programa de Subsídio à Habitação - PSH.

Segundo Caixa Econômica Federal (2005), em seu relatório da gestão do FGTS, demonstra no quadro a seguir, os resultados dos recursos alocados e aplicados pelo FGTS.

TABELA 6: METAS E RESUltAdOS FÍSICOS E FINANCEIROS DO FGTS - 2005.

\begin{tabular}{|c|c|c|c|c|c|c|c|c|c|}
\hline \multirow[b]{3}{*}{ Descrição } & \multicolumn{6}{|c|}{ METAS FINANCEIRAS } & \multicolumn{3}{|c|}{ METAS FÍSICAS } \\
\hline & \multirow[b]{2}{*}{$\begin{array}{c}\text { RS } \\
\text { Orçamento } \\
\text { Final }\end{array}$} & \multirow[b]{2}{*}{$\begin{array}{c}\text { RS } \\
\text { Alocado aos } \\
\text { Agentes } \\
\text { Financeiros }\end{array}$} & \multirow[b]{2}{*}{$\begin{array}{c}\% \\
\text { Alocado/ } \\
\text { Orçado }\end{array}$} & \multicolumn{3}{|c|}{ REALIZADO } & \multirow[b]{2}{*}{$\begin{array}{l}\text { Unidades } \\
\text { Previsto }\end{array}$} & \multirow[b]{2}{*}{$\begin{array}{l}\text { Unidades } \\
\text { Realizado }\end{array}$} & \multirow[b]{2}{*}{$\begin{array}{c}\% \\
\text { Alcançado } \\
\text { (Realizado/ } \\
\text { Estipulado) }\end{array}$} \\
\hline & & & & $\begin{array}{c}\text { RS } \\
\text { Valor }\end{array}$ & $\begin{array}{c}\text { \% } \\
\text { Alcançado } \\
\text { (Realizado/ } \\
\text { Orçamento) }\end{array}$ & $\begin{array}{c}\text { \% } \\
\text { Alcançado } \\
\text { (Realizado/ } \\
\text { Alocado) }\end{array}$ & & & \\
\hline Total Habitação & 6.850 .000 & 6.621 .450 & $96,66 \%$ & 5.193 .786 & $75,82 \%$ & $78,44 \%$ & 465.865 & 320.779 & $68,86 \%$ \\
\hline Habitação Popular & 5.400 .000 & 5.171 .450 & $95,77 \%$ & 4.204 .297 & $77,86 \%$ & $81,30 \%$ & 422.683 & 292.891 & $69,29 \%$ \\
\hline Carta de Crédito & 5.080 .000 & 4.854 .846 & $95,57 \%$ & 4.186 .297 & $82,41 \%$ & $86,23 \%$ & 384.848 & 292.390 & $75,98 \%$ \\
\hline Individual & 4.185.234 & 3.961 .260 & $94,65 \%$ & 3.762 .760 & $89,91 \%$ & $94,99 \%$ & 317.063 & 268.662 & $84,73 \%$ \\
\hline Associativa Entidades & 760.691 & 760.691 & $100,00 \%$ & 364.122 & $47,87 \%$ & $47,87 \%$ & 57.628 & 13.624 & $23,64 \%$ \\
\hline Associativa COHAB & 134.075 & 132.895 & $99,12 \%$ & 59.415 & $44,31 \%$ & $44,71 \%$ & 10.157 & 10.104 & $99,48 \%$ \\
\hline Apoio à Produção & 70.000 & 70.000 & $100,00 \%$ & 18.000 & $25,71 \%$ & $25,71 \%$ & 2.121 & 501 & $23,62 \%$ \\
\hline Pró-moradia & 250.000 & 246.604 & $98,64 \%$ & - & $0,00 \%$ & $0,00 \%$ & 35.714 & - & - \\
\hline Habitação & 450.000 & 450.000 & $100,00 \%$ & 273.040 & $60,68 \%$ & $60,68 \%$ & 8.182 & 5.184 & $63,36 \%$ \\
\hline Operações Especiais & 350.000 & 350.000 & $100,00 \%$ & 264.865 & $75,68 \%$ & $75,68 \%$ & 8.182 & 5.184 & $63,36 \%$ \\
\hline Carta de Crédito Individual & 215.200 & 215.200 & $100,00 \%$ & 175.948 & $81,76 \%$ & $81,76 \%$ & - & - & - \\
\hline Carta de Crédito Associativa & 134.800 & 134.800 & $100,00 \%$ & 88.917 & $65,96 \%$ & $65,96 \%$ & - & - & - \\
\hline CRI & 100.000 & 100.000 & $100,00 \%$ & 8.175 & $8,18 \%$ & $8,18 \%$ & - & - & - \\
\hline FAR / PAR & 1.000 .000 & 1.000 .000 & $100,00 \%$ & 716.449 & $71,64 \%$ & $71,64 \%$ & 35.000 & 22.704 & $64,87 \%$ \\
\hline
\end{tabular}

Fonte: Caixa Econômica Federal (2005).

Reais correntes.

Pela Tabela 6, vê-se que os recursos alocados para financiamento habitacional pelos programas Carta de Crédito, para Habitação Popular pelo FGTS, em 2005, foram da ordem de $\mathrm{R} \$ 5,08$ bilhões. Destes, foram alocados para os agentes financeiros R 4,85 bilhões, dos quais apenas $\mathrm{R} \$ 4,19$ bilhões foram efetivamente utilizados, aproximadamente $82,4 \%$. O resultado foi que das 422 mil unidades habitacionais planejadas para serem atendidas no exercício de 2005, somente o foram 293 mil unidades. Para o PAR, todos os recursos disponibilizados foram alocados aos agentes financeiros, entretanto, somente 71,6\% foram efetivamente utilizados no arrendamento de habitações. Os outros programas não são voltados ao financiamento da demanda ou atendem faixas de renda acima das aqui estudadas, logo, não serão discutidos. 


\subsubsection{O SBPE - Sistema Brasileiro de Poupança e Empréstimo}

O SBPE é um sistema regulamentado de poupança e crédito especiais para habitação que opera desde a criação do SFH em 1964. O retorno sobre a poupança neste sistema é limitado a $\mathrm{TR}+6 \%$ ao ano, como também o retorno dos empréstimos para habitação é limitado a TR + $12 \%$ ao ano, no âmbito do SFH. Os recursos aplicados na poupança são isentos de Imposto de Renda, o que caracteriza uma forma de subsídio ao sistema.

Os financiamentos habitacionais feitos com recursos do SBPE por intermédio da Carta de Crédito Individual - SBPE, que estão no âmbito do SFH, são direcionados para a população nas faixas de renda média e alta, permitindo financiamentos habitacionais de até $\mathrm{R} \$$ $350.000,00$, taxa de juros máxima de $\mathrm{TR}+12 \%$ ao ano, para um prazo de amortização máximo de 20 anos e um valor máximo de financiamento de $80 \%$ do valor de avaliação do imóvel. Os financiamentos habitacionais feitos com recursos do SBPE por meio da Carteira Hipotecária, fora do âmbito do SFH, são direcionados para a população na faixa de renda alta, não têm limite máximo e são reajustados através da TR mais juros de mercado, sem teto. Por atender um público de média e alta renda, diferente do público-alvo deste trabalho, não serão analisados outros aspectos deste sistema de poupança. O gráfico a seguir representa o número de financiamentos concedidos no âmbito do SFH, para o FGTS e o SBPE.

FIGURA 17: NÚMERO DE FINANCIAMENTOS HABITACIONAIS NO ÂMBITO DO SFH.

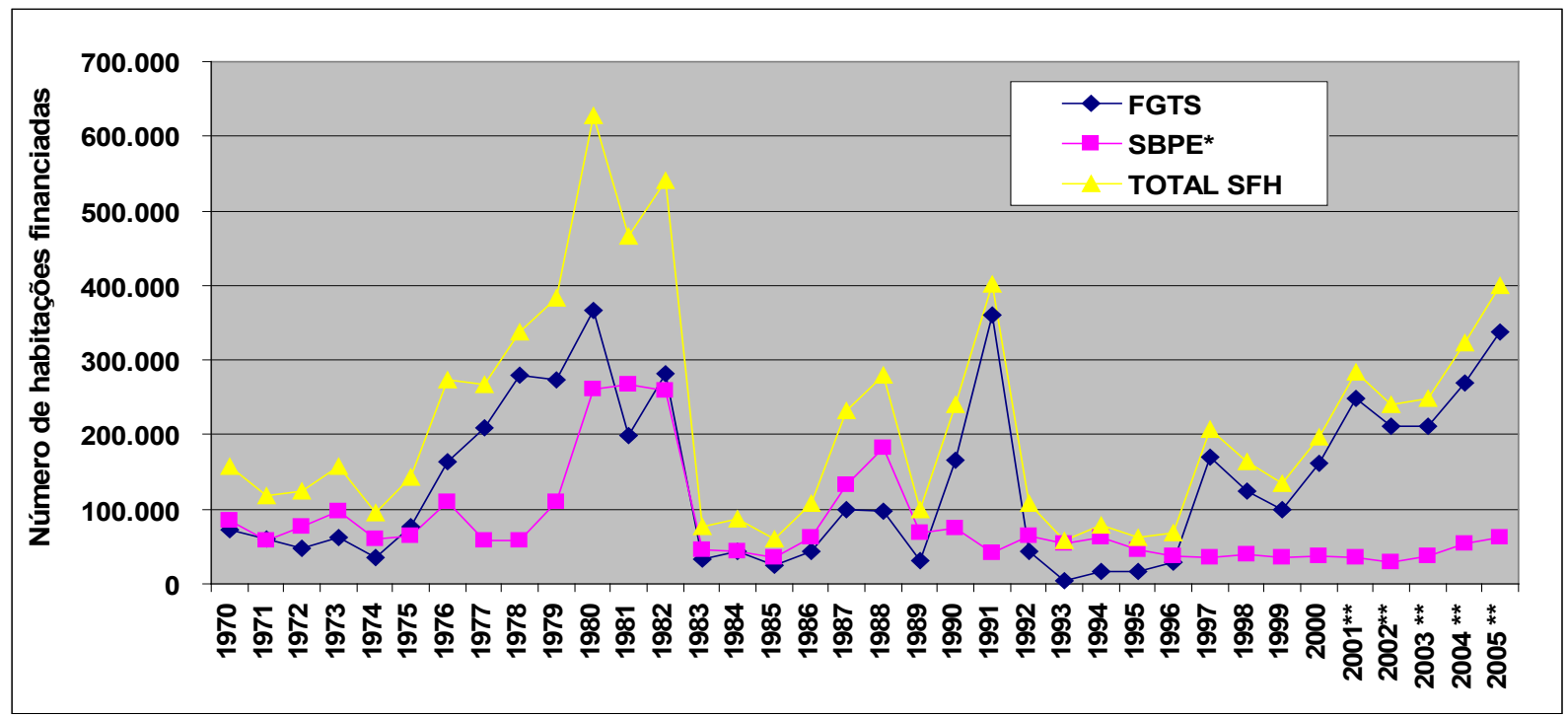

Fonte: Adaptado de CBIC - Câmara Brasileira da Indústria da Construção. Disponível em: $<$ www.cbic.org.br>, acesso em: 15 nov. 2006.

(*) O número de moradias financiadas com recursos do SBPE é obtido pela soma dos financiamentos para a aquisição de imóveis (novos e usados) e para a construção (que a partir de janeiro de 1998 inclui também Materiais de Construção, Reforma e Ampliação).

(**) No FGTS, incluem-se unidades habitacionais financiadas nos programas Carta de Crédito Individual, Material de Construção, Imóvel na Planta / Apoio à Produção e Pró-Moradia. 
No âmbito do SFH, o gráfico anterior representa a quantidade de habitações financiadas com recursos do FGTS e do SBPE, mostrando o auge do sistema no final da década de 1970 e começo da década de 1980. Pode-se notar também o decréscimo da participação do SBPE nos financiamentos habitacionais do SFH na década de 1990, provavelmente em razão da falta de competitividade das taxas de juros da poupança, se comparadas com as taxas de mercado, incentivando a retirada do dinheiro dos poupadores de suas contas de poupança para investimentos em outros ativos alternativos. Pode-se notar, ainda, a recuperação gradativa do sistema a partir de 1997, mas ainda tímida, tendo como fonte de recursos principal o FGTS, vale notar que a população brasileira cresceu de aproximadamente 120 milhões na década de 1980 para cerca de 180 milhões nos dias atuais.

\subsection{Aspectos da Política Nacional de Habitação brasileira voltados ao financiamento habitacional da população de baixa renda}

A Política Nacional de Habitação (PNH) - 2004, segundo o Ministério das Cidades (2004), tem as seguintes diretrizes principais:

- desenvolvimento institucional - estímulo à participação de todos os agentes públicos e privados, da sociedade organizada, dos setores técnicos e acadêmicos na formulação da Política Nacional de Habitação; promoção e apoio à criação de fundos e planos habitacionais nos estados, DF e municípios; e promoção e apoio a ações visando ao aprimoramento e ao desenvolvimento institucional;

- $\quad$ mobilização de recursos - estruturação do SFH para viabilizar maior cooperação entre a União, estados, DF e municípios; ampliação da oferta de recursos não onerosos e perenes; ampliação da utilização dos recursos do FGTS; promoção e apoio a medidas de estimulo à poupança voltadas à habitação;

- $\quad$ identificação da demanda - definição de novos critérios e desenvolvimento de estudos e pesquisas que traduzam melhor as diferenças regionais e socioeconômicas da população para um melhor conhecimento do problema e melhor enquadramento dos beneficiários dos programas habitacionais; formulação de indicadores multidimensionais capazes de combinar os diversos determinantes das necessidades habitacionais; 
- $\quad$ gestão de subsídios - promoção e apoio de mecanismos de transferência de recursos não onerosos para a população de baixa renda sem capacidade de pagar por uma moradia adequada; concessão de subsídios ao consumidor final e não ao imóvel ou aos empreendedores; concessão de subsídios baseados na condição socioeconômica do beneficiário e não no valor do imóvel ou do financiamento; recuperação de parte dos subsídios concedidos ao longo do prazo de financiamento, considerada a evolução socioeconômica das famílias;

- $\quad$ qualidade e produtividade da produção de moradias - melhoria das diversas disciplinas na cadeia produtiva da construção; estímulo à modernização e à criação de ambiente tecnológico e da gestão que guie as ações dos agentes da cadeia produtiva do setor habitacional; elevação da qualidade da mão-de-obra da construção civil; incentivo ao desenvolvimento de pesquisas sobre habitação para a população de baixa renda;

- sistema de informação, avaliação e monitoramento - criação de um sistema de informação, monitoramento e avaliação dos programas e ações no setor habitacional, de forma sistemática, participativa e democrática, abrangendo a concepção, implementação e resultados, garantindo um aprendizado social e institucional sobre as ações e programas do $\mathrm{PNH}$;

- $\quad$ integração da política habitacional à política de desenvolvimento urbano - articulação das políticas habitacionais com as políticas fundiárias, de infra-estrutura, ambiental, transporte e desenvolvimento urbano, para uma melhor integração dos cidadãos; promoção e apoio à regularização de assentamentos informais em imóveis públicos e privados;

- contratos de financiamento habitacional com desequilíbrio financeiro no âmbito do Sistema Financeiro de Habitação - viabilização de mecanismos que permitam a renegociação para adequar os financiamentos à capacidade de pagamento dos beneficiários; definição de instrumentos e mecanismos para viabilizar soluções para problemas financeiros das COHAB's junto à União, estados, DF e agentes financeiros. 
A Política Nacional de Habitação prevê também a criação de um sistema habitacional que esteja focado na solução das necessidades habitacionais da população de baixa renda. Para isso, foi criado, pela Lei 11.124/2005, o Sistema Nacional de Habitação de Interesse Social (SNHIS), com o objetivo de:

- viabilizar para a população de menor renda o acesso à terra urbanizada e à habitação sustentável;

- implementar políticas e programas de investimentos e subsídios, promovendo e viabilizando o acesso à habitação voltada à população de baixa renda; e

- $\quad$ articular, compatibilizar, acompanhar e apoiar a atuação das instituições e órgãos que desempenham funções no setor da habitação.

O SNHIS centralizará todos os programas e projetos voltados à habitação de interesse social no Brasil. Seu principal objetivo é o de garantir que os recursos públicos previstos sejam realmente destinados a subsidiar a população de baixa renda, situadas nas faixa de renda até 5 SM, na qual se concentra a maioria do déficit habitacional brasileiro. Este buscará compatibilizar e integrar as políticas habitacionais federais, estaduais, do DF e municipais, bem como as demais políticas de desenvolvimento urbano, ambiental e de inclusão social. São recursos do SNHIS, segundo a lei 11.124/2005:

- $\quad$ Fundo de Amparo ao Trabalhador - FAT, nas condições estabelecidas em seu Conselho Deliberativo;

- $\quad$ Fundo de Garantia do Tempo de Serviço - FGTS, nas condições estabelecidas em seu Conselho Curador;

- $\quad$ Fundo Nacional de Habitação de Interesse Social - FNHIS; e

- $\quad$ outros fundos ou programas que vierem a ser incorporados ao SNHIS.

A mesma lei que criou o SNHIS também instituiu o FNHIS, fundo de natureza contábil, com o objetivo de centralizar e gerenciar recursos orçamentários para os programas estruturados 
no âmbito do SNHIS, destinados a implementar políticas habitacionais direcionadas à população de menor renda. Ainda segundo a lei 11.124/2005, o FNHIS tem as seguintes características principais:

- $\quad$ é constituído por recursos do Fundo de Apoio ao Desenvolvimento Social; dotações do Orçamento Geral da União, classificadas na função habitação; contribuições e doações de pessoas físicas e jurídicas, entidades e organismos de cooperação nacionais ou internacionais; receitas operacionais e patrimoniais de operações realizadas com recursos do FNHIS; e outros recursos que lhe vierem a ser destinados. O FNHIS será gerido por um Conselho Gestor a ser composto de forma paritária por órgãos e entidades do Poder Executivo e representantes da sociedade civil;

- $\quad$ seus recursos serão destinados a ações vinculadas aos programas de habitação de interesse social que contemplem - aquisição, construção, conclusão, melhoria, reforma, locação social e arrendamento de unidades habitacionais em áreas urbanas e rurais; produção de lotes urbanizados para fins habitacionais; urbanização, produção de equipamentos comunitários, regularização fundiária e urbanística de áreas caracterizadas de interesse social; implantação de saneamento básico, infra-estrutura e equipamentos urbanos, complementares aos programas habitacionais de interesse social; aquisição de materiais para construção, ampliação e reforma de moradias, recuperação ou produção de imóveis em áreas encortiçadas ou deterioradas, centrais ou periféricas, para fins habitacionais de interesse social; e outros programas e intervenções na forma aprovada pelo Conselho Gestor do FNHIS;

seus recursos serão aplicados de forma descentralizada, por meio de estados, DF e municípios que, por sua vez devem constituir fundo, com dotação orçamentária própria, destinado a implementar Política de Habitação de Interesse Social e receber recursos do FNHIS; constituir conselho que contemple a participação de entidades públicas e privadas, e de segmentos da sociedade ligados à área de habitação; apresentar Plano Habitacional de Interesse Social, considerando as especificidades do local e da demanda; firmar termo de adesão ao SNHIS; e elaborar relatórios da gestão. A transferência de recursos do FNHIS para estados, DF e municípios fica condicionada à existência de contrapartida destes, podendo esta se dar em recursos financeiros, bens imóveis urbanos ou serviços; e 
- $\quad$ os benefícios concedidos no âmbito do SNHIS poderão ser representados por - subsídios financeiros destinados a complementar a capacidade de pagamento das famílias beneficiárias; isenção ou redução de impostos municipais, distritais, estaduais ou federais, incidentes sobre o empreendimento no processo construtivo; outros benefícios não caracterizados como subsídios financeiros, destinados a cobrir ou reduzir o custo de construção.

\subsection{Programas federais para o financiamento habitacional da população de baixa renda}

As condições dos programas de financiamento e os valores apresentados a seguir são referentes às condições vigentes, em moeda corrente, no exercício de 2006.

\subsubsection{Programa de Subsídio à Habitação - PSH}

Segundo o Ministério as Cidades (2006, p.26), o PSH objetiva oferecer acesso à moradia adequada a cidadãos de baixa renda por intermédio da concessão de subsídios.

O público-alvo do PSH é a população com renda mensal familiar até 3SM. O programa oferece subsídios para a complementação do preço de compra/venda ou construção de unidades habitacionais. O PSH é operado com recursos provenientes do Orçamento Geral da União (OGU) e conta com contrapartida de estados, DF e municípios, sob a forma de complementação dos subsídios oferecidos pelo programa.

O PSH é um programa que envolve grande parceria entre o Governo Federal, os governos locais $^{38}$, as instituições financeiras habilitadas e os beneficiários. O processo começa com a oferta pública de recursos (leilão) pelo Ministério das Cidades, que objetiva selecionar as instituições financeiras com os menores custos de operação. As instituições financeiras ficam responsáveis pelo recebimento das propostas de participação no programa dos governos locais.

\footnotetext{
${ }^{38}$ A expressão "governos locais" refere-se aos governos estaduais, DF e municipais.
} 
Os governos locais organizam os grupos de cidadãos a serem beneficiados pelo programa e apresentam, às instituições financeiras habilitadas, propostas de empreendimentos habitacionais. Os governos locais devem aportar contrapartida, em complemento aos recursos repassados do OGU.

Uma vez selecionados, os beneficiários ficam responsáveis por contratar financiamento habitacional junto às instituições financeiras habilitadas, da parte não coberta pelo subsídio. $\mathrm{O}$ comprometimento da renda máximo é de $20 \%$ da renda familiar bruta, prazo máximo de amortização da parte não subsidiada é de 72 meses. Os juros máximos cobrados para a parte não subsidiada é de TR $+6 \%$ ao ano e o PSH cobre os demais componentes de custos e de remuneração do agente financeiro.

Os limites operacionais dos subsídios destinados à complementação dos valores de produção/aquisição de moradias estão delineados na seqüência.

- $\quad$ Para a produção de moradias:

- municípios integrantes de regiões metropolitanas - varia entre $\mathrm{R} \$ 3.500,00$ e $\mathrm{R} \$$ $6.000,00 ; \mathrm{e}$

- municípios não integrantes de regiões metropolitanas - varia entre $\mathrm{R} \$ 2.000,00$ e $\mathrm{R} \$$ $4.500,00$.

- Para aquisição de moradias:

- não será superior a $\mathrm{R} \$ 4.500,00$.

Os valores máximos de investimento ou avaliação das unidades habitacionais são:

- $\quad$ R $\$ 28.000$ em municípios integrantes de regiões metropolitanas;

- $\quad$ R\$ 20.000 em municípios não integrantes de regiões metropolitanas; e

- $\quad$ R\$ 30.000 em municípios integrantes das regiões metropolitanas das capitais de São Paulo e Rio de Janeiro. 


\subsubsection{Carta de Crédito Individual - FGTS}

Segundo a Caixa Econômica Federal (2006a, p.8), “o objetivo do programa é de possibilitar o acesso à moradia, em área urbanas ou rurais, por intermédio da concessão de financiamentos a pessoas físicas integrantes da população alvo do Fundo de Garantia do Tempo de Serviço FGTS".

O público-alvo é o mesmo do FGTS, ou seja, Habitação Popular, aqueles com renda familiar bruta até R \$ 3.900,00 (até 2008 este limite diminuirá para R \$ 2.600); e Habitação/Operações Especiais, aqueles com renda familiar bruta de R\$ 3.900,01 a R\$ 4.900,00 (esta faixa de atendimento será extinta até 2008).

Dos recursos alocados pelo agente operador ao agente financeiro, pelo menos $20 \%$ deve ser direcionado para a população com renda familiar de até $\mathrm{R} \$ 1.750,00$. Também terão preferência as propostas dos agentes financeiros que apresentarem maior volume de recursos para o financiamento habitacional de famílias nesta faixa de renda.

O financiamento pela Carta de Crédito Individual utiliza os recursos do FGTS e permite a contratação das seguintes modalidades: aquisição de unidade habitacional nova e usada; construção de unidade habitacional; conclusão, ampliação, reforma ou melhoria de unidade habitacional; aquisição de lote urbanizado; e aquisição de material de construção. Os recursos destinados à área de Operações Especiais ficam restritos às modalidades de aquisição de unidade habitacional nova e construção de unidade habitacional.

A atualização monetária dos financiamentos será calculada sobre o saldo devedor, com base no mesmo índice e na mesma periodicidade de atualização das contas vinculadas do FGTS. As taxas nominais de juros cobradas serão de 6,00\% ao ano para Habitação Popular e 8,00\% ao ano para Habitação/Operações Especiais.

A contrapartida mínima ${ }^{39}$ do mutuário é de 5\% para imóveis novos e 7,5\% para imóveis usados, sobre o valor de venda ou avaliação. O comprometimento máximo permitido da renda

\footnotetext{
${ }^{39}$ A contrapartida mínima é aplicada sobre o valor de venda ou investimento do imóvel e representa a parte não financiável pelo FGTS. O valor de avaliação é atribuído por equipe técnica especializada do
} 
mensal do mutuário é de $30 \%$ da renda familiar apurada, verificado isto na celebração do financiamento. O prazo máximo de amortização dos financiamentos é de 25 anos para imóveis usados e 30 anos para imóveis novos. Embora estes sejam os limites máximos impostos pelo CCFGTS para comprometimento de renda e prazos de amortização dos financiamentos, os limites efetivamente utilizados são inferiores a estes, como será descrito no Capítulo 5.

Como remuneração do agente financeiro, será cobrado um diferencial variável de $1,70 \%$ a 2,16\% ao ano, incidente sobre o saldo devedor, cobrado no encargo mensal. Como taxa de administração para operações com pessoa física, reajustada anualmente pelo mesmo índice aplicado ao saldo devedor, serão cobrados R \$22,28 / mês (até agosto de 2007) e R\$20,05 / mês (de 1 de setembro de 2007 até 31 de dezembro de 2008). Como taxa de acompanhamento da operação, o agente financeiro pode, também, cobrar do mutuário pessoa física, valor a ser pago ou deduzido mensalmente e proporcionalmente a cada desembolso, como pela tabela a seguir.

TABELA 7: TAXAS DE ACOMPANHAMENTO DE OPERAÇÃO.

\begin{tabular}{c|c}
\hline \hline $\begin{array}{c}\text { Serviços prestados pelos agentes } \\
\text { financeiros }\end{array}$ & Percentual sobre o valor do financiamento \\
\hline $\begin{array}{c}\text { Acompanhamento de obras e serviços } \\
\text { (operações individuais) }\end{array}$ & $3 \%$ \\
\hline $\begin{array}{c}\text { Acompanhamento de obras e serviços } \\
\text { (operações coletivas) }\end{array}$ & $2 \%$ \\
\hline Avaliação & $1 \%$ \\
\hline \hline
\end{tabular}

Fonte: Caixa Econômica Federal (2006a).

Os limites máximos de financiamento são os mesmos descritos na Tabela 5.

Os financiamentos aos mutuários pessoas físicas, com renda familiar mensal até $\mathrm{R} \$ 1.750,00$, podem ser beneficiados com a concessão do "Desconto", subsídio direto cujo valor é levado a débito do FGTS. Este desconto será concedido para financiamentos vinculados a imóveis que observem os padrões mínimos de habitabilidade, que são: conformidade com a legislação ambiental e ocupação do solo; acesso por via pública e integração à malha e equipamentos 
urbanos; e existência de soluções de abastecimento de água e esgotamento sanitário, iluminação pública e ligação interna de energia elétrica. Ele é concedido preferencialmente por intermédio de operações apresentadas de forma coletiva na área de habitação popular e é concedido de duas formas, como segue:

- $\quad$ desconto para fins de cobertura da remuneração dos agentes financeiros - o diferencial de juros referente à remuneração do agente financeiro e a taxa de administração são suportados pelo FGTS; e

- desconto para fins de complementação da capacidade de pagamento do beneficiário funciona como um subsídio direto e é dado de uma vez na contratação do financiamento. Limitado a R\$ 14.000,00, o valor deste desconto equivale a um cálculo específico, definido na Resolução 460/04 do CCFGTS, que leva em consideração vários fatores, como a faixa de renda do mutuário, a localização do imóvel, o limite de avaliação ou investimento do imóvel, o valor financiado do imóvel e a participação mínima presumida do mutuário.

O Desconto só poderá ser concedido uma vez por mutuário e é vedado o acúmulo desse desconto com os benefícios referentes ao Programa de Subsídio à Habitação - PSH.

\subsubsection{Carta de Crédito Associativa - FGTS}

Segundo com o Ministério das Cidades (2006, p.38), "o programa objetiva conceder financiamentos a pessoas físicas, associadas em grupos formados por condomínios, sindicatos, cooperativas, associações, Companhias de Habitação (COHAB) ou empresas do setor da construção civil".

O financiamento pela Carta de Crédito Associativo utiliza os recursos do FGTS e permite a contratação das seguintes modalidades: produção de lote urbanizado, a construção habitacional ou a aquisição de unidade nova produzida no âmbito do próprio programa. 
$\mathrm{Na}$ Carta de Crédito Associativa, diferentemente da Carta de Crédito Individual, existe a figura da entidade organizadora do grupo associativo, que, segundo o Ministério das Cidades (2006), tem as seguintes atribuições principais:

- $\quad$ formação organização e análise sócio-econômica prévia dos proponentes do grupo associativo;

- $\quad$ elaboração e estudo prévio de viabilidade dos projetos;

- $\quad$ acompanhamento da execução e conclusão dos projetos; $e$

- $\quad$ execução ou contratação de trabalho de desenvolvimento comunitário junto aos mutuários, nos casos de financiamentos concedidos com recursos da área de Habitação Popular.

Os adquirentes organizados devem possuir renda familiar situada nos patamares do públicoalvo do FGTS. O contrato de financiamento é firmado entre o agente financeiro e o mutuário, a partir do lançamento do empreendimento.

O programa, quando operado com condomínios, sindicatos, cooperativas, associações ou pessoas jurídicas voltadas à produção habitacional, utilizará os recursos do FGTS destinados às áreas de Habitação Popular e Habitação/Operações Especiais. Já quando operado por Companhias de Habitação Popular ou órgãos assemelhados, utilizará recursos referentes à área de Habitação Popular, exclusivamente.

Os recursos são liberados pelo agente financeiro em parcelas mensais, de acordo com o cronograma físico-financeiro estabelecido contratualmente, com base em relatório técnico de acompanhamento emitido pelo agente financeiro.

As condições gerais do financiamento habitacional aos mutuários são semelhantes às apresentadas para a Carta de Crédito Individual, como comprometimento de renda, contrapartida, limites de financiamentos, juros, prazo de amortização, remuneração do agente financeiro, taxa de administração, taxa de acompanhamento de operação e descontos. 


\subsubsection{Programa de Arrendamento Residencial - PAR}

Segundo o Ministério das Cidades (2006, p.57),

o programa de Arrendamento Residencial (PAR) tem por objetivo propiciar moradia à população de baixa renda, sob a forma de arrendamento residencial com opção de compra. [...].O PAR é uma operação de aquisição de empreendimentos novos, a serem construidos, em construção ou a recuperar/reformar.

O público-alvo do PAR é a população com renda familiar até 6SM. Os recursos vêm do Fundo de Arrendamento Residencial (FAR), criado exclusivamente para o programa, composto de recursos onerosos vindos de empréstimos junto ao FGTS e recursos não onerosos provenientes do FAS, FINSOCIAL, FDS e PROTECH.

O sistema utilizado no PAR engloba o financiamento à produção e o arrendamento com opção de compra. As empresas construtoras apresentam propostas de aquisição e produção de empreendimentos à $\mathrm{CEF}$, que são submetidas às análises técnica e de risco do empreendimento, como também às análises jurídica do proponente e de regularidade e legalidade do empreendimento. A liberação de recursos pelas obras executadas é feita em parcelas mensais, condicionadas ao cumprimento do cronograma físico acordado.

Após a conclusão do empreendimento, as unidades são arrendadas. O Poder Público local identifica as famílias a serem beneficiadas. A CEF realiza a seleção dos arrendatários por meio de análise cadastral e apuração da renda familiar bruta. Fica ao cargo do arrendatário a conservação do imóvel.

Os empreendimentos do programa devem atender as seguintes condições e características básicas, que, segundo o Ministério das Cidades (2006, p.58), são:

- $\quad$ ser inseridas na malha urbana, contar com a existência prévia de infraestrutura básica que permita as ligações domiciliares de abastecimento de água, esgotamento sanitário e energia elétrica, bem com vias de acesso a transportes públicos;

- obedecer as especificações técnicas mínimas estabelecidas pelo programa;

- ter o valor máximo de aquisição por unidade conforme o quadro a seguir: 
TABELA 8: VALOR MÁXIMO DE AQUISIÇÃO DE UNIDADES HABITACIONAIS PARA ARRENDAMENTO PELO PAR.

\begin{tabular}{|c|c|c|}
\hline UF & Localidade & $\begin{array}{l}\text { Valor máximo de } \\
\text { aquisição (R\$) }\end{array}$ \\
\hline \multirow{2}{*}{ RJ e SP } & $\begin{array}{l}\text { Municípios integrantes das Regiões } \\
\text { Metropolitanas, Municípios de Jundiaí e } \\
\text { São José dos Campos. }\end{array}$ & $40.000,00$ \\
\hline & $\begin{array}{l}\text { Demais municípios com população urbana } \\
\text { superior a } 100 \text { mil habitantes. }\end{array}$ & $34.000,00$ \\
\hline \multirow{2}{*}{ MG } & $\begin{array}{l}\text { Municípios integrantes das Regiões } \\
\text { Metropolitanas. }\end{array}$ & $34.000,00$ \\
\hline & $\begin{array}{l}\text { Demais municípios com população urbana } \\
\text { superior a } 100 \text { mil habitantes. }\end{array}$ & $33.000,00$ \\
\hline \multirow{2}{*}{ BA e PE } & $\begin{array}{l}\text { Municípios integrantes das Regiões } \\
\text { Metropolitanas. }\end{array}$ & $32.000,00$ \\
\hline & $\begin{array}{c}\text { Demais municípios com população urbana } \\
\text { superior a } 100 \text { mil habitantes. }\end{array}$ & $30.000,00$ \\
\hline RS e PR & \multirow{4}{*}{$\begin{array}{l}\text { Capitais estaduais, municípios integrantes } \\
\text { de regiões metropolitanas, se for o caso, e } \\
\text { municípios com população urbana } \\
\text { superior a } 100 \text { mil habitantes. }\end{array}$} & $34.000,00$ \\
\hline$S C, A C, A M, R O$ e $R R$ & & $33.000,00$ \\
\hline AP, PA, TO, ES, GO, MT e MS & & $32.000,00$ \\
\hline$A L, C E, S E, P B, P I, R N$ e MA & & $30.000,00$ \\
\hline
\end{tabular}

Fonte: Ministério as Cidades (2006).

$\mathrm{O}$ arrendamento das unidades habitacionais será feito pela CEF e se dará considerando-se as condições básicas descritas na tabela a seguir. 
TABELA 9: CONDIÇÕES BÁSICAS DOS CONTRATOS DE ARRENDAMENTO.

\begin{tabular}{|c|c|}
\hline Valor inicial da taxa de arrendamento & $\begin{array}{l}0,7 \% \text { do valor de aquisição da unidade. } \\
\text { Nos casos com especificação técnica mínima e } \\
\text { destinados a famílias com renda até } 4 \mathrm{SM} \text {, a } \\
\text { taxa de arrendamento será calculada a base de } \\
0,5 \% \text { do valor de aquisição da unidade. }\end{array}$ \\
\hline $\begin{array}{l}\text { Requisitos básicos do proponente ao } \\
\text { arrendatário }\end{array}$ & $\begin{array}{l}\text { Renda familiar até } 6 \mathrm{SM} \text {; } \\
\text { Não ser proprietário ou promitente comprador de } \\
\text { imóvel residencial em qualquer local do país; } \\
\text { Apresentar idoneidade cadastral; } \\
\text { Possuir capacidade de pagamento. }\end{array}$ \\
\hline Prazo do contrato de arrendamento & 15 anos \\
\hline Reajuste das taxas de arrendamento & $\begin{array}{l}\text { Periodicidade: Anual } \\
\text { Indexador: TR acumulado no período }\end{array}$ \\
\hline Reajuste do valor do imóvel arrendado & $\begin{array}{l}\text { Periodicidade: Anual } \\
\text { TR - para reajuste das parcelas do } \\
\text { arrendamento } \\
80 \% \text { da TR - para reajuste do preço da } \\
\text { habitação }\end{array}$ \\
\hline Opção de compra & Opção de compra findo o prazo contratual \\
\hline
\end{tabular}

Fonte: Ministério as Cidades (2006).

Alves (2006, p.11) assinala que,

[...] o PAR é o único programa em que o acesso à moradia não se dá por crédito imobiliário, ainda que haja a previsão de passar a propriedade para o beneficiário ao final de 180 meses. [...]. Tem sido o programa de maior impacto no déficit habitacional, em especial na região Nordeste, por concentrar forte subsídio no valor da taxa de arrendamento. Além do subsídio concedido na taxa de arrendamento, ao saldo do valor do imóvel não é aplicado taxa de juros, apenas correção monetária. 


\subsubsection{Programa Crédito Solidário}

Segundo com o Ministério das Cidades (2006, p.62),

[...] o programa é voltado ao atendimento de necessidades habitacionais da população de baixa renda, organizada por cooperativas ou por associações com fins habitacionais, visando a produção de novas habitações, a conclusão e reforma de moradias existentes, mediante concessão de financiamento diretamente ao beneficiário, pessoa física.

As modalidades que o programa atende são: aquisição de imóvel novo residencial urbano; aquisição de terreno e construção; construção em terreno próprio; conclusão, reforma e/ou ampliação; e aquisição de material de construção para construção de unidade habitacional.

O seu público-alvo são famílias, organizadas de forma associativa, com renda bruta mensal de até 3SM, residentes em áreas urbanas ou rurais. É admitida também a participação de famílias com renda bruta até 5SM, limitadas a 35\% de composição do grupo associativo (no caso de propostas apresentadas em municípios integrantes de regiões metropolitanas e capitais estaduais; e $25 \%$ de composição de grupo associativo, no caso de propostas apresentadas nos demais municípios e áreas rurais).

O sistema utilizado no programa Crédito Solidário engloba o financiamento à produção e o financiamento à comercialização. O programa é operado com recursos do Fundo de Desenvolvimento Social (FDS), do qual a CEF é o agente operador. Cabe a ela contratar, em nome do FDS, operações de empréstimo com os agentes financeiros por ela habilitados a participar do programa. Cabe aos agentes financeiros as operações de financiamento com os beneficiários finais do programa e realizar o acompanhamento da execução das respectivas obras e serviços. Os valores máximos para os financiamentos são:

TABELA 10: VALORES MÁXIMOS DOS FINANCIAMENTOS PARA O PROGRAMA CRÉDITO SOLIDÁRIO.

\begin{tabular}{c|c|c|c|c}
\hline \hline $\begin{array}{c}\text { Modalidades } \\
\text { Operacionais }\end{array}$ & $\begin{array}{c}\text { Municípios com } \\
\text { população até 50 } \\
\text { mil habitantes e } \\
\text { áreas rurais }\end{array}$ & $\begin{array}{c}\text { Municípios com } \\
\text { população } \\
\text { superior a 50 mil } \\
\text { habitantes }\end{array}$ & $\begin{array}{c}\text { Municípios } \\
\text { integrantes de } \\
\text { Regiões } \\
\text { Metropolitanas }\end{array}$ & $\begin{array}{c}\text { Municípios } \\
\text { integrantes de } \\
\text { Regiões } \\
\text { Metropolitanas de } \\
\text { São Paulo e Rio de } \\
\text { Janeiro }\end{array}$ \\
\hline \hline $\begin{array}{c}\text { Conclusão, ampliação } \\
\text { e reforma }\end{array}$ & $\mathrm{R} \$ 7.500,00$ & $\mathrm{R} \$ 10.000,00$ & $\mathrm{R} \$ 10.000,00$ & $\mathrm{R} \$ 10.000,00$ \\
\hline Demais modalidades & $\mathrm{R} \$ 10.000,00$ & $\mathrm{R} \$ 10.000,00$ & $\mathrm{R} \$ 20.000,00$ & $\mathrm{R} \$ 25.000,00$ \\
\hline \hline
\end{tabular}

Fonte: Caixa Econômica Federal (2006c). 
Os financiamentos cobrirão no máximo $95 \%$ do valor do investimento, para um prazo máximo de 20 anos, com taxa de juros zero e limite de comprometimento de renda máximo de $25 \%$ da renda familiar bruta. $\mathrm{O}$ saldo devedor e as prestações serão atualizados mensalmente pela TR.

O FDS, operado pela CEF, objetiva o financiamento de projetos de investimento de interesse social nas áreas de habitação popular, sendo permitido também o financimaneto nas áreas de saneamento e infraestrutura, desde que vinculados aos programas de habitação, bem como equipamentos comunitários. Constituem recursos deste Fundo os provenientes da aquisição compulsória de cotas de sua emissão pelos fundos de aplicação financeira, na forma da regulamentação expedida pelo Banco Central; os provenientes da aquisição voluntária de cotas de emissão por pessoas físicas ou jurídicas; o resultado de suas aplicações; e outros que lhe venham a ser atribuídos.

\subsubsection{Programas Habitar-Brasil e Pró-Moradia}

Os programas Habitar-Brasil e Pró-Moradia são relativamente pequenos e não têm como objetivo o financiamento habitacional de pessoas físicas para aquisição de moradias adequadas, mas sim oferecer financiamentos a estados e municípios para projetos de infraestrutura para habitação e projetos específicos de habitação para a população de baixa renda.

O programa Habitar-Brasil busca fortalecer a capacidade dos municípios para atuar na melhoria das condições habitacionais da população de baixa renda e desenvolver obras e serviços para regularização e urbanização de assentamentos precários, complementados com ações voltadas para o desenvolvimento comunitário da população residente e a regularização fundiária (MINISTÉRIO AS CIDADES, 2006).

O programa Pró-Moradia financia, com recursos onerosos do FGTS, estados, municípios e DF para oferecer acesso à moradia adequada à população em situação de vulnerabilidade social e com rendimento familiar mensal preponderante de até 3SM. As modalidades operacionais aceitas pelo programa são: urbanização e regularização de assentamentos precários, produção de conjuntos habitacionais e desenvolvimento institucional destinado a propiciar aumento de eficácia na gestão urbana e na implementação de políticas públicas (MINISTÉRIO DAS CIDADES, 2006). 


\subsubsection{Resumo dos programas federais para o financiamento/arrendamento habitacional da população de baixa renda}

TABELA 11: RESUMO DOS PROGRAMAS FEDERAIS DE FINANCIAMENTO/ARRENDAMENTO HABITACIONAL PARA A POPULAÇÃO DE BAIXA RENDA, EM 2006

\begin{tabular}{|c|c|c|c|c|c|c|c|c|c|}
\hline Programas & $\begin{array}{l}\text { Fonte de } \\
\text { Recursos }\end{array}$ & Proponentes & $\begin{array}{l}\text { Público Alvo } \\
\text { Por Renda }\end{array}$ & $\begin{array}{l}\text { Valor Máximo } \\
\text { da Habitação }\end{array}$ & $\begin{array}{l}\text { Prazo Máximo } \\
\text { do }\end{array}$ & $\begin{array}{c}\text { Contrapartida } \\
\text { Mínima do } \\
\text { Beneficiário }\end{array}$ & $\begin{array}{l}\text { Correção } \\
\text { Monetária } \\
\text { Referencial }\end{array}$ & \begin{tabular}{|} 
Juros \\
sobre o \\
saldo \\
devedor
\end{tabular} & $\begin{array}{c}\text { Recursos } \\
\text { alocados para } \\
\text { o exercício } \\
2006 \\
\text { (mil) } \\
\end{array}$ \\
\hline $\begin{array}{l}\text { Carta de Crédito } \\
\text { Individual }\end{array}$ & FGTS & Pessoas físicas & Até 11SM* & $\mathrm{R} \$ \mathbf{8 0 . 0 0 0}$ & 20 anos & $5 \% / 7,5 \%$ & TR & $6 \% * *$ & $\mathrm{R} \$ \mathbf{3 . 2 9 2 . 5 0 0}$ \\
\hline $\begin{array}{l}\text { Carta de Crédito } \\
\text { Associativa }\end{array}$ & FGTS & $\begin{array}{c}\text { Pessoas físicas } \\
\text { organizadas em } \\
\text { entidades associativas }\end{array}$ & Até $11 \mathrm{SM}^{*}$ & $\mathbf{R} \$ \mathbf{8 0 . 0 0 0}$ & 20 anos & $5 \% / 7,5 \%$ & TR & $6 \% * *$ & $R \$ 1.097 .500$ \\
\hline $\begin{array}{l}\text { Desconto FGTS } \\
\text { (Subsídio Direto) }\end{array}$ & FGTS & $\begin{array}{c}\text { Os mesmos dos } \\
\text { Programas Carta de } \\
\text { Crédito }\end{array}$ & Até 5SM & $\begin{array}{c}\text { Subsídio } \\
\text { máximo de } \\
\mathrm{R} \$ 14.000\end{array}$ & \multicolumn{4}{|c|}{$\begin{array}{l}\text { Subsídio ofertado em conjunto com os financiamentos } \\
\text { dos Programas Carta de Crédito }\end{array}$} & $R \$ 1.300 .000$ \\
\hline $\begin{array}{c}\text { Programa de } \\
\text { Arrendamento } \\
\text { Residencial - } \\
\text { PAR }\end{array}$ & $\begin{array}{c}\text { Fundo de } \\
\text { Arredamento } \\
\text { Residencial - } \\
\text { FAR }\end{array}$ & $\begin{array}{c}\text { Pessoas jurídicas na } \\
\text { construção e pessoas } \\
\text { físicas no } \\
\text { arrendamento }\end{array}$ & Até 6SM & $\mathrm{R} \$ \mathbf{4 0 . 0 0 0}$ & 15 anos & Não tem & $\begin{array}{l}\text { TR - Prestação } \\
80 \% \text { TR - Saldo } \\
\text { Devedor }\end{array}$ & $\begin{array}{c}\text { Não é } \\
\text { cobrado }\end{array}$ & $R \$ 1.268 .000$ \\
\hline \begin{tabular}{c|} 
Programa de \\
Subsídio à \\
Habitação - PSH \\
\end{tabular} & OGU & $\begin{array}{l}\text { Governos Locais } \\
\text { depois } \\
\text { pessoas físicas }\end{array}$ & Até 3SM & $\mathbf{R} \$ \mathbf{3 0 . 0 0 0}$ & 6 anos & Não tem & TR & $6 \%$ & $R \$ 150.000$ \\
\hline \begin{tabular}{c|c} 
Programa \\
Crédito Solidário
\end{tabular} & \begin{tabular}{|c|}
$\begin{array}{c}\text { Fundo de } \\
\text { Desenvolvimento } \\
\text { Social- FDS }\end{array}$ \\
\end{tabular} & $\begin{array}{c}\text { Pessoas físicas } \\
\text { organizadas em } \\
\text { entidades associativas }\end{array}$ & Até $5 \mathrm{SM}^{\star * *}$ & $R \$ 40.000$ & 20 anos & $5 \%$ & TR & $\begin{array}{c}\text { Não é } \\
\text { cobrado }\end{array}$ & $R \$ 100.000$ \\
\hline \multicolumn{7}{|c|}{$\begin{array}{l}\text { Fonte Ministério das Cidades (2006) e Caixa Econômica Federal (2006a). } \\
\text { Valores base } 2006 \text {. }\end{array}$} & \multicolumn{2}{|l|}{ TOTAL } & $\mathrm{R} \$ 7.208 .000$ \\
\hline
\end{tabular}

(*) Condições referentes à área de habitação popular.

(**) Taxa de juros aplicáveis aos beneficiários com renda mensal até 5SM.

(***) É admitida a participação de famílias com renda bruta mensal acima de 3SM até 35\% da

composição do grupo associativo. 


\section{DISCUSSÃO}

O objetivo deste Capítulo é discutir a adequação e a suficiência dos programas de financiamento habitacional voltados à população de baixa renda no Brasil, mediante uma análise comparativa entre a capacidade de pagamento e as necessidades da população de baixa renda versus as condições e o volume de recursos ofertados pelos programas federais de financiamento habitacional.

\subsection{Os principais programas de financiamento habitacional atualmente ofertados no Brasil e a população de baixa renda}

Com relação à demanda por habitações, o Brasil enfrenta o desafio de precisar ampliar e reestruturar os programas de financiamento habitacional, de forma a possibilitar o direito ao acesso a habitações adequadas pela população de baixa renda, tanto para as famílias que não vivem em habitações adequadas como para acomodar o surgimento de novas famílias no mesmo estrato. Portanto, para serem suficientes, os recursos destinados aos financiamentos e subsídios habitacionais voltados à população de baixa renda no Brasil deveriam, no mínimo, atender ao crescimento dessa população e contribuir para a redução do número de famílias que moram em habitações inadequadas. Somente a existência e a alocação de recursos para este fim, entretanto, não são suficientes para o enfrentamento desse desafio. É necessário também que a população de baixa renda tenha acesso a esses recursos, possibilitando, assim, o seu acesso também à habitação adequada. Vale salientar que, para enfrentar o desafio descrito, admite-se que a oferta de habitações acompanhará o aumento dos recursos destinados aos financiamentos e subsídios habitacionais, embora não seja este o foco deste trabalho.

\subsubsection{Os financiamentos habitacionais e a capacidade de pagamento da população de baixa renda}

Segundo o World Bank (2002), a principal causa da dificuldade de acesso da população de baixa renda à habitação adequada no Brasil é a relação entre a baixa renda da maioria da população em comparação com o valor de uma unidade habitacional no setor formal. Para que a população de baixa renda possa ter acesso à aquisição da habitação adequada, por intermédio do setor formal, é necessário que esta população tenha acesso a financiamentos 
e/ou subsídios habitacionais que adeqüem e/ou complementem sua capacidade de pagamento ao preço da habitação. Quando isto não acontece, ou ocorre em quantidade e tamanho insuficientes, a população de baixa renda muitas vezes busca o setor informal, dando origem a assentamentos ilegais, favelas, cortiços, loteamentos clandestinos, coabitações etc.

No Brasil, para a população de baixa renda, o Poder Público é a principal fonte de recursos para o financiamento habitacional. No âmbito federal, a maior fonte dos recursos voltados ao financiamento habitacional da população de baixa renda no Brasil é o FGTS. Os recursos do FGTS para o financiamento habitacional já são, em si, uma forma de subsídio implícito, isto porque o FGTS obtém a maioria dos seus recursos através dos recolhimentos compulsórios feitos pelos empregadores em nome dos seus empregados, como explicado no Capítulo anterior, que rendem juros pré-fixados abaixo dos juros de mercado. Isto possibilita que o Governo Federal financie imóveis para a população de baixa renda também com juros préfixados abaixo dos juros de mercado, caracterizando-se, assim, esta operação como um subsídio implícito ao financiamento, pois, caso os assalariados do setor formal pudessem escolher como investir estes recursos, eles provavelmente obteriam retornos maiores do que os obtidos no FGTS, o que encareceria os financiamentos habitacionais. Köhler (2005) entende que os subsídios do FGTS

[...] são extraídos dos titulares das contas vinculadas, dos trabalhadores do setor formal, que, sendo depositantes compulsórios, não têm como se evadir das responsabilidades reais negativas que lhes estão sendo impostas. Entre janeiro de 2000 e dezembro de 2004, para uma variação de 51,01\% no IPCA, os depósitos do FGTS tiveram uma rentabilidade total de 32,89\%. Isso equivale a uma perda real anual de $2,5 \%$.

Esta constatação se faz necessária pelo fato de que, ao longo deste Capítulo, será analisada a adequação dos financiamentos habitacionais federais voltados à população de baixa renda no Brasil, que na maioria dos casos utiliza recursos do FGTS. Portanto, mesmo quando um financiamento mostrar-se adequado a uma certa classe de renda, utilizando recursos do FGTS, é importante saber que estes recursos de financiamento já são subsidiados implicitamente, neste caso, pela própria população em geral, que os paga, mas que também tem acesso a eles para o financiamento das suas habitações. 
Neste item será calculada a capacidade de financiamento da população de baixa renda, por faixa de renda, tendo como fronteiras as condições para tomada dos financiamentos habitacionais descritos no Capítulo 4, destinados a esta população. Será feita, então, uma comparação entre esta capacidade de pagamento e o valor da habitação popular referência, que será descrita a seguir, determinando-se a necessidade da utilização de subsídios diretos para complementar a capacidade de pagamento das faixas de renda estudadas. Serão consideradas neste estudo somente as condições determinadas para aquisição de habitações, embora os programas de financiamento, na maioria das vezes, permitam outras finalidades de utilização dos recursos. Não será considerado o aluguel social como solução habitacional, pela pouca amplitude deste tipo de programa atualmente no País e pela questão cultural ${ }^{40}$, pois a população prefere a aquisição da "casa própria" ao aluguel. Portanto, considerar-se-á que os recursos que poderiam ser destinados a aquisição de habitações pelo Poder Público, para então destiná-las ao aluguel social, seriam destinados ao financiamento da aquisição de moradias adequadas diretamente pelas famílias de baixa renda.

\subsubsection{Habitação popular referência - HPR}

O preço de uma habitação popular pode variar significativamente, dependendo de vários fatores, como: área construída, preço do terreno, materiais, padrão de acabamento, técnicas construtivas, modos de provisão (mutirão, empreitada etc.), tipo de habitação (casa, sobrado, apartamento etc.) etc. Como o objetivo deste trabalho é o de analisar a adequação dos programas de financiamento habitacional e não o valor da habitação popular para a população de baixa renda, que varia caso a caso de acordo com as variáveis citadas, para as análises que serão desenvolvidas neste trabalho será arbitrado um valor de uma habitação popular referência. Não significa dizer que se desprezam os ganhos de produtividade, as características regionais diferenciadas e a busca de tecnologias que propiciem custos menores, mas que, pura e simplesmente, se busca estabelecer uma condição relativa de comparação.

\footnotetext{
${ }^{40}$ Kohara; Piccini (1999, p.9) expressam que "[...] o desejo da casa própria está arraigado em nossa cultura e por isso o aluguel social é visto com restrição [...]."

É importante salientar que aqui não se quer desprezar a importância do aluguel social, que em cenários específicos pode ser a solução mais adequada, mas somente esclarecer que esta solução não será tratada neste trabalho.
} 
Como valor da habitação popular referência (HPR), será considerado a quantia de R\$ $25.260,00^{41}$, necessária para a aquisição da menor habitação adequada.

Este valor será utilizado para a determinação da necessidade de subsídios como complemento da capacidade de financiamento para o acesso da população de baixa renda à menor habitação adequada, representada aqui pela habitação popular referência, não se pretendendo afirmar que este valor represente o valor da habitação popular do País, ou mesmo sua média, mas sim que representa uma referência paramétrica para o desenvolvimento das análises pretendidas, e que, para cada situação regional, estas análises poderão ser realinhadas considerando-se o preço da habitação popular em cada localidade.

\subsubsection{Programas Carta de Crédito Individual e Associativa.}

Como as condições do programa Carta de Crédito Associativa são semelhantes às condições do programa Carta de Crédito Individual com relação a taxa de juros, prazo de amortização, comprometimento de renda, seguros e demais requisitos, diferenciando-se principalmente na forma de contratação, que se dá individualmente ou em grupos de pessoas físicas, estes programas serão tratados aqui em conjunto.

Os programas de Carta de Crédito Individual e Associativa, para a população com rendimento até $5 \mathrm{SM}$, oferecem as seguintes condições para o financiamento habitacional na aquisição de moradias novas:

\footnotetext{
${ }^{41}$ Este valor foi calculado pela média ponderada dos valores da menor habitação permitida pelo PAR, de acordo com a Tabela 20. Como elemento de ponderação, foi considerada a projeção do crescimento do número de famílias de baixa renda por região.
} 
TABELA 12 : CONDIÇõES DE FINANCIAMENTO dos PROGRAMAS CARTA DE CRÉDito

\begin{tabular}{|c|c|}
\hline Correção Monetária e Taxa de Juros & $\mathrm{TR}+6 \%$ ao ano \\
\hline Comprometimento de Renda & $\begin{array}{l}\text { até } 5 \% \text { da renda bruta mensal menor que } 1 \mathrm{SM} \\
\text { até } 10 \% \text { da renda bruta mensal de } 1 \mathrm{SM} \text { até } 3 \mathrm{SM} \\
\text { até } 15 \% \text { da renda bruta mensal de } 3 \mathrm{SM} \text { até } 5 \mathrm{SM}\end{array}$ \\
\hline Prazo Máximo & 240 meses com garantia alienação fiduciária \\
\hline Taxa de Avaliação da Proposta de Aquisição & $1 \%$ sobre o valor da operação \\
\hline Taxa de Administração & Suportado pelo FGTS para estas faixas de renda \\
\hline Remuneração do Agente Financeiro & Suportado pelo FGTS para estas faixas de renda \\
\hline Seguro de Morte e Invalidez Permanente ${ }^{42}$ & $\begin{array}{l}\text { Taxa mensal de } 0,0974 \% \text { sobre o valor do } \\
\text { financiamento }\end{array}$ \\
\hline Seguro de Danos Físicos do Imóvel & $\begin{array}{l}\text { Taxa mensal de } 0,025 \% \text { sobre o valor de avaliação } \\
\text { do imóvel }\end{array}$ \\
\hline Sistema de amortização & SAC - Sistema de Amortização Constante ${ }^{43}$ \\
\hline
\end{tabular}

Fonte: Caixa Econômica Federal (2006a e 2006b).

O limite de comprometimento de renda, de acordo com a Caixa Econômica Federal (2006a), é calculado sobre o valor presente presumido de renda do beneficiário, ou seja, a renda futura do beneficiário, descontando-se o valor dos seguros e taxa de avaliação, é deflacionada aplicando-se uma taxa de juros de $6 \%$ ao ano, pelo prazo do financiamento, achando-se assim a renda total presumida do beneficiário na data do pedido do financiamento, e a este valor aplicam-se os percentuais de comprometimento de renda. A tabela a seguir resume a capacidade de financiamento dentro do programa para cada faixa de renda estudada e o valor dos subsídios e/ou poupança acumulada ${ }^{44}$, necessários ao complemento do preço para aquisição da HPR:

\footnotetext{
${ }^{42} \mathrm{O}$ seguro por morte e invalidez permanente é variável e depende da faixa etária do proponente, sendo $0,0422 \%$ para proponentes até 30 anos, $0,0497 \%$ para proponentes de 31 a 40 anos, $0,0974 \%$ para proponentes de 41 a 50 anos, $0,2130 \%$ para proponentes de 51 a 60 anos, 0,505\% para proponentes de 61 a 70 anos e 1,2622\% para proponentes de 71 a 80 anos. Como nesta simulação não existe um proponente definido, será adotada a faixa intermediária de 41 a 50 anos.

${ }^{43}$ Neste sistema, as prestações são variáveis, a amortização da dívida é constante e igual em cada período, mas os juros são cobrados integralmente sobre o saldo devedor, mês a mês.

${ }^{44}$ Como poupança acumulada, o beneficiário poderá usar também a sua conta vinculada do FGTS, desde que atenda aos requisitos do Fundo para isso.
} 
TABELA 13 : ESTIMATIVA DA CAPACIDADE DE FINANCIAMENTO E DA NECESSIDADE DE SUBSÍDIOS, POR FAIXA DE RENDA, PARA AQUISIÇÃO DA HPR ATRAVÉS DOS PROGRAMAS CARTA DE CRÉDITO

\begin{tabular}{c|c|c|c}
\hline $\begin{array}{c}\text { Renda Bruta } \\
\text { Mensal Familiar }\end{array}$ & $\begin{array}{c}\text { Capacidade de } \\
\text { Financiamento no } \\
\text { Programa }\end{array}$ & $\begin{array}{c}\text { Relação entre } \\
\text { capacidade de } \\
\text { financiamento e o } \\
\text { valor da HPR }\end{array}$ & $\begin{array}{c}\text { Subsídios/Poupança } \\
\text { necessários para } \\
\text { aquisição da HPR }\end{array}$ \\
\hline 1 SM & $\mathrm{R} \$ 4.776$ & $18,9 \%$ & $\mathrm{R} \$ 20.484$ \\
\hline $2 \mathrm{SM}$ & $\mathrm{R} \$ 9.675$ & $38,3 \%$ & $\mathrm{R} \$ 15.585$ \\
\hline $3 \mathrm{SM}$ & $\mathrm{R} \$ 14.508$ & $57,4 \%$ & $\mathrm{R} \$ 10.752$ \\
\hline $4 \mathrm{SM}$ & $\mathrm{R} \$ 28.637^{45}$ & $113,4 \%$ & $\mathrm{R} \$ 1.263$ \\
\hline $5 \mathrm{SM}$ & $\mathrm{R} \$ 35.796$ & $141,7 \%$ & $\mathrm{R} \$ 1.263$ \\
\hline
\end{tabular}

Valores base 2006 .

A Resolução 460/2004 do CCFGTS criou o subsídio direto com recursos do FGTS para a população com renda até 5SM, que, aplicado às faixas de renda estudadas, poderia conceder, mediante a disponibilidade de recursos destinados a este fim, e além dos subsídios suportados pelo FGTS já citados anteriormente referentes à taxa de administração e à remuneração do agente financeiro, os seguintes subsídios:

FIGURA 18: GRÁFICO DA ESTIMATIVA DOS DESCONTOS (SUBSÍDIOS DIRETOS) COM RECURSOS DO FGTS, POR FAIXA DE RENDA

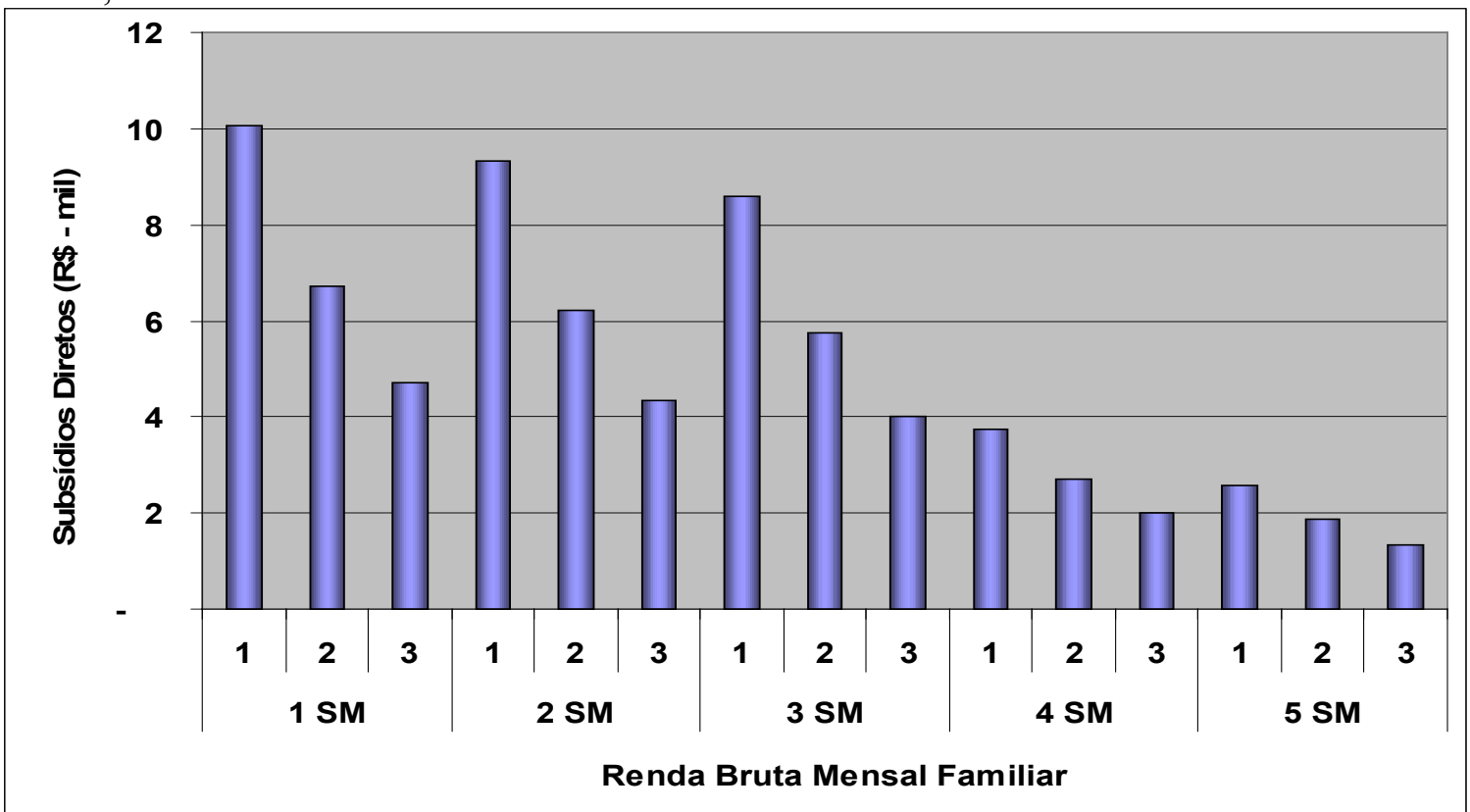

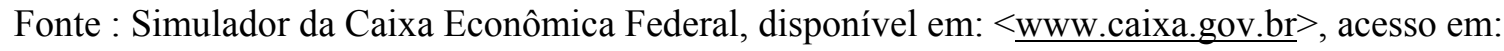
14 nov. 2006.

Valores base 2006. Referente à localização do imóvel:

(1) Municípios integrantes das regiões metropolitanas dos Estados do Rio de Janeiro e São Paulo.

(2) Municípios integrantes de regiões metropolitanas; municípios integrantes de áreas conurbanas ou aglomerados urbanos; municípios sedes de capitais estaduais; ou municípios com população igual ou superior a cem mil habitantes.

(3) Demais municípios não enquadrados nas situações anteriores.

\footnotetext{
${ }^{45}$ Para as faixas de renda de 4SM e 5SM, a capacidade de financiamento poderia cobrir todo o valor da habitação popular referência, mas o financiamento dos Programas Cartas de Crédito somente cobre até $95 \%$ do valor da habitação a ser financiada, ficando por conta do mutuário os $5 \%$ restantes, que este deve pagar com sua conta vinculada do FGTS, poupança acumulada e/ou subsídios diretos do Governo.
} 
Pode-se ver que os subsídios ofertados de acordo com a Resolução 460/2004 do CCFGTS não atendem na totalidade as necessidades de subsídios/poupança para as faixas de renda até 3SM, mesmo considerando o valor máximo do subsídio, tendo como base a aquisição da HPR. Isto mostra que, para estas faixas de renda, os beneficiários teriam de ter poupança acumulada e/ou mesmo subsídios adicionais dos governos locais, além dos financiamentos e subsídios já citados. As famílias com renda mensal de 4SM e 5SM, que já teriam condições de financiar todo o valor da HPR, podem ainda receber subsídios para pagar parte do preço da habitação, inclusive a parte não coberta pelo financiamento.

\subsubsection{Programa de Arrendamento Residencial - PAR}

Inicialmente, é importante esclarecer que o PAR é um programa de arrendamento e não de financiamento habitacional. Nesse programa, o beneficiário paga uma taxa mensal de arrendamento, que corresponde a um percentual do valor do imóvel, durante um período, corrigido anualmente pela inflação. Cada parcela paga é abatida do saldo devedor, também corrigido anualmente pela inflação. Ao final do período de arrendamento, o beneficiário pode optar pela aquisição do imóvel, desde que pague o saldo devedor remanescente. No caso do PAR, como o saldo devedor é reajustado por $80 \%$ do índice inflacionário que reajusta a parcela, e não há cobrança de juros, por ser um programa subsidiado pelo Governo Federal, caso o beneficiário pague as parcelas do arrendamento em dia, ao final do prazo de arrendamento, provavelmente não remanescerá saldo devedor, bastando a opção de aquisição do imóvel. Caso exista saldo devedor, o beneficiário pode optar, ainda, pela renovação do arrendamento. Na desistência do beneficiário durante o arrendamento ou de inadimplência, acima dos limites estabelecidos, o beneficiário não terá direito à restituição dos valores pagos.

O PAR será considerado nesta análise por ter características semelhantes a um financiamento habitacional, quando o beneficiário efetua todos os pagamentos das parcelas do arrendamento. Este programa é voltado à população com renda mensal até 6SM e oferece as seguintes condições para arrendamento de moradias novas: 
TABELA 14 : CONDIÇÕES DE ARRENDAMENTO NO PAR

\begin{tabular}{l|l}
\hline Correção Monetária e Taxa de Juros & $\begin{array}{l}\text { TR - para reajuste das parcelas do arrendamento } \\
80 \% \text { da TR - para reajuste do preço da } \\
\text { habitação } \\
\text { Não há juros no PAR }\end{array}$ \\
\hline Prazo Máximo & 180 meses \\
\hline Seguro de Morte e Invalidez Permanente & $\begin{array}{l}\text { Taxa mensal de } 0,0974 \% \text { sobre o valor do } \\
\text { arrendamento }\end{array}$ \\
\hline Seguro de Danos Físicos do Imóvel & Suportado pelo FAR \\
\hline Taxa de Arrendamento & $\begin{array}{l}\text { Inicial de 0,7\% do valor do imóvel, com } \\
\text { atualização pela TR a cada período de } 12 \text { meses } \\
\text { Inicial de 0,5\% do valor do imóvel, com } \\
\text { atualização pela TR a cada período de } 12 \text { meses, } \\
\text { renda até 4SM }\end{array}$ \\
\hline
\end{tabular}

Fonte : Ministério das Cidades (2006)

O PAR não define um percentual de comprometimento máximo de renda para o programa, sendo determinado apenas que caberá à Caixa Econômica Federal fazer uma análise cadastral das famílias, verificando sua renda familiar mensal bruta e a margem desta renda disponível para comprometimento com as despesas com o arrendamento. Para fim de análise da capacidade de pagamento, será adotado neste trabalho $20 \%$ como o comprometimento máximo da renda familiar mensal bruta de cada família a ser destinado à habitação, valor este encontrado no item 3.5 como o percentual médio das despesas destinadas à habitação no orçamento familiar para as famílias com renda mensal até 5 SM. Este valor também é o mesmo comprometimento máximo de renda determinado pelo $\mathrm{PSH}$, programa com um público próximo ao do PAR. Assim, a capacidade de arrendamento, considerando-se o arrendamento da HPR, para as faixas de renda estudadas, está expressa na tabela a seguir.

TABELA 15 : ESTIMATIVA DA CAPACIDADE DE ARRENDAMENTO E NECESSIDADE DE SUBSÍDIOS, POR FAIXA DE RENDA, PARA ARRENDAMENTO DA HPR ATRAVÉS DO PAR

\begin{tabular}{c|c|c|c}
\hline $\begin{array}{c}\text { Renda Bruta Mensal } \\
\text { Familiar }\end{array}$ & $\begin{array}{c}\text { Capacidade de } \\
\text { Arrendamento no } \\
\text { Programa }\end{array}$ & $\begin{array}{c}\text { Relação entre } \\
\text { capacidade de } \\
\text { arrendamento e o } \\
\text { valor da HPR }\end{array}$ & $\begin{array}{c}\text { Subsídio/Poupança } \\
\text { necessário ao } \\
\text { arrendamento da HPR }\end{array}$ \\
\hline $1 \mathrm{SM}$ & $\mathrm{R} \$ 11.717$ & $46,4 \%$ & $\mathrm{R} \$ 13.543$ \\
\hline $2 \mathrm{SM}$ & $\mathrm{R} \$ 23.434$ & $92,8 \%$ & $\mathrm{R} \$ 1.826$ \\
\hline $3 \mathrm{SM}$ & $\mathrm{R} \$ 35.152$ & $139,2 \%$ & - \\
\hline $4 \mathrm{SM}$ & $\mathrm{R} \$ 40.000^{4 !}$ & $158,3 \%$ & - \\
\hline $5 \mathrm{SM}$ & $\mathrm{R} \$ 40.000$ & $158,3 \%$ & - \\
\hline
\end{tabular}

Valores base 2006.

\footnotetext{
${ }^{46}$ As taxas de seguro determinadas pela Caixa Econômica Federal para o Programa Carta de Crédito também serão usadas para os outros programas de financiamento e arrendamento habitacional, pois, como se tratam de operações com riscos semelhantes, para o mesmo público e a maioria também operada pela CEF, os valores tendem a ser semelhantes.
} 
Considerando um comprometimento máximo de renda mensal estimado em $20 \%$ para o arrendamento habitacional, somente as famílias com renda mensal bruta igual ou acima de 3SM teriam acesso ao arrendamento da HPR. Para a inclusão das faixas com renda abaixo de 3SM, seria necessário que estas famílias tivessem poupança acumulada e/ou subsídios adicionais do poder público e/ou oferta de habitações com preço abaixo do estabelecido para a HPR.

\subsubsection{Programa de Subsídio à Habitação - PSH}

O Programa de Subsídio à Habitação, voltado à população com renda até $3 \mathrm{SM}$, é estruturado de forma diferente dos outros programas. Nesse programa, os agentes financeiros, juntamente com os governos locais, participam de leilões de recursos para subsídios habitacionais. $\mathrm{O}$ programa estabelece fronteiras máximas nas quais as propostas devem se adequar, como o preço da habitação, taxa de juros, comprometimento de renda, prazo de amortização etc. As análises que serão desenvolvidas a seguir utilizarão estas fronteiras como referência.

TABELA 16 : CONDIČ̃̃ES DE FINANCIAMENTO DO PSH

\begin{tabular}{l|l}
\hline Correção Monetária e Taxa de Juros & TR + 6\% ao ano \\
\hline Limite de Comprometimento de Renda & $20 \%$ da renda bruta mensal \\
\hline Prazo Máximo & 72 meses \\
\hline Seguro de Morte e Invalidez Permanente & $\begin{array}{l}\text { Taxa mensal de 0,0974\% sobre o valor do } \\
\text { financiamento }\end{array}$ \\
\hline Seguro de Danos Físicos do Imóvel & $\begin{array}{l}\text { Taxa mensal de 0,025\% sobre o valor de } \\
\text { avaliação do imóvel }\end{array}$ \\
\hline Sistema de amortização & Sistema PRICE \\
\hline
\end{tabular}

Fonte: Ministério das Cidades (2006)

Utilizando estas condições de fronteira como referência, a capacidade de financiamento para aquisição da HPR para as faixas de renda estudadas está expressa na tabela a seguir.

\footnotetext{
${ }^{47}$ Limite máximo do preço da habitação no PAR.

${ }^{48} \mathrm{O}$ PSH é um programa de subsídios e não propriamente de financiamento, o financiamento caberá à instituição financeira ou aos governos locais, dentro dos limites estabelecidos pelo programa.

${ }^{49}$ No sistema Price, as parcelas são calculadas de maneira que o valor-base das parcelas é sempre o mesmo, variando somente com a inflação.
} 
TABELA 17 : ESTIMATIVA DA CAPACIDADE DE FINANCIAMENTO E NECESSIDADE DE SUBSÍDIOS, POR FAIXA DE RENDA, PARA AQUISIÇÃO DA HPR ATRAVÉS DO PSH.

\begin{tabular}{c|c|c|c}
\hline $\begin{array}{c}\text { Renda Bruta } \\
\text { Mensal Familiar }\end{array}$ & $\begin{array}{c}\text { Capacidade de } \\
\text { Financiamento junto ao } \\
\text { Agente Financeiro ou } \\
\text { Poder Público }\end{array}$ & $\begin{array}{c}\text { Relação entre } \\
\text { capacidade de } \\
\text { financiamento e o } \\
\text { valor da HPR }\end{array}$ & $\begin{array}{c}\text { Subsídio/Poupança } \\
\text { necessário para } \\
\text { aquisição da HPR }\end{array}$ \\
\hline 1SM & $\mathrm{R} \$ 3.610$ & $14,3 \%$ & $\mathrm{R} \$ 21.650$ \\
\hline $2 \mathrm{SM}$ & $\mathrm{R} \$ 7.602$ & $30,1 \%$ & $\mathrm{R} \$ 17.658$ \\
\hline $3 \mathrm{SM}$ & $\mathrm{R} \$ 11.595$ & $45,9 \%$ & $\mathrm{R} \$ 13.665$ \\
\hline
\end{tabular}

Valores base 2006.

Como o PSH somente subsidia até R\$ 4.500 para aquisição de habitações, a diferença entre este subsídio e a necessidade de subsídios ora apresentada teria de ser coberta pela poupança acumulada das famílias e/ou pelos governos locais. A significativa necessidade extra de recursos para complementação do valor da HPR mostra a importância da participação dos governos locais na complementação da capacidade de pagamento das famílias, o que é uma premissa básica deste programa.

\subsubsection{Programa Crédito Solidário}

O Programa Crédito Solidário acontece somente de forma associativa e é voltado às famílias com renda mensal até 3SM, aceitando também as famílias com renda mensal até 5SM, limitado a 35\% do grupo associativo. O limite máximo permitido de financiamento para aquisição de habitações pelo programa é de R $\$ 25.000$, oferecendo as seguintes condições para os financiamentos habitacionais, expressas na tabela a seguir.

TABELA 18 : CONDIÇÕES DE FINANCIAMENTO DO PROGRAMA CRÉDITO SOLIDÁRIO

\begin{tabular}{l|l}
\hline Correção Monetária e Taxa de Juros & $\begin{array}{l}\text { TR, reajuste mensal do saldo devedor e das } \\
\text { parcelas } \\
\text { Não há cobrança de juros }\end{array}$ \\
\hline Comprometimento de Renda & até $25 \%$ da renda bruta mensal \\
\hline Prazo Máximo de financiamento & 240 meses \\
\hline Contrapartida mínima & $5 \%$ do valor do investimento \\
\hline Taxa de abertura de crédito & R 120,00 \\
\hline Seguro de Morte e Invalidez Permanente & $\begin{array}{l}\text { Taxa mensal de } 0,0974 \% \text { sobre o valor do } \\
\text { financiamento }\end{array}$ \\
\hline Seguro de Danos Físicos do Imóvel & $\begin{array}{l}\text { Taxa mensal de } 0,025 \% \text { sobre o valor de } \\
\text { avaliação do imóvel }\end{array}$ \\
\hline Sistema de amortização & Sistema PRICE \\
\hline
\end{tabular}

Fonte: Caixa Econômica Federal (2006c). 
Utilizando estas condições de fronteira como referência, a capacidade de financiamento para aquisição da HPR pelas famílias nas faixas de renda estudadas será:

TABELA 19 : ESTIMATIVA DA CAPACIDADE DE FINANCIAMENTO E NECESSIDADE DE SUBSÍDIOS, POR FAIXA DE RENDA, PARA AQUISIÇÃO DA HPR ATRAVÉS DO PROGRAMA CRÉDITO SOLIDÁRIO

\begin{tabular}{c|c|c|c}
\hline $\begin{array}{c}\text { Renda Bruta } \\
\text { Mensal Familiar }\end{array}$ & $\begin{array}{c}\text { Capacidade de } \\
\text { Financiamento no } \\
\text { Programa }\end{array}$ & $\begin{array}{c}\text { Relação entre } \\
\text { capacidade de } \\
\text { financiamento e o } \\
\text { valor da HPR }\end{array}$ & $\begin{array}{c}\text { Subsídio/Poupança } \\
\text { necessários para aquisição } \\
\text { da HRP }\end{array}$ \\
\hline 1 SM & $\mathrm{R} \$ 14.575$ & $57,7 \%$ & $\mathrm{R} \$ 10.684$ \\
\hline $2 \mathrm{SM}$ & $\mathrm{R} \$ 25.000^{50}$ & $99,0 \%$ & $\mathrm{R} \$ 1.263^{51}$ \\
\hline $3 \mathrm{SM}$ & $\mathrm{R} \$ 25.000$ & $99,0 \%$ & $\mathrm{R} \$ 1.263$ \\
\hline $4 \mathrm{SM}$ & $\mathrm{R} \$ 25.000$ & $99,0 \%$ & $\mathrm{R} \$ 1.263$ \\
\hline $5 \mathrm{SM}$ & $\mathrm{R} \$ 25.000$ & $99,0 \%$ & $\mathrm{R} \$ 1.263$ \\
\hline
\end{tabular}

Valores base 2006.

Como o valor do salário mínimo terá reajustes com periodicidade anual e o saldo devedor e as parcelas do financiamento por meio do programa crédito solidário terão reajustes com periodicidade mensal, existirá uma perda mensal em virtude da inflação, por parte dos beneficiários.

O programa crédito solidário mostrou os melhores resultados relativos à capacidade de financiamento da população de baixa renda dentre os programas estudados, demandando os menores subsídios adicionais e/ou poupanças extras, além dos subsídios implícitos que os programas já oferecem. Isto decorre do longo prazo de amortização, juntamente com a inexistência da cobrança de juros. O gráfico a seguir representa o resumo da capacidade de tomar financiamentos habitacionais da população de baixa renda, juntamente com o valor dos subsídios diretos máximos que podem ser concedidos pelos programas de financiamento que os ofertam.

\footnotetext{
${ }^{50}$ Limite máximo para financiamento habitacional no Programa Crédito Solidário.

${ }^{51}$ Contrapartida mínima do beneficiário (de $5 \%$ do valor do imóvel).
} 
FIGURA 19: GRÁFICO DA CAPACIDADE DE TOMAR FINANCIAMENTOS HABITACIONAIS E SUBSÍDIOS DIRETOS DA POPULAÇÃO DE BAIXA RENDA, EM RELAÇÃO À HPR

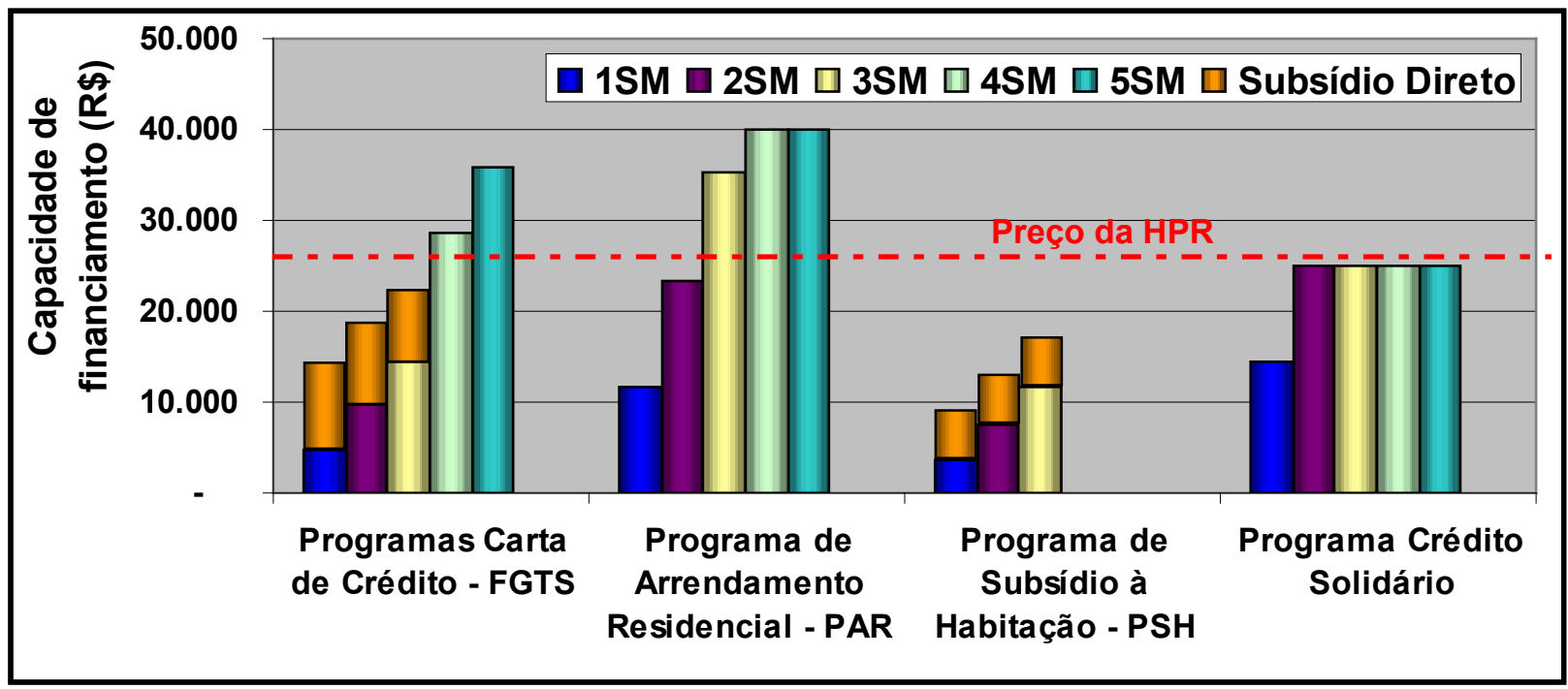

Valores base Maio/2006.

Pelo gráfico anterior e em relação a todos os programas estudados, para as famílias com renda até $3 \mathrm{SM}$, mostrou-se quase sempre necessário uma complementação da capacidade de pagamento, além dos subsídios diretos e indiretos já ofertados pelo Governo Federal, ou pelos fundos que este gerencia, tornando-se fundamental a participação, com contrapartida, dos governos locais para a complementação desta capacidade de pagamento, de forma a possibilitar o acesso dessa população à HPR, visto que, nesta faixa de renda, dificilmente a população conseguiria acumular poupança suficiente para este fim, ou formas para reduzir o preço da HPR aqui considerada, para caber dentro da capacidade de pagamento das famílias, como mutirões, autoconstrução etc. As famílias com renda a partir de 4SM conseguiriam financiar a HPR sem a necessidade de subsídios adicionais, tendo que arcar somente, fora o financiamento, com a contrapartida exigida pelos programas. 


\subsection{As exigências de crédito dos financiamentos habitacionais e a população de baixa renda}

A Caixa Econômica Federal é o agente operador e o maior agente financeiro dos programas federais de financiamento e arrendamento habitacionais voltados à população de baixa renda no Brasil, com exceção do PSH, que é operado pelo Ministério as Cidades e pela Secretaria do Tesouro Nacional. É do agente financeiro, que seleciona os mutuários e concede os financiamentos, o risco de inadimplência.

Segundo Granemann (2001), na busca de reduzir os crescentes números de inadimplência, a CEF modificou a forma de calcular a capacidade de crédito dos proponentes. Aonde era aplicado o percentual máximo de comprometimento de renda de forma linear sobre a renda bruta mensal das famílias, passou-se, então, a avaliar a capacidade de pagamento das famílias. Os interessados fornecem à CEF todas as informações referentes ao seu orçamento familiar para que esta possa fazer uma análise criteriosa de despesas e receitas ${ }^{52}$ de cada família, determinando assim a aprovação ou não do crédito e o tamanho deste. Nesta análise, são pedidas informações como os valores das contas mensais de energia, telefone, água e esgoto, condomínio e pensão alimentícia, juntamente com os compromissos financeiros já assumidos, como consórcios, crediários, planos de saúde, empréstimos, dentre outros. Assim, a CEF determina, dentro do orçamento familiar, os recursos que poderiam ser destinados ao pagamento de um financiamento/arrendamento habitacional, limitados pelo comprometimento máximo de renda determinado em cada programa.

$\mathrm{Na}$ análise desenvolvida no item anterior, foi considerado, para cada família, o limite máximo de comprometimento de renda. Na prática, a CEF faria uma análise da capacidade de pagamento, caso a caso, de cada família, o que poderia diminuir o valor de financiamento ou arrendamento possível, aumentando assim a necessidade de subsídios adicionais.

\footnotetext{
${ }^{52}$ A Caixa Econômica Federal já aceita proponentes não assalariados, que não têm carteira de trabalho assinada e que, portanto, não possuem contracheque, ou são profissionais liberais, ou fazem parte da crescente economia informal. Para isso é necessário comprovar a renda, apresentando documentos que possibilitem esta comprovação, como: faturas de cartão de crédito, comprovante de condomínio, aluguel e IPTU, pagamento da escola dos filhos, recolhimento de impostos etc.
} 


\subsection{A demanda reprimida para a aquisição de moradias adequadas e o número de famílias de baixa renda}

Para evitar confusão com o conceito de déficit habitacional, que durante muito tempo representou a necessidade de construção de novas moradias (com o conseqüente aumento do estoque), neste trabalho, deste ponto em diante, utilizar-se-á a expressão "demanda reprimida para a aquisição de moradias adequadas (DRAMA)" para representar o número de famílias existentes que necessitam trocar a moradia inadequada na qual atualmente moram por outra adequada. Esta utilizará o mesmo número de famílias que fazem parte do déficit habitacional calculado pela FJP (2005) e que, portanto, representará a soma das famílias que vivem em coabitação familiar (menos a família principal), em habitações rústicas e/ou que pagam ônus excessivo com aluguel, e que precisam de moradias adequadas, novas ou usadas, mas que não necessariamente virão do aumento do estoque de moradias, pois poderiam vir também do estoque de moradias vagas. O número do déficit habitacional será adotado pela inexistência de um número mais representativo da demanda pela aquisição de moradias adequadas no Brasil e que englobe, por exemplo, a provável migração de famílias de baixa renda que já vivem em moradias adequadas, próprias ou alugadas, mas que, caso existissem financiamentos adequados, buscariam a aquisição de moradias com melhores atributos de qualidade e/ou a moradia própria.

Em 2005, a DRAMA atingiu 7,98 milhões de famílias. Destas, 6,16 milhões correspondem às famílias de baixa renda. Comparando-se o crescimento da DRAMA da população de baixa renda entre os anos 2000 e 2005, verifica-se que, embora tenha existido um aumento absoluto desta, de cerca de $27 \%$, o aumento relativo ${ }^{53}$ manteve-se perto da estabilidade, diminuindo de $14,85 \%$ para $14,50 \%$, em relação ao número de famílias de baixa renda no mesmo período. $\mathrm{O}$ gráfico a seguir apresenta a variação absoluta da DRAMA para a população de baixa renda, entre 2000 e 2005, que aumentou para as famílias com renda até 3SM e diminuiu para aquelas com renda mensal de mais de $3 \mathrm{SM}$, como segue:

\footnotetext{
${ }^{53}$ Relação entre a DRAMA e o número total de famílias de baixa renda.
} 
FIGURA 20: GRÁFICO DA EVOLUÇÃO DA DRAMA ABSOLUTA DA POPULAÇÃO DE BAIXA RENDA, ENTRE 2000 E 2005

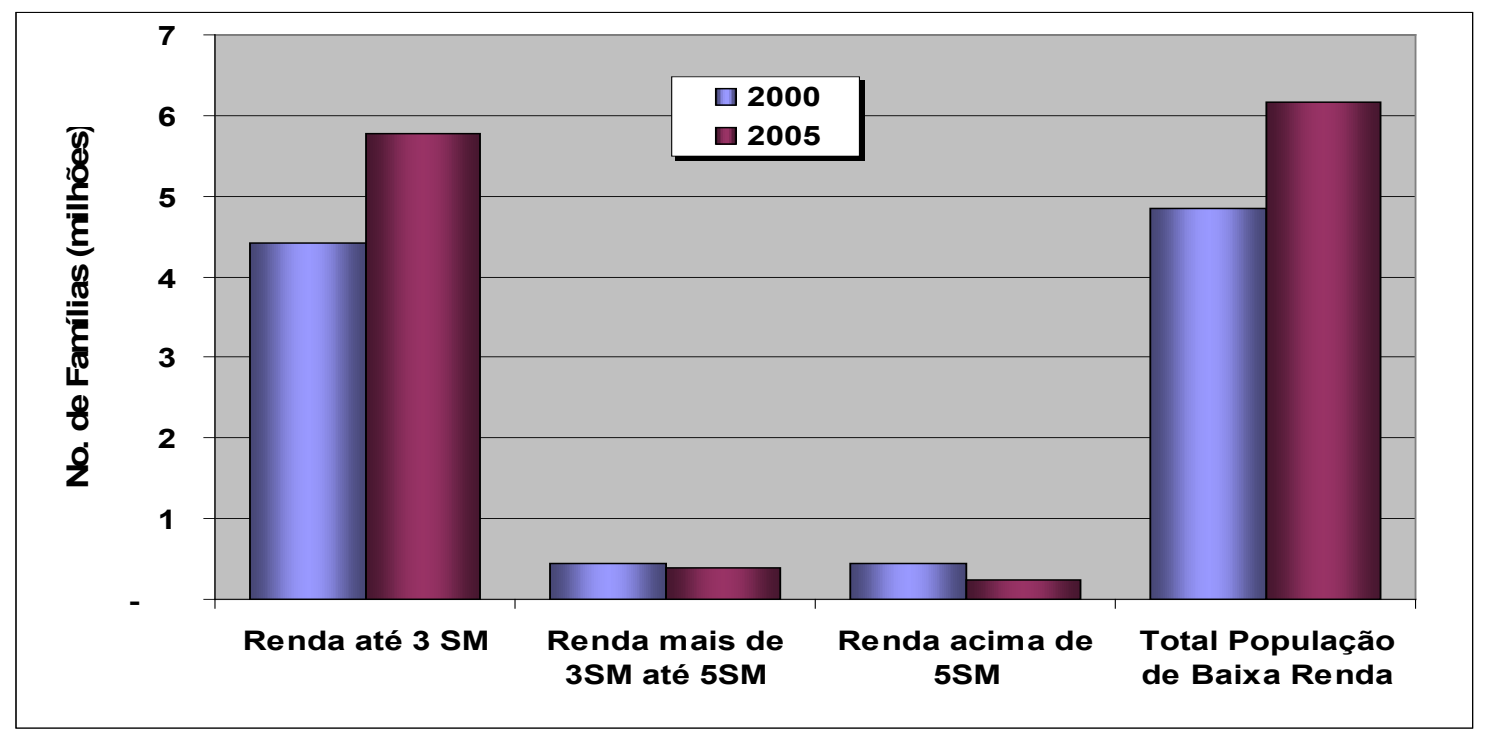

Fonte: Adaptado da Fundação João Pinheiro (2005).

O gráfico a seguir representa a variação relativa da DRAMA da população de baixa renda, entre 2000 e 2005, que diminuiu para todas as classes de renda estudadas, como segue:

FIGURA 21: GRÁFICO DA EVOLUÇÃO DA DRAMA RELATIVA DA POPULAÇÃO DE BAIXA RENDA, ENTRE 2000 E 2005

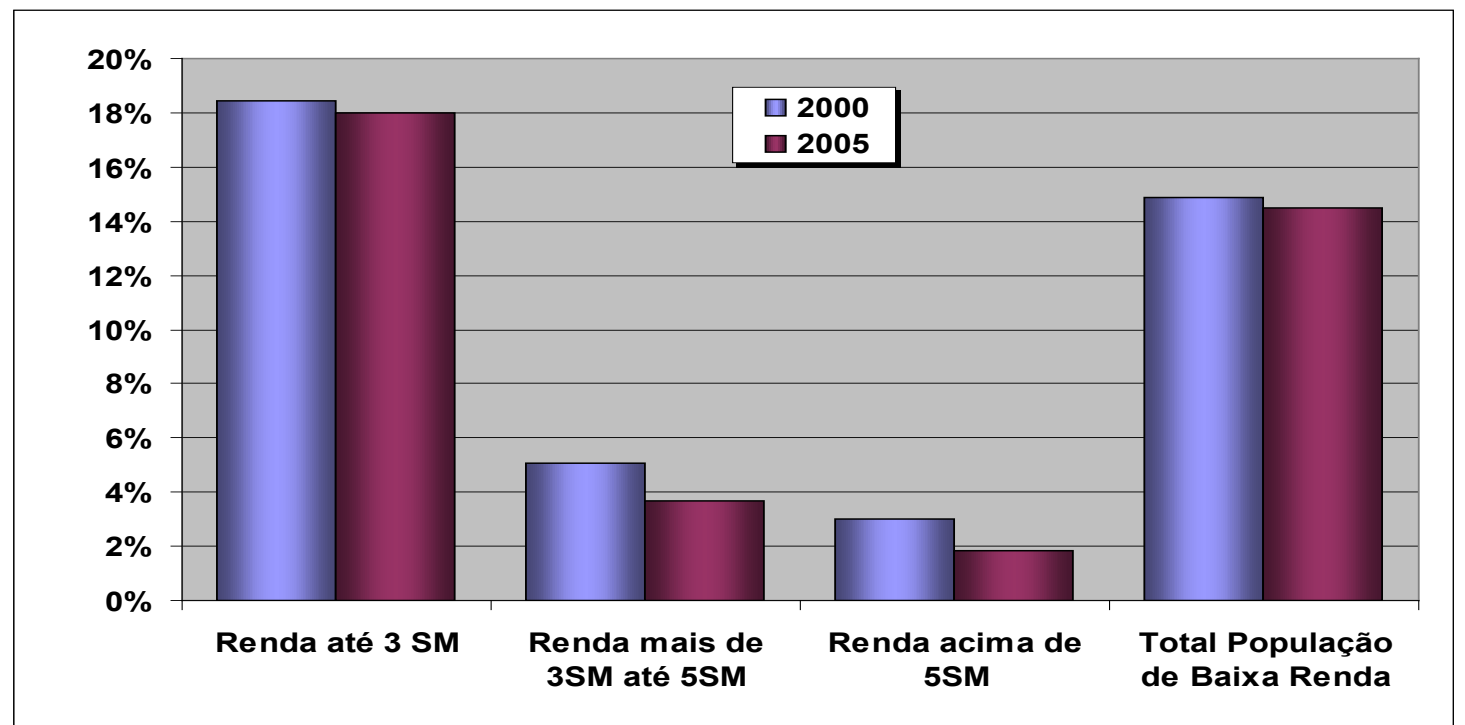

Fonte: Adaptado da Fundação João Pinheiro (2005) e IBGE - Pesquisa Nacional por Amostra de Domicílios (1995 a 2005). 
A Figura 20 permite observar que o problema habitacional assume dimensão mais crítica para as famílias com renda mensal até 3SM, que vêm apresentando crescimento absoluto da sua DRAMA, ao contrário das outras faixas de renda, sendo responsável pela maioria do crescimento da DRAMA no País.

No período entre 2000 e 2005, segundo a Fundação João Pinheiro (2000; 2005), a DRAMA do País cresceu em aproximadamente 1,36 milhão de famílias, para um crescimento do número total de famílias no País de cerca de 9 milhões. Neste mesmo período, o número total de domicílios passou de cerca de 45 para 53 milhões. Percebe-se que o crescimento do número de domicílios foi aproximadamente $11 \%$ menor que o crescimento do número de famílias. Já a DRAMA, aumentou em torno de 15\% em relação ao crescimento do número de famílias, concentrando-se, principalmente, nas famílias com renda mensal até 3SM. Isto demonstra um desalinhamento que pode estar tanto no acesso a financiamentos que possibilitem a aquisição de moradias adequadas quanto na oferta de moradias voltadas à população de baixa renda. Este desalinhamento que pode ser verificado também no aumento do número de domicílios vagos no País, que cresceu de 6,0 para 6,7 milhões, neste mesmo período.

\subsection{O volume de recursos utilizados e as famílias atendidas}

O Governo Federal tem feito esforços para ampliar os programas de financiamento habitacional voltados à população de baixa renda. No gráfico a seguir, pode-se ver a evolução dos recursos utilizados pelo Governo Federal para o financiamento/arrendamento habitacional da habitação popular, por intermédio dos programas Carta de Credito Individual, Carta de Crédito Associativa, Programa de Arrendamento Residencial - PAR $^{54}$ e Programa Crédito Solidário, como também a evolução dos recursos utilizados na concessão de subsídios diretos para complementação da capacidade de pagamento da população de baixa renda, por meio do Programa de Subsídio à Habitação - PSH e do Desconto (subsídio direto) do FGTS, criado pela Resolução 460/2004 do CCFGTS, como segue: 
FIGURA 22: GRÁFICO DA EVOLUÇÃO DOS RECURSOS FEDERAIS UTILIZADOS NO FINANCIAMENTO/ARRENDAMENTO E EM SUBSÍDIOS DIRETOS PARA HABITAÇÃO POPULAR

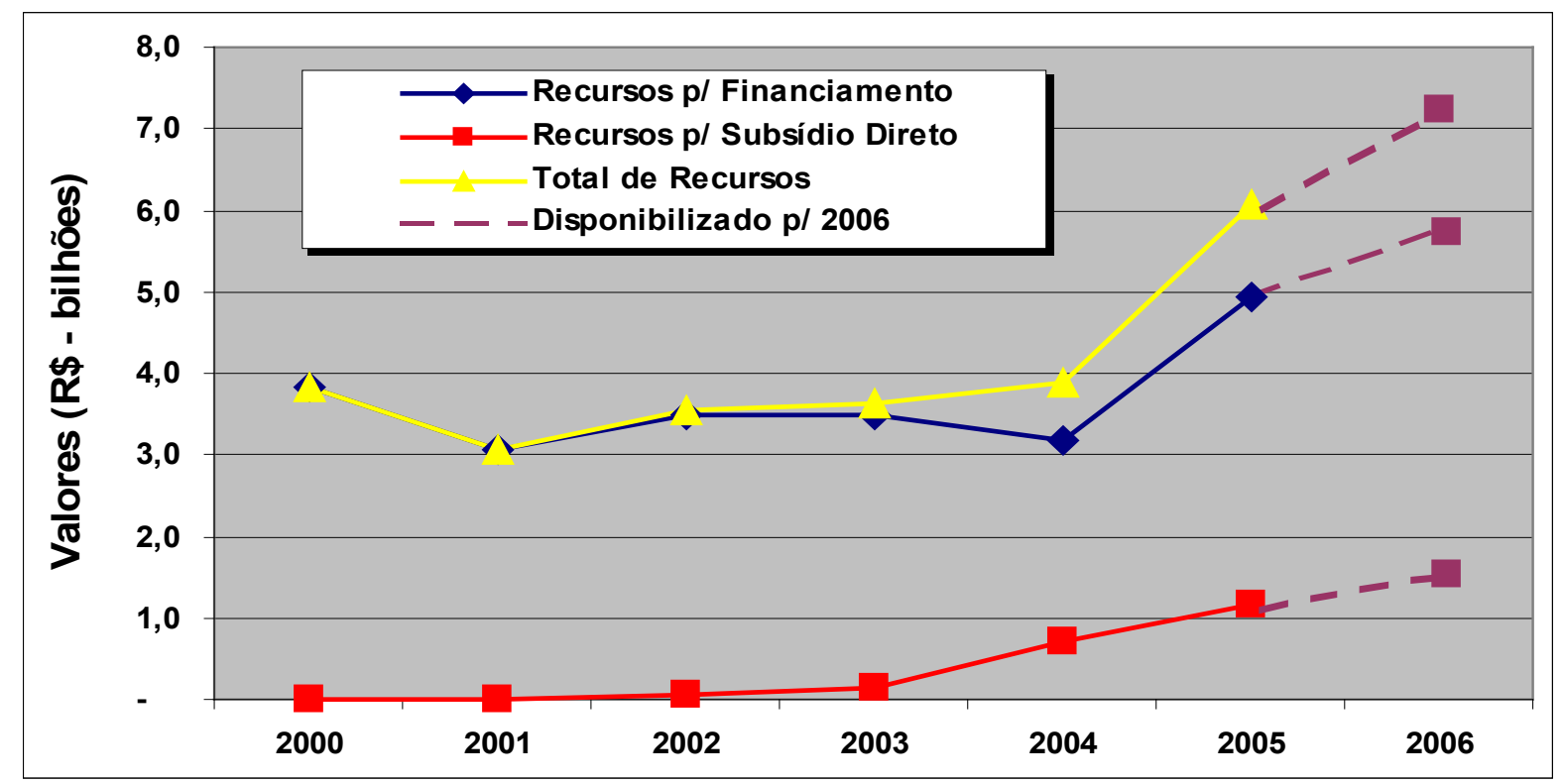

Fontes: Caixa Econômica Federal (2000, 2001, 2002a, 2003, 2004, 2005 e 2006).

Controladoria Geral da União (2002, 2003, 2004 e 2005).

Ministério das Cidades (2006).

(1) Valores em reais correntes.

(2) Os valores apresentados de 2000 a 2005 representam os recursos efetivamente utilizados, que ficaram abaixo dos recursos alocados para estes anos. Para 2006, o gráfico representa os recursos alocados, pois ainda não se tinha o resultado dos recursos utilizados neste ano.

Os recursos utilizados no financiamento/arrendamento da habitação popular mostraram uma recuperação em 2005, tendo aumentado aproximadamente do patamar de 3,8 bilhões em 2003 e 2004 para 6,0 bilhões em 2005, com a alocação de 7,2 bilhões para 2006. Foi visível, também, o crescimento dos recursos destinados ao subsídio direto para complementação da capacidade de pagamento da população de baixa renda, tendo aumentado aproximadamente de 140 milhões em 2003 para 1,16 bilhão em 2005.

O gráfico a seguir representa a evolução do número de unidades financiadas/arrendadas, com recursos do Governo Federal, para o financiamento da habitação popular no Brasil.

\footnotetext{
${ }^{54}$ Embora o PAR atenda famílias com renda mensal até 6SM, por não se ter informações que detalhem somente as famílias com renda até 5SM atendidas pelo programa, será considerada nas análises desenvolvidas a idéia de que todas as famílias atendidas pelo PAR são de baixa renda.
} 
FIGURA 23: GRÁFICO DO NÚMERO DE HABITAÇÕES POPULARES FINANCIADAS/ARRENDADAS COM RECURSOS FEDERAIS

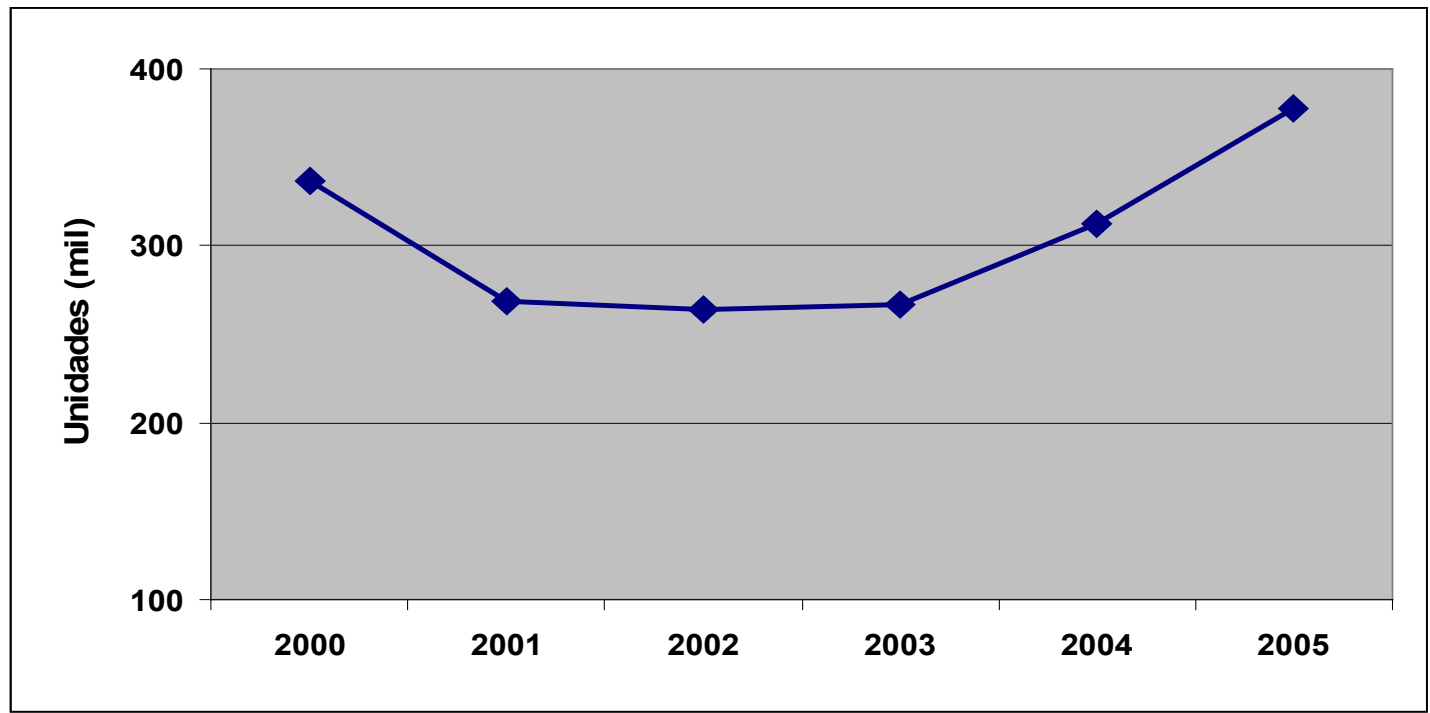

Fonte: Caixa Econômica Federal (2000, 2001, 2002a, 2003, 2004 e 2005).

O FGTS é a maior fonte de recursos para o financiamento habitacional da população de baixa renda no Brasil, mas também financia a população de média renda. Nos gráfícos apresentados, os financiamentos habitacionais feitos pelos programas Carta de Crédito Individual e Carta de Crédito Associativa, com recursos do FGTS, foram concedidos ao público-alvo do programa, classificado como habitação popular, ou seja, famílias com limite de renda mensal até $\mathrm{R} \$ 3.900^{55}$, aproximadamente $11 \mathrm{SM}$, acima do limite considerado como baixa renda neste trabalho, que é de 5SM.

Com relação à população de baixa renda, para o ano de 2005, segundo a Caixa Econômica Federal (2005), 79\% dos contratos firmados para os Programas Carta de Crédito foram destinados à população de baixa renda, totalizando aproximadamente 231 mil unidades. Somando-se a isso as unidades financiadas/arrendadas pelo PAR, pelo Programa Crédito Solidário e as unidades subsidiadas pelo PSH, chega-se a um total aproximado de 316 mil unidades financiadas/arrendadas para a população de baixa renda. Isto corresponde a cerca de $16 \%$ do crescimento médio anual do número de famílias de baixa renda entre 2000 e 2005 ou a 5\% da DRAMA das famílias de baixa renda.

O número de financiamentos concedidos para a população de baixa renda mostra um desempenho tímido do Governo Federal, que ainda está distante de atender o crescimento e contribuir significativamente para a redução da DRAMA desta população.

\footnotetext{
${ }^{55}$ Reais correntes.
} 


\subsection{Eficiência na utilização dos recursos alocados}

É inegável o aumento de recursos alocados para habitação popular em 2005 e 2006. Tão importante quanto o volume de recursos alocados, porém, é a medida em que estes recursos estão sendo efetivamente utilizados.

Os recursos alocados para o financiamento/arrendamento habitacional da habitação popular não têm sido utilizados em sua plenitude. O gráfico a seguir representa as parcelas dos recursos que foram efetivamente utilizados em relação aos recursos alocados.

FIGURA 24: GRÁFICO DAS PARCELAS UTILIZADAS DOS RECURSOS ALOCADOS PARA FINANCIAMENTO/ARRENDAMENTO DA HABITAÇÃO POPULAR, EM 2004 E 2005

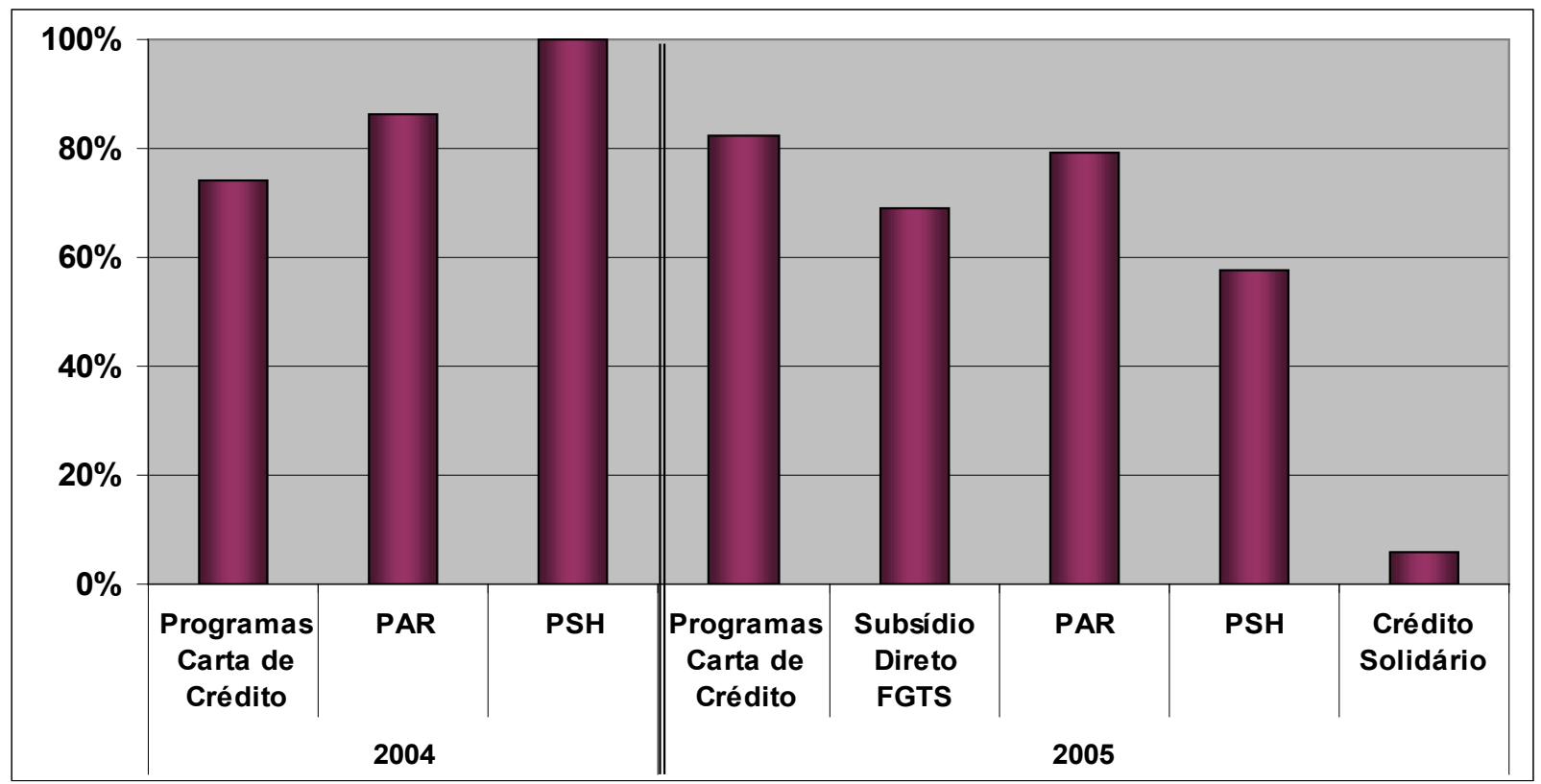

Fontes: Caixa Econômica Federal (2004 e 2005).

Controladoria Geral da União (2004 e 2005);

Ministério das Cidades (2005).

Isto representa que deixaram de ser utilizados perto de 1,0 bilhão de reais em 2004 e 2,1 bilhões em 2005. Para ilustrar, considerando-se o valor médio de financiamento/arrendamento da habitação popular em 2004 e 2005, deixaram de ser financiadas/arrendadas cerca de 77 mil habitações em 2004 e 124 mil em 2005.

Para Alves (2005), as principais razões para esta não-utilização de parte dos recursos alocados para o financiamento da habitação popular são: o acesso ao crédito, que continua difícil para as famílias, pela dificuldade de se adequarem aos requisitos exigidos pela CEF para contratar financiamentos, e a destinação dos recursos fundamentalmente a operações de pequeno valor, como financiamentos destinados à compra de material de construção e imóveis usados. 


\subsection{Distribuição dos recursos por região}

Como apresentado no Capítulo 3, a DRAMA tem discrepâncias regionais significativas, pois o Sudeste, de forma absoluta, e o Nordeste, de modo relativo, são as regiões com as maiores DRAMA's do País. O Governo Federal tem buscado distribuir os recursos disponíveis acompanhando o mapa da DRAMA, mediante o pré-direcionamento por região na alocação dos recursos. Pode-se ver pelo gráfico a seguir a distribuição percentual, por região, dos recursos do FGTS utilizados e da DRAMA da população de baixa renda.

FIGURA 25: GRÁFICO DA DISTRIBUIÇÃO DOS RECURSOS DO FGTS UTILIZADOS E DA DRAMA DAS FAMÍLIAS DE BAIXA RENDA, ENTRE 2003 E 2005, POR REGIÃO.

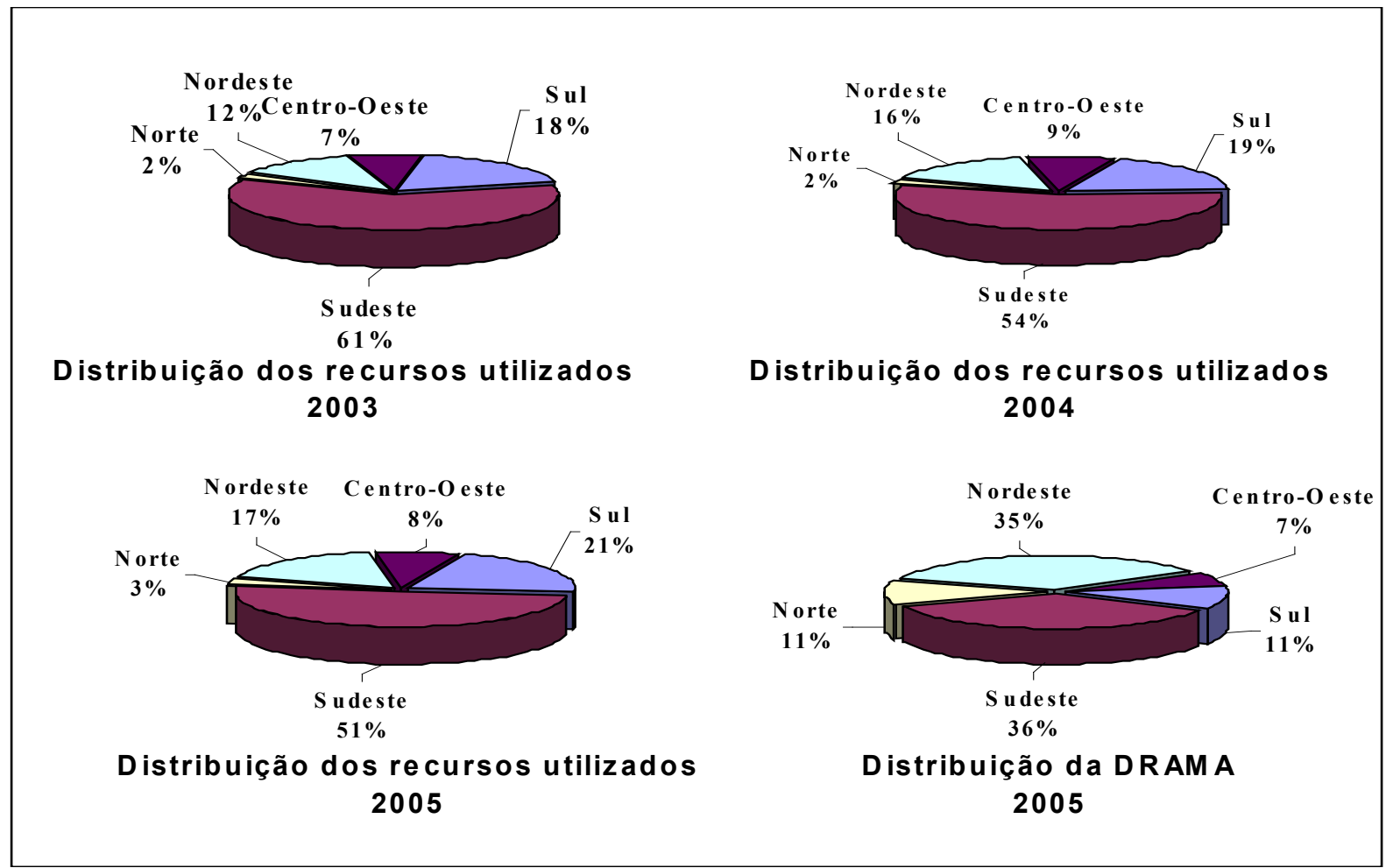

Fontes: Fundação João Pinheiro (2005)

Caixa Econômica Federal (2003, 2004 e 2005).

Pela Figura 25, e tomando-se o período entre 2003 e 2005 como referência, as regiões Sudeste, Sul e Centro-Oeste receberam quantidade maior de recursos, proporcionalmente ao percentual que estas detêm da DRAMA das famílias de baixa renda, enquanto as regiões Nordeste e Norte ficaram em posição inversa. Isto mostra que ainda há um desalinhamento na política do Governo Federal para distribuição de recursos do FGTS por regiões, FGTS que responde por mais de 95\% dos recursos controlados pelo Governo Federal destinados ao financiamento/arrendamento habitacional da população de baixa renda no Brasil. 


\subsection{Estimativa da necessidade de ampliação do volume de recursos ofertados pelo Governo Federal para atender a população de baixa renda}

Neste item será estimada a necessidade de aumento do volume de recursos ofertados pelo Governo Federal para o financiamento e subsídio habitacional, de forma a atender ao crescimento do número de famílias e a eliminar a DRAMA da população de baixa renda.

Como mencionado no item 5.3, a DRAMA da população de baixa renda tem crescido de forma absoluta, mas, de forma relativa, tem se mantido perto da estabilidade, entre 2000 e 2005. Isto indica que, em face do número de famílias atendidas neste período pelos programas federais de financiamento/arrendamento habitacional, a DRAMA tem crescido, em média, em proporção semelhante ao crescimento do número de famílias de baixa renda.

Outro ponto importante a ressaltar é a quantidade de unidades atendidas em relação ao crescimento do número de famílias de baixa renda no Brasil, que se verificou entre 2000 e 2005, e que atingiu o valor máximo em 2005, com o atendimento do correspondente a 15,2\% do crescimento do número de famílias de baixa renda, indicando que a maioria das novas famílias de baixa renda tem conseguido outras formas de acesso à habitação adequada, como autofinanciamento, autoconstrução, financiamento dos governos locais ou mesmo buscado o aluguel como alternativa, já que a maioria delas não se tornou parte da DRAMA. O gráfico a seguir apresenta o percentual correspondente ao número de famílias de baixa renda atendidas pelos programas de financiamento/arredamento federais em relação ao crescimento do número de famílias de baixa renda no Brasil.

FIGURA 26: GRÁFICO DA PARTICIPAÇÃO DOS PROGRAMAS FEDERAIS NO ATENDIMENTO AO CRESCIMENTO DO NÚMERO DE FAMÍLIAS DE BAIXA RENDA NO BRASIL.

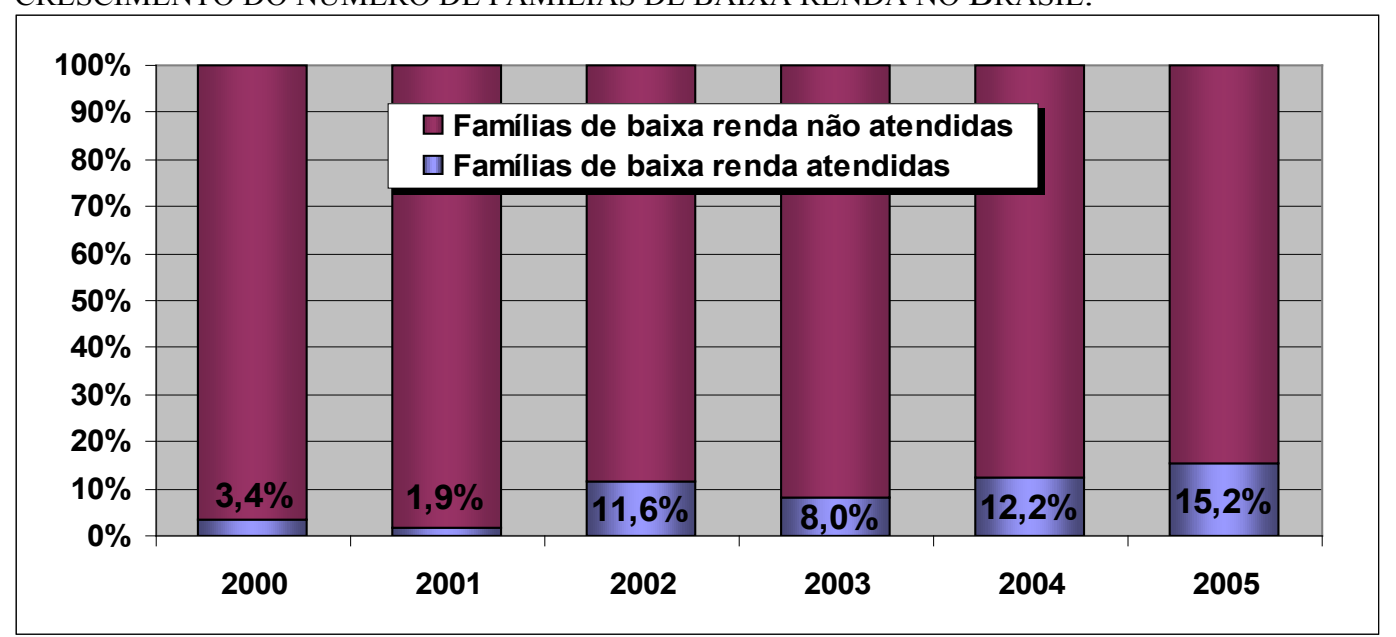

Fontes : Adaptado do IBGE - PNAD (1995 a 2005); Caixa Econômica Federal (2000, 2001, 2002a, 2003, 2004, 2005 e 2006d); e Braz (2005). 
No desenvolvimento da estimativa da necessidade de ampliação do volume de recursos ofertados pelo Governo Federal para atender à população de baixa renda, se faz necessário que se estabeleçam premissas que homogeneizem e simplifiquem os dados que alimentarão a análise, de forma a possibilitar sua execução com qualidade razoável, sem fazê-la cair em uma complexidade excessiva. É importante salientar, entretanto, que aqui não se tentará prever o futuro da realidade habitacional nos próximos anos, mas sim desenvolver uma hipótese de trabalho que, como resultado, apresente uma estimativa paramétrica da necessidade de aumento dos recursos federais para o financiamento e subsídio habitacional, de forma a absorver a parcela que não tem sido atendida do crescimento do número de famílias e a eliminar a DRAMA da população de baixa renda. Dentre estas premissas, as principais são:

- $\quad$ as condições sociais que influem na demanda por habitações em análise não se alterarão pelo período de dez anos tomados como referência;

- será considerada como referência principal a aquisição de habitações. Embora os programas de financiamento habitacional permitam outras modalidades de financiamento para o atendimento do crescente número de famílias e da DRAMA, como aquisição de lotes urbanizados, materiais de construção etc., estas soluções deixam por conta do beneficiário o financiamento do restante e não atendem por completo a demanda;

- $\quad$ será considerado como preço médio para aquisição de uma habitação adequada, o preço médio por metro quadrado, individual para cada região, do PAR. A habitação considerada será a menor habitação permitida pelo PAR, ou seja, uma habitação com área útil de $33 \mathrm{~m}^{2}$. O PAR foi escolhido como referência de preço por ser o único programa federal que estabelece área e especificações mínimas para as habitações, e seus empreendimentos são construídos normalmente em regime de empreitada, englobando todos os custos diretos e indiretos necessários para a construção de habitações; 
- caso existam financiamentos e recursos suficientes que possibilitem o acesso da população de baixa renda mediante a aquisição da habitação adequada, será considerado que, as novas famílias que entram no mercado habitacional e as famílias que fazem parte da DRAMA buscariam os financiamentos para aquisição de moradias adequadas; a oferta de habitações acompanharia o crescimento da demanda; e o preço médio por região da habitação considerada manter-se-ia constante, mesmo com o aumento da demanda;

- não será considerada a possível demanda oriunda das famílias que já vivem em habitações adequadas, e que, portanto, não fazem parte da DRAMA nem do crescimento do número de famílias de baixa renda;

- o crescimento do número de famílias de baixa renda mostrado nos PNAD's do IBGE será considerado como surgimento de novas famílias, que conseqüentemente necessitam de habitações adequadas, sendo desprezado o número de famílias que simplesmente tiveram sua renda mensal reduzida e, por esta razão, entraram na faixa de baixa renda, pela falta de informações que detalhem este fenômeno;

- $\quad$ a DRAMA no Brasil, quantificada pela Fundação João Pinheiro, é separada por faixas de renda somente para a população que vive em áreas urbanas. Portanto, neste trabalho, pela falta de informações relativas às áreas rurais, e pelo fato de a DRAMA urbana ser responsável por $81,1 \%$ da DRAMA total em 2005, será considerada como DRAMA da população de baixa renda a DRAMA urbana dessa população;

- a inadequação habitacional, embora parte das necessidades habitacionais da população de baixa renda como descrito no item 3.2, não será considerada como parte da DRAMA, por se tratar de um problema habitacional mais relacionado à carência de infra-estrutura, como saneamento básico, água e energia, do que ao financiamento à demanda por aquisição de moradias, de que trata este trabalho. 
Esta estimativa apresentará como resultado faixas de investimento que indicam a necessidade de ampliação do volume de recursos federais para o financiamento/arrendamento habitacional da população de baixa renda, ano a ano, para aquisição da menor habitação popular ${ }^{56}$. Estas faixas de investimento serão limitadas por duas fronteiras, que são: cenário I (fronteira inferior) - atendimento da parcela do crescimento anual do número de famílias de baixa renda necessária para evitar o crescimento absoluto da DRAMA; cenário II (fronteira superior) atendimento da parcela do crescimento descrita no item anterior, juntamente com a gradual eliminação da DRAMA em um horizonte de 10 anos.

A parcela do crescimento anual do número de famílias de baixa renda a ser atendida, de forma a evitar o crescimento absoluto da DRAMA, corresponderá a 23,7\%. Para isso, foi considerado o percentual das famílias de baixa renda atendidas com recursos do Governo Federal entre 2000 e 2005, somado ao percentual do crescimento da DRAMA no mesmo período, ambos em relação ao crescimento do número de famílias de baixa renda. Portanto, admite-se a hipótese de que os $76,3 \%$ restantes do crescimento do número de famílias de baixa renda conseguiriam se autofinanciar, procurariam a ajuda dos governos locais ou buscariam o aluguel, mantendo-se o mesmo comportamento constatado entre 2000 e 2005. Como não se tem informações sobre quantas famílias de baixa renda se autofinanciaram, quantas foram financiadas pelos governos locais ou mesmo quantas buscaram o aluguel como solução neste período, esta premissa de continuidade de comportamento será adotada para o desenvolvimento desta análise.

O ponto de partida para determinação das fronteiras ora descritas será a projeção do crescimento anual do número de famílias de baixa renda no Brasil, pelo período de 10 anos. $\mathrm{O}$ gráfico a seguir representa esta projeção, que foi feita mediante regressão linear entre a projeção do crescimento da população brasileira $^{57}$ e o número de famílias de baixa renda ${ }^{58}$, obtendo-se, assim, a tendência do crescimento do número de famílias de baixa renda no Brasil, de 2006 até 2015, como segue:

\footnotetext{
${ }^{56}$ A menor habitação popular será considerada nesta análise como a menor habitação adequada possível permitida pelo PAR.

${ }^{57}$ IBGE - tabela população projetada - 1980-2050. <www.ibge.gov.br>, acesso em 15 fev. 2007.

${ }^{58}$ IBGE - Pesquisa Nacional por Amostra de Domicílios (1995 a 2005).
} 
FIGURA 27: GRÁFICO DA PROJEÇÃO DO NÚMERO DE FAMÍLIAS DE BAIXA RENDA ATÉ 2015.

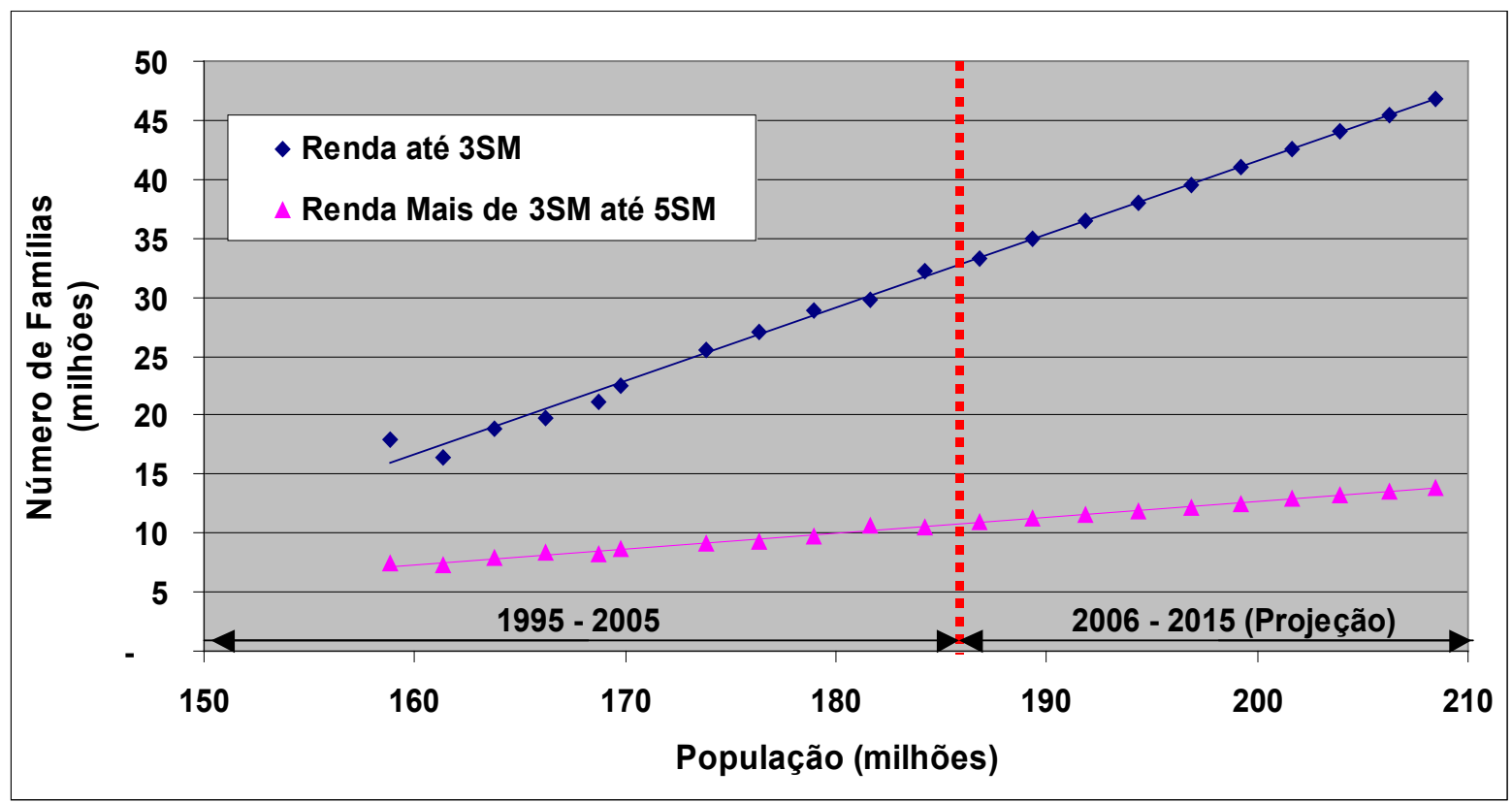

Os preços para aquisição da menor habitação popular, por região, utilizados neste estudo, terão como referência o $\mathrm{PAR}^{59}$, e englobam todos os custos diretos e indiretos de uma habitação popular. A tabela a seguir apresenta os preços das habitações a serem utilizadas, por região.

TABELA 20 : ESTIMATIVA DO PREÇO DA MENOR HABITAÇÃO POPULAR.

\begin{tabular}{c|c|c|c}
\hline Região & Preço Unitário & Área da Habitação & Preço da Habitação \\
\hline Norte & $\mathbf{R} \$ 680,00 / \mathrm{m}^{2}$ & $33 \mathrm{~m}^{2}$ & $\mathrm{R} \$ 22.440,00$ \\
\hline Nordeste & $\mathbf{R} \$ 650,00 / \mathrm{m}^{2}$ & $33 \mathrm{~m}^{2}$ & $\mathrm{R} \$ 21.450,00$ \\
\hline Sul & $\mathbf{R} \$ 810,00 / \mathrm{m}^{2}$ & $33 \mathrm{~m}^{2}$ & $\mathrm{R} \$ 26.730,00$ \\
\hline Sudeste & $\mathbf{R} \$ 850,00 / \mathrm{m}^{2}$ & $33 \mathrm{~m}^{2}$ & $\mathrm{R} \$ 28.050,00$ \\
\hline Centro-Oeste & $\mathbf{R} \$ 740,00 / \mathrm{m}^{2}$ & $33 \mathrm{~m}^{2}$ & $\mathbf{R} \$ 24.420,00$ \\
\hline
\end{tabular}

Valores base Maio/2006. Os valores das habitações referenciais foram trazidos para a base Maio/2006 utilizando-se o INCC como índice inflacionário, de forma a coincidir com o mês de reajuste anual do salário mínimo.

\footnotetext{
${ }^{59}$ A metodologia utilizada para a definição do preço médio por metro quadrado foi a tomada aleatória de 25 empreendimentos do PAR, cinco de cada região do País, que englobassem a compra do terreno, os custos de construção e a margem de lucro dos empreendedores. Calculou-se então o preço médio por metro quadrado de cada empreendimento e então a média aritmética dos cinco empreendimentos de cada região, obtendo-se assim o preço médio por metro quadrado estimativo de cada região. Os empreendimentos e seus valores foram conseguidos junto ao SINAPI - Sistema Nacional de Pesquisa de Custos e Índices da Construção Civil, disponível em: <www.caixa.gov.br>, acesso em: 15 jan. 2007, e em consultas à CEF.
} 
Discutir a real necessidade de recursos para atender à população de baixa renda no Brasil é uma questão complexa e polêmica. Como será demonstrado a seguir, dependendo da consideração do tamanho dos financiamentos a serem concedidos, os resultados variam acentuadamente.

Portanto, para o cálculo da necessidade de ampliação do volume de recursos federais para atender a população de baixa renda, serão consideradas duas hipóteses de trabalho, cada uma com uma consideração para o valor do financiamento: [i] - primeira hipótese - situação ideal, em que a parcela considerada do crescimento do número de famílias e a DRAMA da população de baixa renda serão atendidas pela aquisição da menor habitação popular; [ii] segunda hipótese - nesta, será considerado também o atendimento das famílias de baixa renda por financiamentos de parte da habitação (como lotes urbanizados, construção, materiais de construção etc.) e habitações usadas. $\mathrm{O}$ valor do financiamento considerado será então a média dos financiamentos concedidos em cada programa em 2005 e, para distribuição do número de financiamentos por programa, serão utilizados como referência os percentuais da cesta de financiamentos efetivamente concedidos em 2005.

\subsubsection{Primeira hipótese: atendimento da população de baixa renda pela aquisição da menor habitação popular}

Nesta hipótese, considera-se que o atendimento das famílias de baixa renda ocorrerá exclusivamente pela aquisição da menor habitação popular, que será representada pelos valores médios regionais de habitação representados na Tabela 20. O gráfico a seguir representa o volume de recursos necessários para atender a parcela considerada do crescimento e a eliminação do DRAMA. 
FIGURA 28: GRÁFICO DA PROJEÇÃO DO VOLUME ANUAL DE RECURSOS NECESSÁRIOS PARA ATENDER TANTO A PARCELA CONSIDERADA DO CRESCIMENTO QUANTO A DRAMA DAS FAMÍLIAS DE BAIXA RENDA, NA AQUISIÇÃO DA MENOR HABITAÇÃO POPULAR.

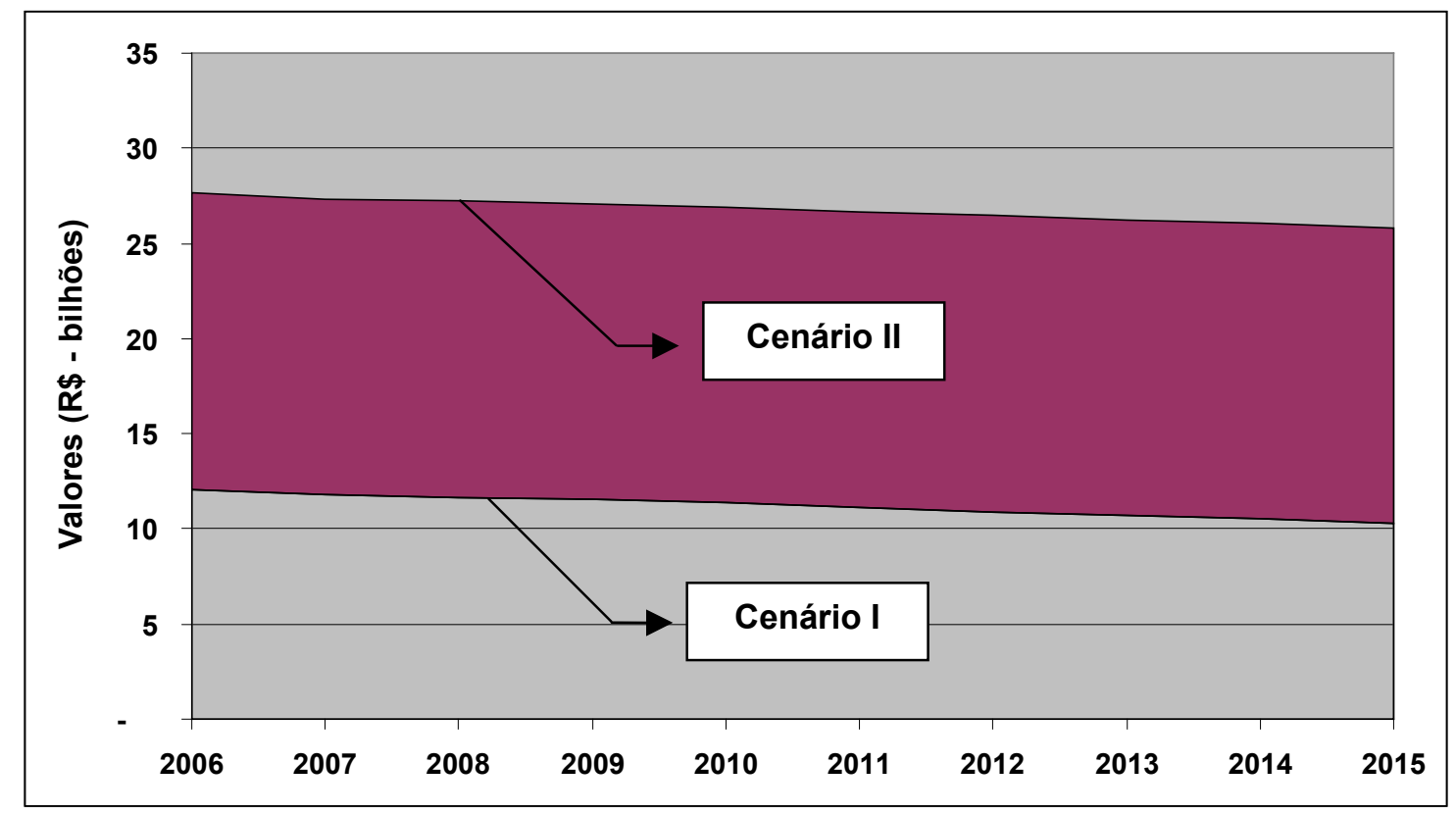

Valores base Maio/2006.

Embora a projeção do número de famílias de baixa renda mostre uma tendência de crescimento, como apresentado na Figura 27, a velocidade de crescimento do número de famílias mostrou uma tendência de queda para o período estudado. Isto resulta em um número menor de famílias a ser atendido todos os anos, o que ocasiona a necessidade decrescente por financiamentos habitacionais, mostrada no gráfico da Figura 28.

O resultado dessa simulação indica que a estimativa dos recursos necessários para atender a parcela considerada do crescimento e a DRAMA das famílias de baixa renda fica distante dos recursos alocados pelo Governo Federal para este fim. O Ministério das Cidades (2006), no seu Guia de Orientação de Programas Habitacionais, publicou o orçamento federal com os recursos alocados para o financiamento, arrendamento e subsídios diretos voltados à habitação popular para 2006, que, somados, totalizam 7,2 bilhões de reais. Isto corresponde a aproximadamente $26 \%$ da projeção total dos recursos necessários ao atendimento da parcela considerada do crescimento do número de famílias e a eliminação da DRAMA da população de baixa renda em um horizonte de 10 anos, pela aquisição da menor habitação popular, em 2006. 
Da estimativa de recursos necessários para atender as famílias de baixa renda, parte seria destinada ao financiamento habitacional e a outra parte teria de vir como subsídios ${ }^{60}$, de forma a complementar a capacidade de financiamento na aquisição da menor habitação popular. Utilizando-se os programas de financiamento descritos no Capítulo $4^{61}$, tem-se aproximadamente a seguinte composição para a separação dos recursos entre financiamentos habitacionais e subsídios (exclusive os subsídios implícitos já existentes):

FIGURA 29: GRÁFICO DA DISTRIBUIÇÃO, POR TIPO, DA PROJEÇÃO ANUAL DE RECURSOS NECESSÁRIOS PARA ATENDER TANTO A PARCELA CONSIDERADA DO CRESCIMENTO QUANTO A DRAMA DAS FAMÍLIAS DE BAIXA RENDA

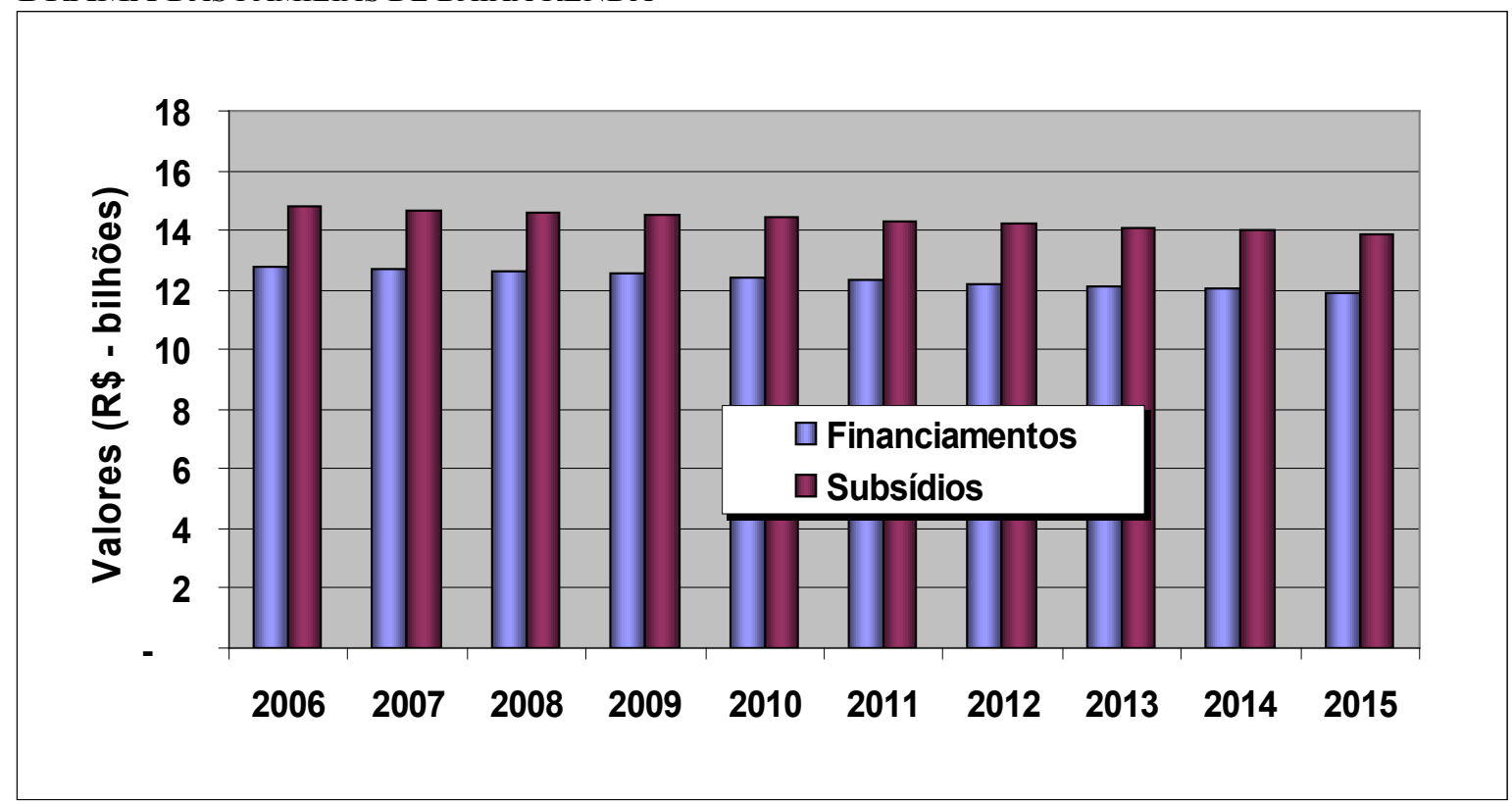

Valores base Maio/2006.

Os recursos que precisariam vir através de $\operatorname{subsídios}^{62}$, ou da poupança acumulada das famílias, seriam maiores do que os recursos vindos dos financiamentos habitacionais que as famílias de baixa renda poderiam conseguir, isto porque, na projeção do crescimento do número de famílias e na composição da DRAMA, existe maior número de famílias com renda mensal até 3SM, que necessitam de mais subsídios e/ou poupança acumulada do que os valores que podem contrair como financiamento habitacional, como visto no Capítulo 4. Outro fator importante, que contribuiu para este quadro, é que os Programas Cartas de Crédito

${ }^{60}$ A complementação da capacidade de financiamento das famílias também poderia ser feita por intermédio de suas poupanças acumuladas, como, por exemplo, a conta vinculada do FGTS, caso as famílias as tenham.

${ }^{61}$ Para distribuição do número de financiamentos necessários em cada programa de financiamento, foram utilizados como referência os percentuais da cesta de financiamentos efetivamente concedidos em 2005.

${ }^{62}$ Além dos subsídios implícitos já embutidos nos financiamentos. 
e PSH, responsáveis por mais de $90 \%$ dos financiamentos concedidos à população de baixa renda em 2005, são aqueles que mais restringem os limites de financiamento habitacional para a faixa de renda até $3 \mathrm{SM}$, em valores significativamente inferiores àqueles das habitações aqui consideradas.

Em 2006, segundo o Ministério das Cidades (2006), para os recursos alocados pelo Governo Federal para habitação popular, $80 \%$ seriam recursos voltados ao financiamento habitacional, onerosos ou não, enquanto $20 \%$ seriam para subsídios diretos voltados à população de baixa renda. Para a população de baixa renda, porém, como visto na Figura 29, estes percentuais não se adequariam, necessitando-se que os recursos voltados aos subsídios diretos fossem aumentados para aproximadamente $53 \%$ dos recursos alocados para esta população.

Analisando-se o gráfico a seguir, que mostra a projeção regional da necessidade de recursos para aquisição da menor habitação popular para a população de baixa renda, percebe-se que a região Sudeste apresentará as maiores necessidades, seguida das regiões Nordeste e Sul.

Figura 30: GRÁFICO DA DISTRIBUIÇÃO, POR REGIÃO, DA PROJEÇÃO DO VOLUME ANUAL DE RECURSOS NECESSÁRIOS PARA ATENDER TANTO A PARCELA CONSIDERADA DO CRESCIMENTO QUANTO A DRAMA DAS FAMÍLIAS DE BAIXA RENDA

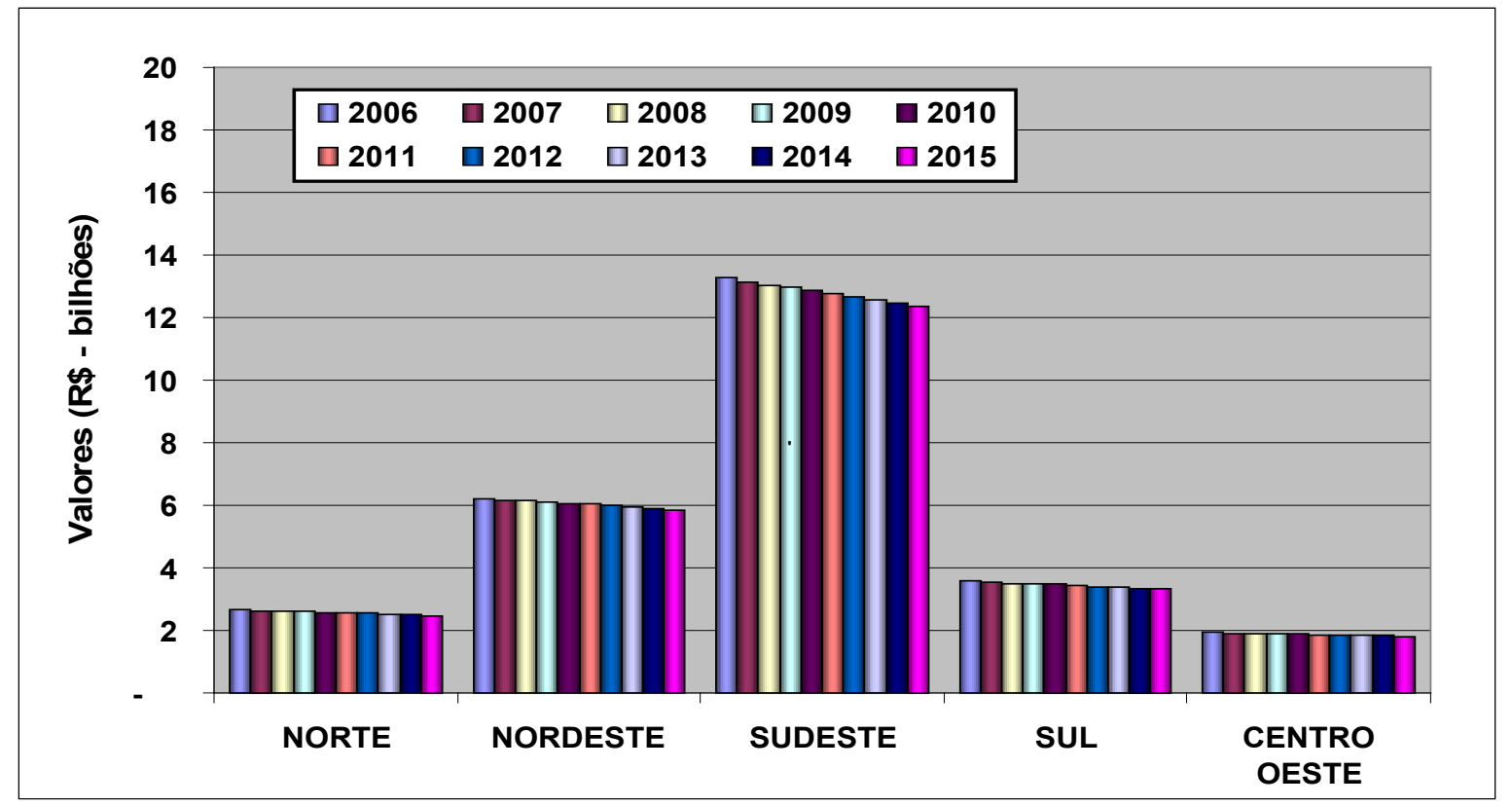

Valores base Maio/2006. 


\subsubsection{Segunda hipótese: atendimento da população de baixa renda pela aquisição de moradias e financiamentos parciais}

Os programas federais para financiamento habitacional oferecem várias modalidades de financiamentos além da aquisição de habitações novas, como aquisição de habitações usadas, compra de lotes urbanizados, materiais de construção, construção e conclusão de unidades habitacionais etc., sendo grande parte voltada para financiar partes das habitações ${ }^{63}$. As outras partes normalmente são autofinanciadas e/ou financiadas pelos governos locais. Para ilustrar e ampliar a discussão, a segunda hipótese de trabalho considera o atendimento dos mesmos grupos atendidos na primeira hipótese, como mostrado na Figura 28, porém, com o objetivo de considerar estas diversas formas de financiamento no cálculo, a estimativa da necessidade de ampliação do volume de recursos ofertados pelo Governo Federal para atender a população de baixa renda foi desenvolvida, desta vez, considerando a média ${ }^{64}$ dos financiamentos federais voltados à habitação popular efetivamente concedidos em 2005, como segue:

FIGURA 31: GRÁFICO DA PROJEÇÃO DO VOLUME ANUAL DE RECURSOS NECESSÁRIOS PARA ATENDER TANTO A PARCELA CONSIDERADA DO CRESCIMENTO QUANTO A DRAMA DA POPULAÇÃO DE BAIXA RENDA, COM BASE NO VALOR MÉDIO DOS FINANCIAMENTOS CONCEDIDOS EM 2005.

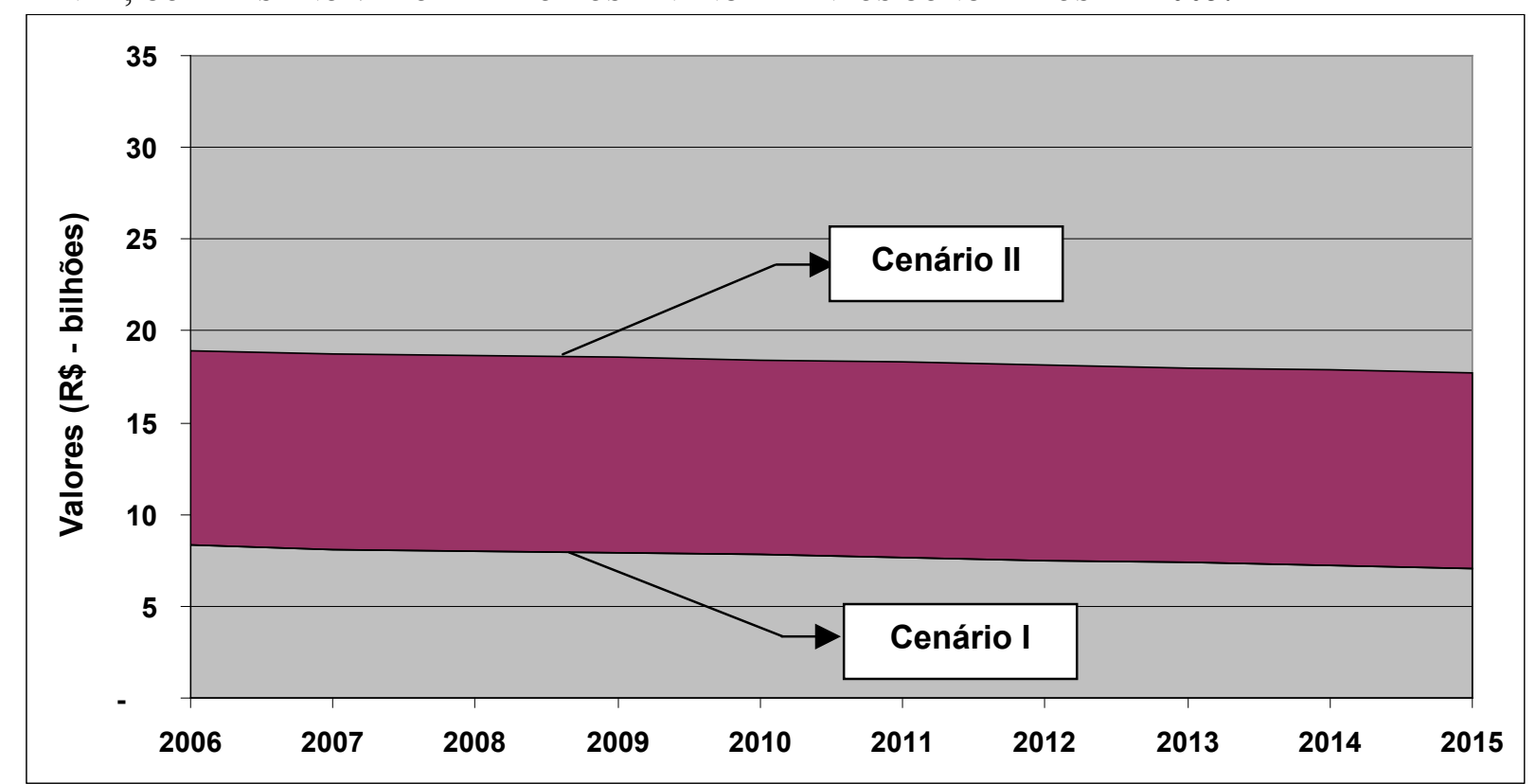

Valores base 2005 .

${ }^{63}$ Dos recursos do FGTS efetivamente utilizados no Programa Carta de Crédito Individual, maior programa para atendimento da habitação popular no País, aproximadamente $53 \%$ foram para o financiamento de cestas de materiais de construção, 31\% para aquisição de habitações usadas, $9 \%$ para construção ou aquisição de habitações novas e $7 \%$ para o restante (CAIXA ECONÔMICA FEDERAL, 2005).

${ }^{64} \mathrm{O}$ calculo da média dos financiamentos contemplou todos os tipos de financiamentos habitacionais concedidos para habitação popular, como aquisição de lotes urbanizados, habitações novas e usadas, material de construção, construção, reforma, ampliação etc. 
Mesmo considerando as médias dos financiamentos concedidos pelo Governo Federal em 2005, no lugar do preço da menor habitação popular, ainda assim, os recursos atualmente alocados são significativamente inferiores aos recursos necessários para atender à demanda da população de baixa renda. Por exemplo, os recursos alocados para este fim em 2006 correspondem aproximadamente a 38\% da necessidade projetada, para o atendimento da parcela considerada do crescimento e a DRAMA da população de baixa renda, demonstrando que a solução para a maioria desta população, mantendo-se este cenário, será em grande parte o autofinanciamento, a participação dos governos locais e/ou o aluguel de habitações. Com relação à primeira hipótese, no entanto, a necessidade de recursos neste caso foi aproximadamente $31,4 \%$ menor, em virtude da consideração de financiamentos parciais e da aquisição de habitações usadas, que resultam em valores de financiamento menores.

Das duas hipóteses estudadas, com diferentes considerações no valor dos financiamentos, a necessidade de recursos variou significativamente. Tomando-se como base os recursos alocados pelo Governo Federal em 2006 para habitação popular, o Governo Federal teria de ampliar este volume de recursos em aproximadamente em $283 \%$ para atender a população de baixa renda com a aquisição da menor habitação popular, e em 163\% para atendê-la também por financiamentos parciais. Se for considerada como objetivo somente a estabilização do valor absoluto da DRAMA, com sua conseqüente diminuição em termos relativos, estes números diminuiriam para $68 \%$ e $16 \%$, respectivamente. A ampliação dos recursos ofertados não necessariamente viria somente do aporte de dinheiro novo no sistema, pois parte poderia vir dos recursos que já estão aplicados no financiamento habitacional da população e voltarão a realimentar o sistema, o principal mais os juros cobrados.

$\mathrm{Na}$ análise da necessidade de ampliação do volume de recursos ofertados pelo Governo Federal para atender à população de baixa renda pela aquisição da moradia adequada, buscouse segmentar a parcela do crescimento desta população que tenderia a migrar para a DRAMA (caso não seja ampliada a oferta de recursos para o seu financiamento habitacional, tendo-se como referência o comportamento do setor entre 2000 e 2005) e a parcela dessas famílias que já faz parte da DRAMA. É importante, contudo, evidenciar que existe uma parcela dessa população que já vive em habitações adequadas, próprias ou alugadas, e uma parcela que vive em habitações com alguma forma de inadequação habitacional, e que, caso existam programas de financiamento habitacional que se adeqüem às suas capacidades de pagamento, poderiam querer adquirir outras moradias, buscando melhores atributos de qualidade ou 
simplesmente pela fuga do aluguel, por exemplo, e que aumentariam a demanda pela oferta de recursos para o financiamento habitacional para aquisição de moradias adequadas. Estas parcelas da população de baixa renda não foram consideradas na estimativa desenvolvida por, já estarem, de alguma forma, atendidas e não necessitarem adquirir outra moradia, embora possam decidir por fazê-lo, e, neste caso, poderiam vir a ser uma parcela significativa da demanda.

É importante ressaltar que problemas habitacionais dificilmente são solucionados por meio de uma única solução. Normalmente, são usadas diversas alternativas em conjunto, como um maior envolvimento dos governos locais, incentivo à poupança das famílias, mudanças nas políticas de regulamentação do setor, desenvolvimento de soluções para redução do preço da habitação, dentre outras.

A análise desenvolvida procurou estimar, à luz da estrutura dos programas de financiamento e subsídios atualmente ofertados para a população de baixa renda pelo Governo Federal, das necessidades desta população e do comportamento do setor entre 2000 e 2005, a necessidade de se aumentar o volume de recursos federais para absorver a parcela considerada do crescimento do número de famílias e eliminar a DRAMA da população de baixa renda em um horizonte de 10 anos, não se pretendendo afirmar que o simples aumento dos recursos federais seja a solução do problema habitacional da população de baixa renda, nem que a responsabilidade para a resolução deste problema seja somente do Governo Federal. 


\subsection{Considerações finais sobre a adequação dos programas federais de financiamento habitacional}

Quanto ao acesso da população de baixa renda aos financiamentos analisados, e tendo-se como base a aquisição da HPR, mostrou-se que nenhum dos programas atingiu todas as faixas de renda estudadas, existindo a necessidade de redução da diferença entre o preço da HPR considerada e a capacidade de financiamento das famílias, principalmente para aquelas com renda mensal até 3SM. Estas famílias ficam, então, dependendo de subsídios complementares, que podem vir dos governos locais, e/ou de formas de reduzir o valor da habitação referencial aqui considerada.

Um caminho para a redução do valor da habitação, relativamente à capacidade de pagamento da população de baixa renda, além dos ganhos de produtividade, é a redução dos impostos incidentes sobre a habitação popular, que é responsável por uma parcela significativa do seu preço. Segundo Souza (2006), a estimativa da incidência de impostos sobre habitação popular no Brasil é de aproximadamente $28 \%$ do seu valor, contra a carga tributária média de $11,5 \%$ do setor produtivo da economia brasileira e $25,5 \%$ do setor formal da construção como um todo.

Os programas federais de financiamento/arrendamento habitacional voltados à população de baixa renda no Brasil mostraram grande diversidade e sobreposição de objetivos e condições ofertadas, como: tipos de subsídios, público-alvo, definição do limite de comprometimento de renda, limite do financiamento, limite no preço da habitação, taxas de juros etc., funcionando de forma independente e diferente um do outro, embora em sua maioria busquem atender o mesmo público. Uma maior harmonização e especialização destes programas em faixas de renda específicas, principalmente para as faixas de renda até $3 \mathrm{SM}$, e um melhor nivelamento das condições demandadas para concessão dos financiamentos, poderiam trazer maior eficiência ao sistema no atendimento das necessidades habitacionais da população de baixa renda.

Os recursos efetivamente utilizados para financiamentos/arrendamentos habitacionais estão sendo inferiores aos recursos alocados para este fim, em um panorama de DRAMA crescente no País, principalmente para a população de baixa renda, é um indicativo de que a população de baixa renda está tendo dificuldades no acesso a estes recursos alocados pelos programas de financiamento oferecidos pelo Governo Federal. 
O Governo Federal, por sua vez, tem dividido os recursos alocados aos programas habitacionais por estados, tentando acompanhar a distribuição da DRAMA. Entretanto, dos recursos efetivamente utilizados, ainda não se tem conseguido atingir o nível ideal de distribuição, pois as regiões mais ricas, como Sudeste, Sul e Centro-Oeste, têm recebido mais recursos, proporcionalmente ao percentual que estas detêm da DRAMA total do País, em relação às regiões mais pobres - Norte e Nordeste.

Com a criação do PSH em 2002, o Governo Federal começou a mudar a estratégia de abordagem de como subsidiar a população de baixa renda, introduzindo no Brasil, pela primeira vez, o conceito de subsídios diretos, dados de uma vez no ato da concessão do financiamento, ao contrário do que vinha sendo praticado no País anteriormente, onde os subsídios eram unicamente implícitos, embutidos nos financiamentos. Em 2004, foi criado o Desconto do FGTS, pela resolução 460/2004 do CGFGTS, subsídio direto dado em conjunto com os financiamentos dos programas Carta de Crédito, aumentando-se substancialmente os recursos destinados a este fim. Os subsídios diretos são mais transparentes e fáceis de mensurar do que os indiretos, pois sabe-se, no momento da concessão, o exato impacto destes no orçamento governamental. Adicionalmente, estes são mais fáceis de serem percebidos pela população beneficiada, que passa a dar mais valor ao benefício recebido.

O número de famílias de baixa renda tem apresentado os maiores índices de crescimento em relação às outras faixas de renda. Como conseqüência disso, a DRAMA tem crescido majoritariamente neste segmento. A projeção do crescimento dessa população para os próximos anos indica que deverá se dar um tratamento diferenciado a esta população, de forma a evitar que a DRAMA tome proporções maiores. Em um primeiro momento, faz-se necessário parar com o crescimento da DRAMA, por meio do atendimento da parcela do crescimento desta população que não consegue o autofinanciamento e/ou que não consegue ser atendida pelos governos locais e pelo Governo Federal no acesso à habitação adequada, e em seguida, buscar evoluir para a eliminação da DRAMA.

Como dito anteriormente, discutir a real necessidade de recursos para atender à população de baixa renda no Brasil é uma questão complexa e polêmica, em virtude das diversas interpretações que podem existir relativas às parcelas da população que devem ser atendidas e ao valor dos financiamentos a considerar. 
Nos resultados encontrados para a necessidade de ampliação dos recursos federais para o financiamento/arrendamento e subsídio da população de baixa renda, verificou-se que, embora os recursos federais destinados a este fim tenham sido aumentados e mais bem direcionados nos últimos anos, estes ainda são insuficientes para atender ao crescimento do número de famílias e eliminar a DRAMA dessa população, precisando ser ampliados.

O FGTS, como principal fonte de recursos sustentáveis para o financiamento da população de baixa renda, tem limites determinados pelo número de pessoas empregadas no mercado formal e pelo valor médio dos salários. Em vista disso, dificilmente se conseguirá aumentar sua oferta de recursos nos níveis encontrados nas duas hipóteses consideradas. Portanto, fazse necessário que o Governo Federal envolva outros participantes que possam aumentar a oferta de recursos para esta faixa de renda, como, por exemplo: promover um maior envolvimento, com contrapartida, dos governos locais; promover e incentivar o aumento da participação do mercado no financiamento habitacional da população de menor renda, diminuindo a amplitude das faixas de renda que o Poder Público precisa atender; e incentivar o aumento da poupança de longo prazo, que possa ser utilizada no financiamento habitacional desta faixa de renda.

O Governo Federal está implantando o SNHIS - Sistema Nacional de Habitação de Interesse Social, que buscará promover maior envolvimento entre o Governo Federal e os governos locais, na busca de aumentar os recursos voltados ao financiamento e ao subsídio habitacional da população de baixa renda, dar mais eficiência aos programas de financiamento e promover a criação de um sistema de informação, monitoramento e avaliação dos programas e ações do setor habitacional, que tanta falta faz no desenvolvimento de pesquisas nessa área. Como o sistema ainda está em implantação, não se pode ainda verificar seus resultados, mas, provavelmente, esta maior integração entre os poderes públicos e maior disseminação da informação tende a trazer melhores resultados para a população de baixa renda. 


\section{CONCLUSÃO}

Como descrito por Hoek-Smit; Diamond (2003), a questão habitacional tem grande importância social e política para as sociedades. Ela é um fator importante na criação de estabilidade, saúde pública, justiça social e estímulo ao crescimento econômico.

No Brasil, ao longo dos anos, tem se tentado de diversas maneiras equacionar o problema habitacional, causado pelo rápido crescimento da população, juntamente com a grande migração para áreas urbanas. Este problema habitacional se concentra principalmente na população de baixa renda, que, por não ser capaz de pagar o preço de uma habitação adequada no mercado formal, migra para habitações subnormais, dando origem a favelas, cortiços, invasões etc. promovendo a degradação urbana nas regiões metropolitanas.

Para que a população de baixa renda tenha acesso à moradia adequada, é necessário que existam financiamentos e subsídios habitacionais que adeqüem sua capacidade de pagamento ao preço da habitação. Para isso, é necessário que existam programas de financiamento habitacional específicos para esta população, de forma a gerar a solvabilização da sua demanda.

A presente pesquisa analisou a adequação dos programas de financiamento habitacional para atender as necessidades de aquisição de moradias adequadas da população de baixa renda. Foi caracterizada por meio desta análise a capacidade de acesso da população de baixa renda a financiamentos habitacionais para aquisição de uma habitação adequada, a eficiência na utilização e distribuição dos recursos destinados a este fim e foi estimada a necessidade do aumento no volume de recursos pertencentes e gerenciados pelo Governo Federal e ofertados para atender a parcela considerada do crescimento e a DRAMA da população de baixa renda.

Os resultados da pesquisa mostraram inadequações dos programas federais de financiamento habitacional em relação ao financiamento da população de baixa renda, das quais as principais foram: os financiamentos que a população com renda até 3SM tem acesso, na maioria das vezes, não são suficientes para aquisição de uma habitação adequada; os recursos alocados para o financiamento habitacional desta população não têm sido utilizados em sua totalidade; a 
distribuição dos recursos não tem seguido a distribuição da DRAMA; e o volume de recursos ofertado pelos programas federais para o financiamento habitacional da população de baixa renda teria de ser aumentado significativamente para atender a parcela considerada do crescimento e para eliminar a DRAMA desta população.

O sistema de financiamento habitacional voltado à população de baixa renda no Brasil, tendo como fonte principal de recursos o FGTS, tem se mostrado ineficiente no atendimento das famílias com renda mensal até 3SM, que tem apresentado necessidades habitacionais crescentes. A maioria dos subsídios habitacionais ofertados tem sido de forma indireta, dados através de taxas de juros abaixo das de mercado. Este sistema tem sido utilizado desde a criação do SFH em 1964 até os dias atuais, sem ter apresentado impactos significativos na diminuição das necessidades habitacionais das famílias de baixa renda.

As principais limitações deste sistema têm sido: ciclos inconstantes de oferta de recursos para financiamentos habitacionais; recursos insuficientes para atender a demanda; regressividade social, onde os programas tem beneficiado majoritariamente as famílias com níveis de renda próximos aos limites superiores de renda impostos pelos programas; desincentivo à expansão e migração do mercado para atender as classes de menor renda; utilização de formas ineficientes de subsídios, não transparentes, pouco direcionados, difíceis de quantificar e de serem percebidos pelos beneficiários finais.

Conclui-se, portanto, que faz-se necessário uma reestruturação da política de subsídios utilizada no Brasil, de forma que esta incentive a participação do mercado no financiamento habitacional das classes de menor renda, atendendo pelo menos em parte as faixas de renda atendidas hoje somente pelos programas de financiamento federais, fazendo com que os subsídios ofertados sejam transparentes, direcionados, eqüitativos e de simples administração.

A utilização de subsídios diretos, voltados exclusivamente às famílias de baixa renda, parece ser a solução mais adequada à realidade brasileira, por cumprir os requisitos descritos no parágrafo anterior. A introdução no Brasil destes subsídios, através da criação do PSH em 2002 e da Resolução 460 do CCFGTS em 2004, já tem mostrado, no curto prazo compreendido entre 2004 
e 2006, resultados mais relevantes e direcionados às famílias de baixa renda do que foi visto na história do SFH.

Hoek-Smit; Diamond (2003) sugerem algumas análises que deveriam ser feitas antes da implementação de uma política de subsídios, as quais foram apresentadas no item 2.5 (p.19) deste trabalho, e que visam à detecção de inadequações nas regulamentações, na oferta de habitações e no acesso a financiamentos habitacionais, que, se resolvidas, ajudariam a diminuir a necessidade de subsídios. Para efeito de conclusão, e quanto ao acesso a financiamentos habitacionais, estas análises serão desenvolvidas a seguir com base nos resultados encontrados na pesquisa, como segue:

- a dificuldade de acesso a financiamentos habitacionais é a razão principal, porque parte da população não consegue adquirir ou reformar habitações - a dificuldade de acesso aos financiamentos habitacionais é uma das razões principais. Para as famílias com renda mensal até 3SM, que são a maioria da população brasileira e respondem pela maioria do crescimento populacional, a capacidade de financiamento é pequena em relação ao preço de uma habitação adequada. Isto força as famílias a buscarem o setor informal ou financiamentos parciais, que não atendem por completo sua necessidade, e que, provavelmente, é uma das causas da pequena quantidade de financiamentos para aquisição de habitações novas ou usadas, que responderam por somente $38 \%$ do número de financiamentos nos programas Carta de Crédito do FGTS em 2005, e pela não-utilização de todos os recursos alocados pelo Governo Federal para o financiamento habitacional da população de baixa renda;

- os problemas de acesso decorrem da existência de sistemas de monopólios públicos ou privados ou outras formas de falhas no sistema - o financiamento habitacional da população de baixa renda é ofertado majoritariamente com recursos pertencentes ou gerenciados pelo Poder Público. Com a utilização de fundos como o FGTS e o FDS, que oferecem taxas de juros bem abaixo das praticadas no mercado, ou mesmo financiamentos sem a cobrança de juros, esta parcela do mercado, com a estruturação que hoje está implantada, não é atrativa à iniciativa privada, caracterizando-se então como um monopólio público. O Poder Público, 
entretanto, tem tido dificuldades em ofertar recursos suficientes para o financiamento desta população;

- os problemas de acesso decorrem das condições macroeconômicas vigentes e não do sistema de financiamento em si - as condições macroeconômicas do País estão estáveis, com inflação controlada e crescimento do salário mínimo em termos reais nos últimos anos. Quanto aos juros de mercado, estes ainda estão em patamares elevados, enquanto a capacidade da população de baixa renda de pagar estes juros, ou uma parcela significativa destes, ainda está distante de acontecer, principalmente para a parcela da população com renda até 3SM. Em um primeiro momento, contudo, pode-se afirmar que os problemas de acesso a financiamentos habitacionais decorrem, principalmente, da baixa renda da população em relação ao preço de uma habitação adequada no setor formal e da inadequação dos programas de financiamento em relação às necessidades da população de baixa renda;

os fornecedores de crédito estão relutantes em entrar no mercado da população de baixa renda, porque não conseguem mensurar o custo e mitigar o risco de fornecer crédito para este mercado - o mercado não oferece financiamentos para esta população e se mostra relutante em fazê-lo. A falta de um sistema eficiente de informações que possa dar subsídios à tomada de decisões no setor, o custo de retomada da garantia no caso de inadimplência em relação ao valor de uma habitação popular, o risco de desvalorização da habitação popular como garantia do financiamento hipotecário devido a fatores de vizinhança como aumento da criminalidade e "favelização" do bairro, e o fluxo inconstante de renda dessas famílias, principalmente aquelas que fazem parte da economia informal, dificultam a mensuração do custo, a mitigação do risco e a validação de cenários que favoreçam a oferta de financiamentos hipotecários pelo mercado para esta faixa de renda. Por outro lado, o bom desempenho de outros setores da economia na oferta de microcréditos pessoais para a população de baixa renda, na venda de eletrodomésticos, mobiliário, etc., faz parecer que o microcrédito habitacional ofertado pelo mercado, embora mais caro e com prazos de pagamento mais curtos, possa ser utilizado na criação de empréstimos de pequeno valor ao consumidor para reforma, ampliação, construção, 
aquisição de materiais de construção etc., em complemento a subsídios diretos ofertados pelo Poder Público;

- existe a incerteza sobre os retornos futuros dos financiamentos, pois os riscos de inadimplência são muitos altos - existe uma vulnerabilidade maior da população de baixa renda para absorver variações macroeconômicas com impactos em financiamentos de longo prazo, e como descrito no item anterior, existe também uma fragilidade maior da habitação popular como garantia de financiamentos hipotecários, fazendo da inadimplência o maior risco do financiamento para esta faixa de renda. Caso o Poder Público não consiga disponibilizar informações que propiciem um melhor entendimento deste risco e/ou que encontre formas de absorver parte dele, dificilmente a iniciativa privada se interessará em oferecer financiamentos habitacionais para esta população. 


\section{REFERÊNCIAS}

ABIKO, A. K. Introdução à gestão habitacional. São Paulo: EPUSP, 1995. 31 p. Texto Técnico. Escola Politécnica, Departamento de Engenharia de Construção Civil. TT/PCC/12.

ALVES, M. H. A. F. Financiamento da política estadual de habitação de interesse social. Salvador: Fundação Escola de Administração, Universidade Federal da Bahia, 2006. 34 p. Nota técnica - relatório preliminar.

. Por dentro do financiamento habitacional para baixa renda. [Entrevista a Ana Maria Castelo e Maria Antonieta Del Tedesco Lins]. Conjuntura da Construção, São Paulo, v. 3, n. 3, p. 4-6, set. 2005 .

ARRETCHE, M. Intervenção do Estado e o setor privado: o modelo brasileiro de política habitacional. Revista Espaço \& Debates, n. 31, p. 21-36, 1990.

BRASIL. Controladoria Geral da União. Balanço-geral da união. Brasília: Controladoria geral da união, 2002. 4 v.

. Controladoria Geral da União. Balanço-geral da união. Brasília: Controladoria geral da união, 2003. 4 v.

. Controladoria Geral da União. Balanço-geral da união. Brasília: Controladoria geral da união, 2004. 4 v.

Controladoria Geral da União. Balanço-geral da união. Brasília: Controladoria geral da união, 2005. 5 v.

. Lei $n^{\circ} .8 .036$, de 11 de maio de 1990. Dispõe sobre o Fundo de Garantia do Tempo de Serviço, e dá outras providências. Brasília: Diário Oficial da União, 14 mai. 1990.

. Lei $n^{\circ} .9 .467$, de 10 de julho de 1997. Dá nova redação aos artigos $9^{\circ}$ da Lei no 8.036, de 11 de maio de 1990 e $2^{\circ}$ da Lei $n^{\circ} 8.844$, de 20 de janeiro de 1994. Brasília: Diário Oficial da União, 11 jul. 1997. 
. Lei $\mathrm{n}^{\circ}$. 10.208, de 23 de março de 2001. Acresce dispositivos à Lei no 5.859, de 11 de dezembro de 1972, que dispõe sobre a profissão de empregado doméstico, para facultar o acesso ao Fundo de Garantia do Tempo de Serviço - FGTS e ao seguro-desemprego. Brasília: Diário Oficial da União, 24 mar. 2001.

. Lei ${ }^{\circ}$. 11.124, de 16 de junho de 2005. Dispõe sobre o Sistema Nacional de Habitação de Interesse Social - SNHIS, cria o Fundo Nacional de Habitação de Interesse Social - FHHIS e institui o Conselho Gestor do FNHIS. Brasília: Diário Oficial da União, 17 jun. 2005.

BUCKLEY, R. M. Housing finance in developing countries. Washington, DC: St. Martin's Press, 1996. 208 p. World Bank, Urban Division.

CAIXA ECONÔMICA FEDERAL. Política, minuta de plano de lei e de exposição. Caixa Econômica Federal; Grupo de trabalho Caixa Econômica Federal, jun 2002 (b). 103 p. $2000.78 \mathrm{p}$.

FGTS - Relatório de gestão - exercício 2000. Brasília: Caixa Econômica Federal,

. FGTS - Relatório de gestão - exercício 2001. Brasília: Caixa Econômica Federal, 2001. $42 \mathrm{p}$.

FGTS - Relatório de gestão - exercício 2002. Brasília: Caixa Econômica Federal, 2002(a). $72 \mathrm{p}$. 2003. 50p

. FGTS - Relatório de gestão - exercício 2003. Brasília: Caixa Econômica Federal,

FGTS - Relatório de gestão - exercício 2004. Brasília: Caixa Econômica Federal, 2004. $133 \mathrm{p}$. 2005. $176 \mathrm{p}$.
FGTS - Relatório de gestão - exercício 2005. Brasília: Caixa Econômica Federal,

- Manual de fomento pessoa física - carta de crédito individual. Brasília: Caixa Econômica Federal, 2006(a). 63 p. 
. Manual de fomento pessoa jurídica. Brasília: Caixa Econômica Federal, 2006(b). 97 p.

$71 \mathrm{p}$.

. Manual do programa crédito solidário. Brasília: Caixa Econômica Federal, 2006(c).

. Execução orçamentária e perfil das contratações: recursos FGTS 2005. Brasília: Caixa Econômica Federal, 2006(d). Disponível em: <www.habitatbrasil.org.br>. Acesso em: 12 dez. 2006. (Apresentação).

CARVALHO, C. E.; PINHEIRO, M. M. S. FGTS: avaliação das propostas de reforma e extinção. Economia e Sociedade, Campinas, v. 15, p. 49-83, dez. 2000.

COELHO, W. R. O déficit das moradias: instrumento para avaliação e aplicação de programas habitacionais. 2002. 169 p. Dissertação (Mestrado) - Escola de Engenharia de São Carlos, Universidade de São Paulo, São Carlos, 2002.

CONSELHO CURADOR DO FUNDO DE GARANTIA DO TEMPO DE SERVIÇO. Resolução $\mathrm{n}^{\mathrm{o}}$. 460, de 14 de dezembro de 2004. Estabelece diretrizes para a aplicação dos recursos e a elaboração das propostas orçamentárias do FGTS, no período de 2005 a 2008. Brasília: Diário Oficial da União, 20 dez. 2004.

CONSELHO CURADOR DO FUNDO DE GARANTIA DO TEMPO DE SERVIÇO. Resolução $\mathrm{n}^{\mathrm{o}}$. 482, de 13 de setembro de 2005. Altera os valores de avaliação, de venda e de investimento a que se refere o subitem 5.1 do anexo II da Resolução $n^{\circ}$. 460, de 14 de dezembro de 2004, para as regiões metropolitanas dos estados de São Paulo e Rio de Janeiro e do Distrito Federal, e dá outras providências. Brasília: Diário Oficial da União, 19 set. 2005.

CONSELHO CURADOR DO FUNDO DE GARANTIA DO TEMPO DE SERVIÇO. Resolução $\mathrm{n}^{\circ}$. 501, de 29 de março de 2006. Estabelece os limites da renda mensal bruta das áreas de Habitação Popular e Habitação/Operações Especiais, de que tratam os subitens 3.1 e 3.2 do Anexo II da Resolução n ${ }^{\circ}$. 460, de 14 de dezembro de 2004. Brasília: Ratificada através do Diário Oficial da União, 13 abr. 2006.

BRAZ, E. C. A.. Financiamento do desenvolvimento urbano. Brasília: Caixa Econômica Federal, 2005. Disponível em: <www.seduh.df.gov.br>. Acesso em: 8 dez. 2006. (Apresentação para a Segunda Conferência da Cidade - Distrital). 
FERGUSON, B. Housing finance options for low and medium income families: analysis of the Latin America experience. Housing Finance International, v. 18, n. 3, p. 11-14, Mar. 2004.

FERREIRA, T. P. A concessão de subsídios por meio do sistema financeiro de habitação. 2004. 122 p. Dissertação (Mestrado) - Pontifícia Universidade Católica do Rio de Janeiro, Rio de Janeiro, 2004.

FUNDAÇÃO JOÃO PINHEIRO. Déficit habitacional no Brasil 2000.. Belo Horizonte: Fundação João Pinheiro, 2000. 203 p. [Projeto PNUD-BRA-00/019 - Habitar-Brasil - BID].

. Déficit habitacional no Brasil 2005.. Belo Horizonte: Fundação João Pinheiro, 2005. 200 p. [Projeto PNUD-BRA-00/019 - Habitar-Brasil - BID].

GOMES, E. P. P. A Política habitacional brasileira e a expectativa de produtividade do capital na produção de unidades habitacionais. 1993. 94 p. Dissertação (Mestrado) - Escola Politécnica, Universidade de São Paulo, São Paulo, 1993.

GRANEMANN, R. O. Inadimplência na área de habitação da Caixa Econômica Federal, no âmbito do escritório de negócios institucional de Florianópolis: um estudo de caso. 2001. 165 p. Dissertação (Mestrado) - Universidade Federal de Santa Catarina, Florianópolis, 2001.

GRIMES JR, O. F., Housing for low income urban families. Washington, DC: World Bank, 1976. $159 \mathrm{p}$.

HOEK-SMIT, M.; DIAMOND, D. B. Subsidies for housing finance. Housing Finance International, v. 17, n. 3, p. 3-13, Mar. 2003.

INSTITUTO BRASILEIRO DE GEOGRAFIA E ESTATÍSTICA. Pesquisa nacional por amostra de domicílios: síntese de indicadores 2005. Rio de Janeiro: IBGE, 2005. Disponível em: <www.ibge.gov.br>. Acesso em: 15 jan. 2007.

INSTITUTO BRASILEIRO DE GEOGRAFIA E ESTATÍSTICA. Pesquisa de orçamentos familiares 2002/2003. Rio de Janeiro: IBGE, 2003. Disponível em: <www.ibge.gov.br>. Acesso em: 15 ago. 2006. 
INSTITUTO BRASILEIRO DE GEOGRAFIA E ESTATÍSTICA. Pesquisa de orçamentos familiares 1995/1996. Rio de Janeiro: IBGE, 1996. Disponível em: <www.ibge.gov.br>. Acesso em: 15 ago. 2006.

JORDAN, R. Financing urban and housing development in Latin America and the Caribbean. Housing Finance International, v.18, n.3, p. 3-10, Mar. 2004.

KAMPEL, L. C.; VALLE; M. T. M. Sistema financeiro da habitação. Rio de Janeiro: Instituto Brasileiro de Mercado de Capitais, 1974. 207 p.

KOHARA, L. T.; ANDRÉA; P. Rendimentos obtidos na locação e sublocação de cortiços Estudo de casos na área central da cidade de São Paulo. São Paulo: EPUSP, 1999. 10 p. Boletim Técnico. Escola Politécnica da USP, Departamento de Engenharia de Construção Civil. $\mathrm{BT} / \mathrm{PCC} / 243$.

KÖHLER, M. A. Financiamento habitacional. Brasília: Consultoria legislativa do Senado Federal; Coordenação de estudos, 2005. 36 p. (Texto para discussão, 29).

LORENZETTI, M. S. B. A questão habitacional no Brasil. Brasília: Câmara dos deputados; Consultoria legislativa da área XIII, Desenvolvimento urbano, trânsito e transportes, Jul 2001. 25 p. (Estudo).

MALPEZZI, S.; MAYO, S.; GROSS, D. Housing demand in developing countries. Washington, DC: World Bank, 1985. 109 p. (World Bank Staff Working Paper, 733).

MINISTÉRIO DAS CIDADES. Política nacional de habitação. Brasília: Governo Federal, Secretaria Nacional de Habitação, 2004. 86 p.

Programas habitacionais : guia de orientação - 2005. Brasília: Secretaria Nacional de Habitação, 2005. 59 p.

Programas habitacionais : guia de orientação - 2006. Brasília: Secretaria Nacional de

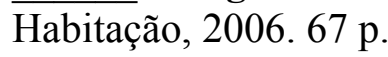

OLIVEIRA, M. C. B. S. Política de habitação popular no Brasil: passado e presente. 2000. 170 p. Dissertação (Mestrado) - Instituto de Pesquisa e Planejamento Urbano e Regional, Universidade Federal do Rio de Janeiro, Rio de Janeiro, 2000. 
SANDES, E.; MARTINS, S. Habitação, urbanismo e desenvolvimento local. 2004. 16 p. Disponível em: < http://www.sindimoveisms.com.br/asspedag.php>. Acesso em: 07 jun. 2006.

SANTOS, C. H. M. Políticas federais de habitação no Brasil : 1964/1998. Brasília: IPEA, 1999. 30 p. (Texto para discussão, n. 654).

SINDICATO DA INDÚSTRIA DA CONSTRUÇÃO CIVIL DO ESTADO DE SÃO PAULO; FUNDAÇÃO GETÚLIO VARGAS. Tabela de investimentos em habitação popular, saneamento e infra-estrutura urbana. Conjuntura da construção, São Paulo, v. 4, n. 4, p. 25, dez. 2006.

SOUZA, R. C. O peso dos impostos na habitação de interesse social. Conjuntura da Construção, São Paulo, v. 4, n. 3, p. 13-14, set. 2006.

TRIANA, A. F. Habitação popular no Brasil: análise do modelo operacional de financiamento pelas agências oficiais. 2006. 153 p. Dissertação (Mestrado) - Faculdade de Arquitetura e Urbanismo, Universidade de Brasília, Brasília, 2006.

VASCONCELOS, J. R.; CÂNDIDO JÚNIOR, J. O. O problema habitacional no Brasil : déficit, financiamento e perspectivas. Brasília: IPEA, 1996. 43 p. (Texto para discussão, n. 410).

WORLD BANK. Housing enabling markets to work. Washington, DC: World Bank International Bank for Reconstruction and Development, 1993. 159 p. (Policy Paper, ISSN 10148124).

WORLD BANK. Brazil - progressive low-income housing: alternatives for the poor. Washington, DC: World Bank - Finance, Private Sector and Infrastructure Management Unit, 2002. 81 p. (Report, n. 22032 BR). 


\section{REFERÊNCIAS COMPLEMENTARES}

ANSAH, S. B. Developing housing finance in transitional economies: Selected African countries outside of South Africa. Housing Finance International, v. 14, n. 2, p. 3-14, Dec. 1999.

ARRIETA, G. M. G. Access to housing and direct subsidies: lessons from Latin America Experiences. Housing Finance International, v. 13, n. 1, p. 43-53, Sep. 1998.

Mortgage loans and access to housing for low-income households in Latin America. Cepal Review, Lima, Peru, n. 85, p. 111-123, Apr. 2005.

AZEVEDO, S. Desafios da política federal de habitação popular no Brasil. Brasília: Secretaria Especial de Desenvolvimento Urbano da Presidência da República, 2002. 27 p. Artigo preparado para o Programa Habitar Brasil - BID.

BRIDGING the housing gap in emerging markets: A report from the overseas private investment corporation. Housing Finance International, v. 15, n. 2, p. 3-14, Dec. 2000.

BUCKLEY, R. M. Housing finance in developing countries: a transaction cost approach. Washington, DC: World Bank, 1989. 34 p. (Working paper, 347).

BUCKLEY , R. M.; MAYO, S. Housing policy in developing economies: evaluating the macroeconomics impacts. Washington, DC: World Bank, 1988. 30 p. (Discussion paper, Report INU 19).

CARDOSO, A. L. C. Política habitacional no Brasil : balanço e perspectivas. Rio de Janeiro: IPPUR/UFRJ. (s/d). $11 \mathrm{p}$.

CARNEIRO, D. D.; VALPASSOS, M. V. F. Financiamentos à habitação e instabilidade econômica: experiências passadas, desafios e propostas para a ação futura. Rio de Janeiro: FGV, 2003. 199 p.

CASTElO, A. M.; LINS, M. A. D. T. Por dentro do financiamento habitacional para baixa renda. Conjuntura da Construção. São Paulo, v. 3, n. 3, p. 4-6, set. 2005. 
CASTRO, P. F.; MAGAlHÃES, L. C. G. Recebimento e dispêndio das famílias brasileiras: evidências recentes da pesquisa de orçamentos familiares (POF) -1995/1996. Brasília: IPEA, 1998. 45 p. (Texto para discussão, n. 614).

COSTA, E. B. L. C. Financiamentos habitacionais existentes. Brasília: Câmara dos Deputados; Consultoria Legislativa, mar. 2003. 18 p. (Estudo).

FERGUSON, B. Micro-finance of housing: a key to housing the low or moderate-income majority?. Environment and Urbanization, v. 11, n. 1, p. 185-199, Apr. 1999.

GARCIA, F.; CASTELO, A. M.; PEDROZO, E.. Desenvolvimento habitacional e políticas públicas. Conjuntura da Construção. São Paulo, v. 4, n. 4, p. 4-9, dez. 2006.

GARCIA, F.; CASTELO, A. M. O déficit habitacional cresce apesar da ampliação do crédito. Conjuntura da Construção. São Paulo, v. 4, n. 1, p. 8-11, mar. 2006.

GONÇALVES, R. R. Aspectos da demanda por unidades habitacionais nas regiões metropolitanas - 1995/2000. Rio de Janeiro: IPEA, 1997. 22 p. (Texto para discussão, n. 514).

. O Déficit habitacional brasileiro: um mapeamento por unidades da federação e por níveis de renda domiciliar. Rio de Janeiro: IPEA, 1998. 21 p. (Texto para discussão, n. 559).

LEA, M. Attracting private capital into low-income markets. Housing Finance International, v. 20, n. 1, p. 7-19, Set. 2005.

LOZANO, V. The current situation and future outlook for housing finance in Latin America. Housing Finance International, v. 14, n. 2, p. 44-49, Dez. 1999.

MASSENA. R. M. R. O tema habitação na pesquisa nacional por amostra de domicílios (PNAD). Brasília: IPEA, 2002. 12 p. (Texto para discussão, n. 895).

MAYO, S. K. Subsidies in housing. Washington, DC: Inter-American Development Bank, 1999. $46 \mathrm{p}$.

MORAIS, M. P. The housing conditions in Brazilian urban areas during the 1990's. Brasília: IPEA, 2005. 27 p. (Texto para discussão, n. 1085). 
MORAIS, M. P.; CRUZ, B. O. Demand for housing and urban services in Brazil: a hedonic approach. Brasília: IPEA, 2003. 24 p. (Texto para discussão, n. 946).

MORAIS, M. P.; CRUZ, B. O.; OLIVEIRA, C. W. A. Residential segregation and social exclusion in Brazilian housing markets. Brasília: IPEA, 2003. 33 p. (Texto para discussão, n. 951).

O'FLAHERTY, B. Making room: the economics of homelessness. Cambridge, Massachusetts: Harvard University Press, 1998. 349 p.

PASTERNAK, S. O Desfio da mensuração. Brasília: Ministério das Cidades, Secretaria Nacional de Habitação, 2003. 20 p. Textos técnicos para subsidiar a formulação do programa nacional de integração urbana de assentamentos precários.

PARDO, C. The Chilean "tripartite" approach: loans, family savings and state subsidies. Housing Finance International, v. 15, n. 3, p. 32-41, Mar. 2001.

. Housing finance in Chile: primary and secondary mortgage financing. Housing Finance International, v. 14, n. 1, p. 15-25, Sep. 1999.

PAYERAS, M. Z. Housing finance in Mexico: current conditions and challenges. Housing Finance International, v. 14, n. 1, p. 32-40, Sep. 1999.

PEDROZO, E. As condições de propriedade nas regiões metropolitanas: considerações acerca da queda do número de imóveis financiados. Conjuntura da Construção. São Paulo, v. 4, n. 2, p. 4-6, jun. 2006.

PRADO, E. S.; PELIN, E. R. Moradia no Brasil: reflexões sobre o problema habitacional brasileiro. CBMM; FIPE, 1993. 85 p.

ROCHA LIMA JR, J. Instrumentos de investimento em empreendimentos habitacionais no Brasil: A questão Estrutural. São Paulo: EPUSP, 2004. 68 p. Boletim Técnico. Escola Politécnica da USP, Departamento de Engenharia de Construção Civil. BT/PCC/354.

RODRIGUES, V. B. Housing finance market in Brazil and the necessity of reform. Washington, D.C.: The school of business and public management, The George Washington University, 2000. $50 \mathrm{p}$. 
SANTOS, C. H. M; CRUZ, B. O. A dinâmica dos mercados habitacionais metropolitanos: aspectos teóricos e uma aplicação para a grande São Paulo. Brasília: IPEA, 2000. 26 p. (Texto para discussão, n. 713).

SECRETARIA NACIONAL DE HABITAÇÃO. Guia de orientações para a adesão dos Estados, Distrito Federal e Municípios ao Sistema Nacional de Habitação de Interesse Social - SNHIS e ao Fundo Nacional de Habitação de Interesse Social - FNHIS. Brasília: Governo Federal, Ministério das Cidades, 2006(a). 47 p.

Balanço nacional do setor habitacional - Política Nacional de Habitação. Brasília: Governo Federal, Ministério das Cidades, 2006(b). Disponível em: <http://www.cidades.gov.br $>$. Acesso em: 10 dez. 2006. (Apresentação para o Seminário Internacional : Housing Finance and Housing Subsidies: International Experiences and the Brazilian Housing Reform).

SILVA, M. O. S. Política habitacional brasileira: verso e reverso. São Paulo: Cortez, 1989. 199 p.

SERRA, M.V. et al. Affordable housing needs assessment methodology: adaptation of the Florida model to Brazil. Brasília: IPEA, 2005. 26 p. (Texto para discussão, n. 1083).

WERNA, E. et al. Pluralismo na habitação. São Paulo: Annablume, 2001. 300p. 